A Study of Fluvial Characteristics and Hydraulic Variables Middle Rio Grande New Mexico

GEOLOGICAL SURVEY WATER-SUPPLY PAPER 1498-F
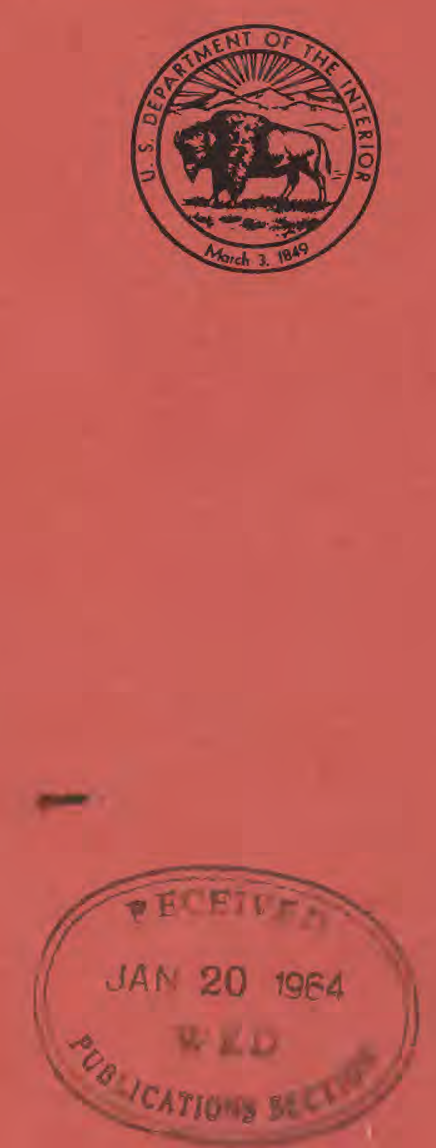


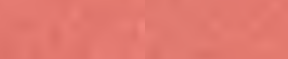

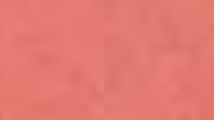

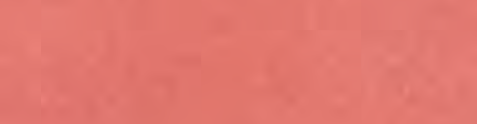

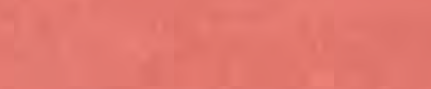

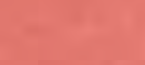

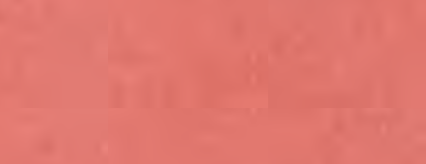

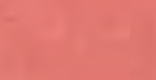

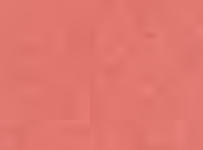

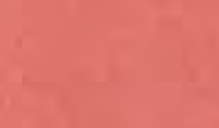
$\cos 20$

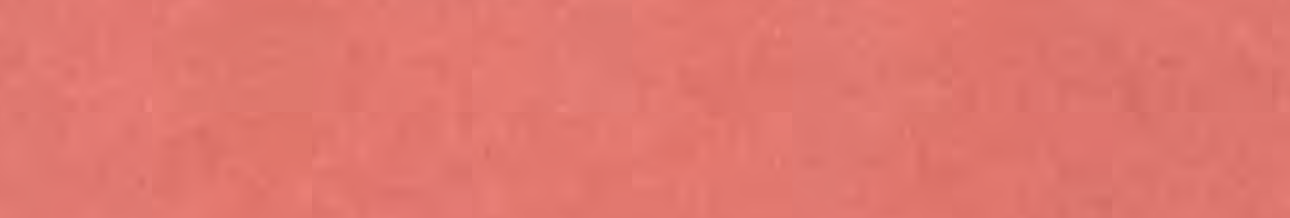

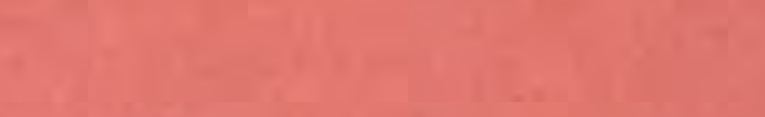

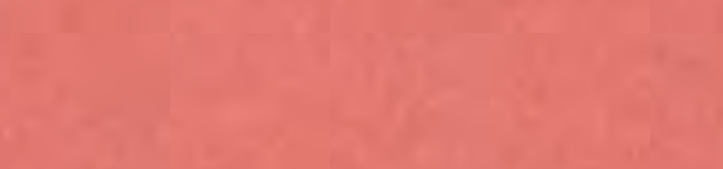

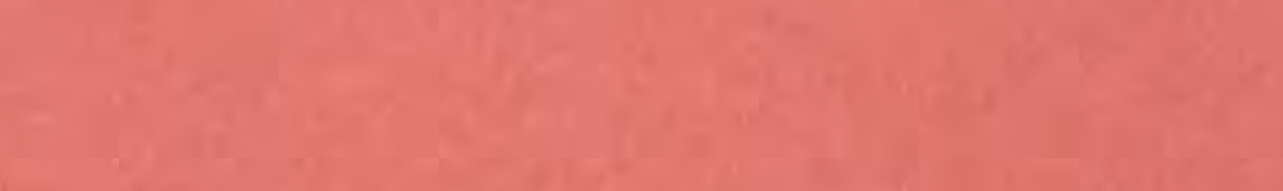

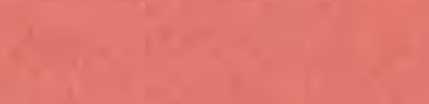

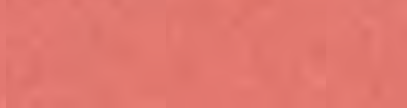

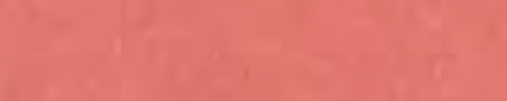

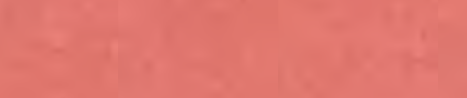

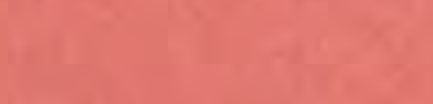

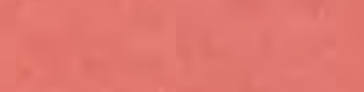

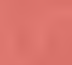




\section{A Study of Fluvial}

Characteristics and

\section{Hydraulic Variables \\ Middle Rio Grande \\ New Mexico}

By JAMES K. CULBERTSON and DAVID R. DAWDY

STUDIES OF FLOW IN ALLUVIAL CHANNELS

GEOLOGICALSURVEY WATER-SUPPLY PAPER 1498-F

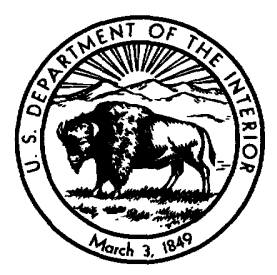




\section{UNITED STATES DEPARTMENT OF THE INTERIOR}

STEWART L. UDALL, Secretary

\section{GEOLOGIGAL SURVEY}

Thomas B. Nolan, Director 


\section{CONTENTS}

Page

Symbols_._.

Abstract.......... F1

Introduction

Purpose and scope

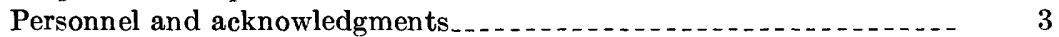

Geographic location and description of reaches.

Definitions . . . . . . . .

Measurement of hydraulic and sediment variables

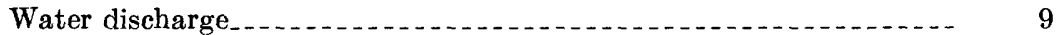

Concentration of suspended sediment

Suspended-sediment discharge

Bed elevation

Slope determinations...... 10

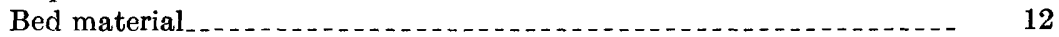

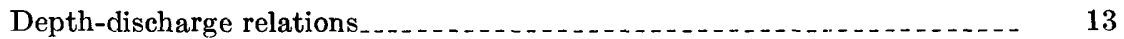

Depth-discharge relations at individual stations . _............. 14

Criteria for estimating regime of flow 18

Relation of Chezy $C$ to bed material

Other factors influencing roughness. 27

Relative roughness

Channel shape

Standard deviation of bed material . . . . . . . 28

Suspended-sediment concentration

Summary of other factors influencing roughness

Changes in bed elevation

Sediment transport functions

Relation of sediment transport to shear 36

Modified Einstein method ... 40

Bagnold theory

The Bagnold plot

Critical stress $\theta \approx 0.4 \ldots \ldots \ldots 7$

Characteristic applied tangential stress...

Total transport function, $\phi \ldots$

Comparison between modified Einstein and Bagnold

Conclusions and summary

Tables of basic data and computed parameters

Literature cited .

Index 


\section{ILLUSTRATIONS}

Figure 1. Location map of middle Rio Grande

2. Sketch map of Rio Grande near Bernalillo reach

3. Sketch map of Rio Grande near Belen, Casa Colorada reach

4. Rio Grande near Bernalillo reach, showing energy gradients

5-13. Relation of velocity to hydraulic radius.

5. Rio Grande near Bernalillo.

6. Casa Colorada reach near Belen . .

7. San Francisco riverside drain near Bernardo......

8. Rio Grande at Socorro . . . . . . . .

9. Rio Grande at San Antonio, January 1952-June 1953; October 1954-June 1955.

10. Rio Grande at San Antonio, July 1953-May 1954_.

11. Rio Grande at San Antonio, May-September 1954; July-September 1955 .

12. Galisteo Creek at Domingo .

13. Rio Puerco near Bernardo . . . . . . . . . . . . . . . 23

14. Garde's criteria for regimes of flow in alluvial channels...

15. Simons' criteria for regimes of flow in alluvial channels...

16. Variation of Chezy $C$ with median diameter of bed material.

17. Relation of velocity to hydraulic radius for Rio Grande at Cochiti. . . . . . . . . . .

18. Relation of velocity to hydraulic radius for Bernalillo sections $A-2$ and $F$

19. Changes in bed elevation during 1952 spring runoff, Bernalillo reach..................................

20. Changes in bed elevation during 1957 and 1958 spring runoff, Casa Colorada reach........................

21. Schematic diagram showing friction head loss in open channel flow

22-25. Relation of suspended sands to hydraulic radius.

22. Bernalillo sections $A-2$ and $F \ldots$

23. Bernalillo reach sections $A-2$ through $F$

24. Casa Colorada reach . . . .

25. Rio Grande at San Antonio . .

26. Comparison between computed total sediment loads at Bernalillo sections $A-2$ and $F_{\ldots} \ldots \ldots$

27. Relation between median diameter, $B_{s}$ and $B_{b} \ldots \ldots$

28. Bagnold plot of Rio Grande data..... 46

29. Bagnold relation for Casa Colorada reach

30. Comparison of Bagnold and modified Einstein computed total sands.

31. Comparison between modified Einstein and Bagnold total transport. 


\section{TABLES}

Page

TABLE 1. Energy gradients and water-surface slopes for the Rio Grande near Bernalillo reach, 1952.

F12

2. Energy gradients and water-surface slopes for Casa Colorada reach.

3. Median diameter of bed material, in millimeters, for the Rio Grande at Cochiti.

4. Median diameter and Chezy $C$ for the Rio Grande at Cochiti

5-18. Basic data and computed parameters.

5. Rio Grande at Otowi Bridge, near San Ildefonso..-

6. Rio Grande at Cochiti .

7. Galisteo Creek at Domingo

8. Rio Grande at San Felipe

9. Rio Grande at Angostura heading near Algodones.-

10. Rio Grande near Bernalillo, section $A-2 \ldots . . . . . .$.

11. Rio Grande near Bernalillo, sections $A, B, C, D, E_{\text {- - }}$

12. Rio Grande near Bernalillo, section $F_{\ldots} \ldots \ldots \ldots$

13. Rio Grande near Bernalillo, section $A-2$-runoff from tributary inflow

14. Rio Grande near Belen, Casa Colorada reach......

15. Rio Puerco near Bernardo.

16. Rio Grande near Socorro reach

17. Rio Grande at San Antonio

18. Rio Grande Floodway at San Marcial.

\section{2}

25

27

55

56

57

58

59

62

63

64

65

66

68

69

70

71 
SYMBOLS

\begin{tabular}{|c|c|c|}
\hline$y m b o l$ & Description & Units \\
\hline$A$ & Area of channel .... & $\mathrm{sq} f \mathrm{t}$ \\
\hline$b$ & Width of channel & $\mathrm{ft}$ \\
\hline$C$ & $\begin{array}{l}\text { Chezy coefficient of discharge, }\left(V / V_{*}\right) \sqrt{g .} \text { Sub- } \\
\text { script } 1 \text { and } 2 \text { indicate lower and upper regimes } \\
\text { respectively. }\end{array}$ & 0 \\
\hline$C_{\mathrm{m}}$ & $\begin{array}{l}\text { Concentration of measured suspended sediment } \\
\text { by weight. }\end{array}$ & ppm \\
\hline $\bar{C}$ & $\begin{array}{l}\text { Concentration of measured suspended sediment by } \\
\text { volume. }\end{array}$ & ppm \\
\hline$C_{\mathrm{T}}$ & $\begin{array}{l}\text { Concentration of measured suspended sands } \\
(>0.062 \mathrm{~mm}) \text { by weight. }\end{array}$ & ppm \\
\hline$d$ & Median diameter of bed material & $\mathrm{ft}$ \\
\hline$D$ & Average depth of flow & $\mathrm{ft} \cdot$ \\
\hline$f$ & Darcy-Weisbach friction factor equals $8\left(V_{*} / V\right)^{2}$ & 0 \\
\hline $\mathbf{F}$ & Froude number, $V / \sqrt{g D}$ & 0 \\
\hline$g$ & Gravitational constant $\ldots \ldots$ & ft per sec ${ }^{3}$ \\
\hline$h_{\mathrm{f}}$ & Friction head loss & ft \\
\hline$k$ & Constant & 0 \\
\hline$n$ & Manning's coefficient of roughness & ft $1 / 6$ \\
\hline$q_{\mathrm{s}}$ & Total sediment discharge in Bagnold equation. - & lb per sec per ft \\
\hline$Q$ & Discharge of water-sediment mixture & cu ft per sec \\
\hline$Q_{8}$ & Discharge of measured suspended sediment & tons per day \\
\hline$Q_{T}$ & Discharge of computed total sediment & tons per day \\
\hline$R$ & Hydraulic radius & $\mathrm{ft}$ \\
\hline$S$ & $\begin{array}{l}\text { Slope of water surface, assumed to equal energy } \\
\text { gradient, except where noted. }\end{array}$ & ft per ft \\
\hline$T$ & Water temperature & ${ }^{\circ} \mathrm{C}$ \\
\hline$V$ & Average velocity of flow & ft per sec \\
\hline$V_{*}^{\prime}$ & $\begin{array}{l}\text { Shear velocity which is } \sqrt{g D S} \text { or } \sqrt{\tau_{0} / \rho} \\
\text { Elevation above an arbitrary datum }\end{array}$ & $\begin{array}{l}\text { ft per sec } \\
\mathrm{ft}\end{array}$ \\
\hline$\gamma$ & Specific weight of water, 62.5 & lb per cu ft \\
\hline$\gamma_{s}$ & Specific weight of sediment, 165.6 & lb per cu ft \\
\hline$\Delta \gamma_{s}$ & $\begin{array}{l}\text { Difference between specific weights of sediment } \\
\text { and water, } 103 \text {. }\end{array}$ & lb per cu ft \\
\hline$\nu$ & Kinematic viscosity & sq ft per sec \\
\hline$\rho$ & Mass density of water, at $60^{\circ} \mathrm{F}$ equals $1.94 \ldots$ & slug per eu ft \\
\hline$\rho_{8}$ & Mass density of sediment, at $60^{\circ} \mathrm{F}$ equals $5.14 \ldots$ & slug per cu ft \\
\hline$\phi$ & $\begin{array}{l}\text { Bagnold transport rate function } \phi=q_{s} / b g \rho_{s} d \\
B_{b} \sqrt{\Delta \gamma s d / \rho}\end{array}$ & 0 \\
\hline$\tau_{0}$ & $\begin{array}{l}\text { Tractive or shear force developed on the bed, } \\
\gamma D S:\end{array}$ & lb per sq ft \\
\hline$\theta$ & $\begin{array}{l}\text { Bagnold shear function, or overall tangential stress } \\
\text { parameter }=\tau_{0} / \Delta \gamma_{s} d+D S C_{\mathrm{m}} / 2.65 d \text {. }\end{array}$ & 0 \\
\hline$\omega$ & $\begin{array}{l}\text { Fall velocity of sediment particles (median diam- } \\
\text { eter of bed material). }\end{array}$ & ft per sec \\
\hline
\end{tabular}




\title{
STUDIES OF FLOW IN ALLUVIAL CHANNELS
}

\section{A STUDY OF FLUVIAL GHARACTERISTICS AND HYDRAU- LIC VARIABLES, MIDDLE RIO GRANDE, NEW MEXICO}

\author{
By James K. Culbertson and David R. Dawdy
}

\begin{abstract}
Extensive data concerning water discharge and suspended-sediment transport for many sand-bed cross sections in the middle Rio Grande basin are analyzed. A discontinuity in the velocity-hydraulic-radius relations of these reaches is shown to occur, with velocity doubling for a constant depth. The roughness parameter, Chezy $C$, is relatively constant for discharges beyond the discontinuity, and mainly is a function of the size of bed material.

A discontinuity in the hydraulic-radius suspended-sand loads relation is shown to coincide with the discontinuity in depth discharge. Suspended-sand loads increase 8 to 10 times for a constant depth at the point of discontinuity.

The mechanics of scour and fill are studied, and it is indicated that contracted sections of a reach generally will scour on a rising stage and fill on the recession. The stream system apparently operates so as to maintain a constant energy gradient through a reach.

The suspended-sediment data for the middle Rio Grande are used to compute total loads according to the modified Einstein and the Bagnold methods. The modified Einstein method gives consistent results when applied to different cross sections of a single reach. The Bagnold method apparently predicts a correct shape for the shear-transport relation, but it is not as suited to field use at this time as is the modified Einstein method.
\end{abstract}

\section{INTRODUCTION}

\section{PURPOSE AND SCOPE}

The purpose of this report is to present interrelations between hydraulic radius, median size of bed material, channel-bed roughness, flow regime, mean velocity, and sediment transport for flow in sand channels of the middle Rio Grande in New Mexico. Data used were collected during the period 1952 to 1959 as part of a cooperative program between the U.S. Geological Survey and the U.S. Bureau of Reclamation to study sediment transport in the middle Rio Grande.

Observations were made at eight stations on the main stem of the Rio Grande. The stations presented are in that reach of the Rio Grande from Otowi Bridge near San Ildefonso to San Marcial, N. 


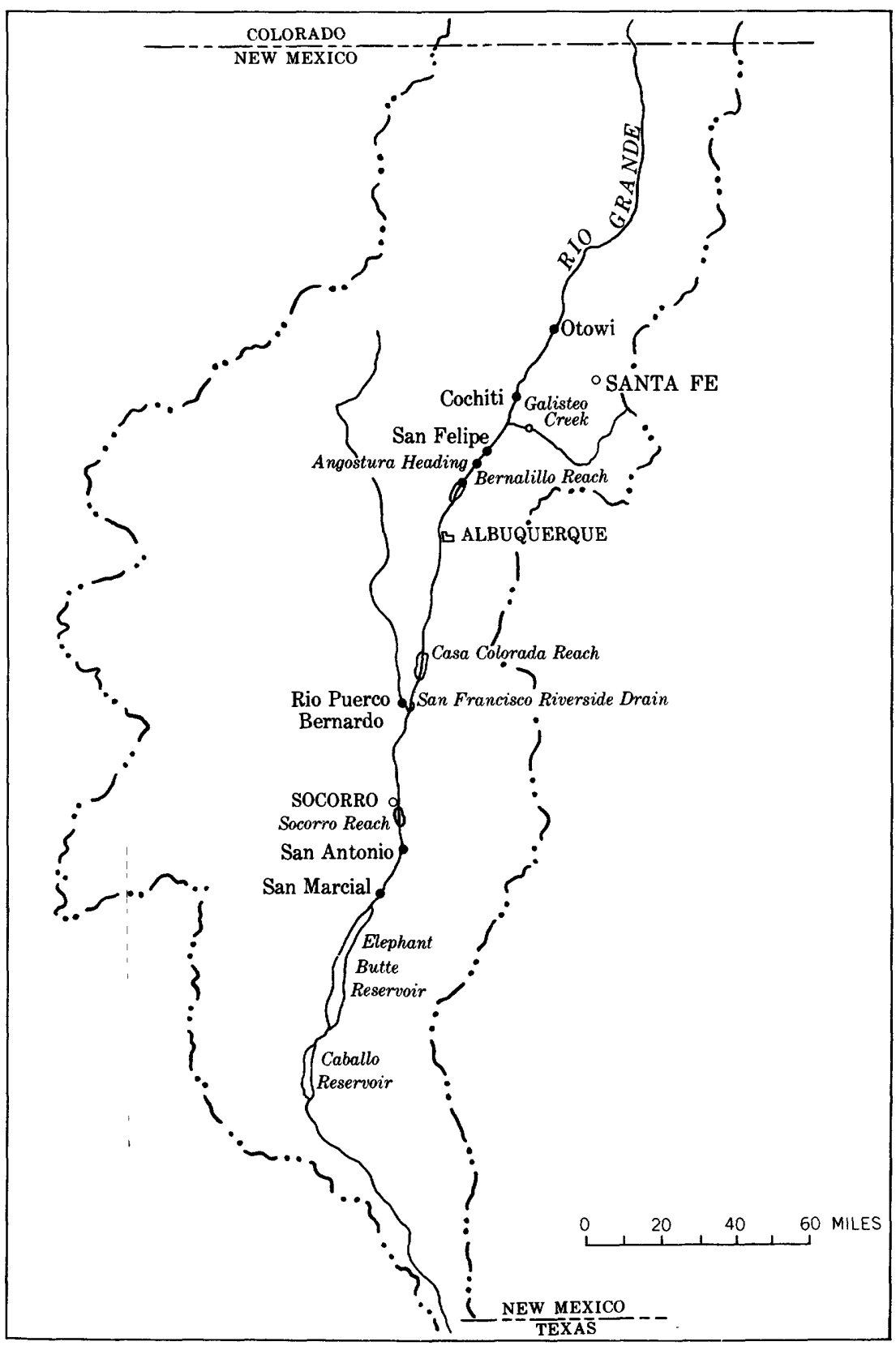

Figure 1.-Location map of the middle Rio Grande. 
Mex., approximately 180 miles (fig. 1). The study sites at three stations were reaches of approximately $1 \frac{1}{2}$ miles each. The Rio Grande near Bernalillo reach includes 7 sections, the Rio Grande near Belen, Casa Colorado reach, 10 sections, and the Rio Grande near Socorro reach, 4 sections. Rates of flow ranged from $2,000 \mathrm{cfs}$ (cubic feet per second) to $10,000 \mathrm{css}$; frequencies of discharge being from that equaled or exceeded 50 percent of the time to that equaled or exceeded 10 percent of the time.

Most of the observations listed in this report represent spring runoff from the headwaters of the Rio Grande in Colorado, some minor tributaries in northern New Mexico, and runoff from the Rio Chama. The Rio Chama is the largest contributor of tributary inflow above the Rio Grande at Otowi Bridge station.

Several measurements representing flow from the Rio Puerco are shown for the Rio Puerco near Bernardo, the Rio Grande near Socorro, and the Rio Grande at San Antonio stations. Some storm runoff data for the Galisteo Creek at Domingo also are included.

Data observed for most of the stations include (1) stream depths and velocities, (2) samples of suspended sediment, (3) samples of the bed material, (4) water temperature, and (5) water-surface slope. Slopes are not available for all observations.

Hydraulic characteristics at each station are discussed, and flow regime based on discontinuities in the stage-discharge relation and visual observation of water surface appearance are noted. Sedimenttransport characteristics are described for each station and related to hydraulic variables and regimes of flow. Most of the total-load computations represent upper-flow regimes, that is, plane bed, standing wave, or antidune bed configuration; however, several computations are shown for lower-regime flows or dune bed configuration. The relation between $V_{*} / \omega$ and $V_{*} d / \nu$ is used to compare forms of bed roughness found in the. Rio Grande with those found in flume studies. The relation between the roughness parameters, Manning's $n$ and Chezy's $C$, and median diameter of bed material is shown to be well defined for stations studied in the Rio Grande basin.

Total sediment loads are computed by using the modified Einstein method and the Bagnold method. Also, field data are used to test the interrelation of Bagnold's total-transport and shear functions.

\section{PERSONNEL AND ACKNOWLEDGMENTS}

This report was written under the supervision of J. M. Stow, district chemist, Albuquerque District, Quality of Water Branch. Field and laboratory work was under the supervision of W. G. Bratschi, succeeded by J. K. Culbertson, hydraulic engineer, Geological Survey. F. C. Ames and G. L. Oakland of the Geological Survey assisted 690-231 0-63-2 
materially in setting up the field investigations. R. W. Fife, chief of the Hydrology Section, and E. L. Pemberton, head of the Sedimentation Section, both of the Albuquerque Bureau of Reclamation Office planned and supervised the data collection program for the Bureau at field level.

C. F. Nordin, Jr., hydraulic engineer, Geological Survey, aided materially in the planning and beginning of this report.

\section{GEOGRAPHIC LOCATION AND DESCRIPTION OF REACHES}

The Otowi Bridge station is located at the lower end of an alluvial reach, which includes the lower Rio Chama (fig. 1). Alluvium apparently has accumulated in the Rio Grande between the mouth of the Chama and the Otowi Bridge location as the result of flow from the Rio Chama. Immediately downstream from the Otowi station the Rio Grande enters a narrow gorge, which confines the river channel. Although no data are available, it is believed that little or no aggradation or degradation occurs within the reach between the Otowi Bridge and Cochiti stations. Data for Otowi Bridge are shown in table 5.

At Cochiti the river channel and flood plain widen considerably and the river channel becomes characteristic of that of a sand-bed stream. However, large gravel and rock are predominant bed materials at discharges higher than the approximate median frequency discharges at this station, which is located approximately 1 mile below the Cochiti diversion dam. The dam does not appear to trap any appreciable sand loads. Data for the Cochiti station are shown in table 6.

Eight miles below Cochiti the Galisteo Creek empties into the Rio Grande. The Galisteo is a large contributor of sediment to the Rio Grande. Galisteo Creek did not contribute to the spring runoff flows that are described in this report; however, some data on flashflood events are presented (table 7).

The San Felipe station is approximately 7 miles downstream from the mouth of Galisteo Creek. Tonque Arroyo empties into the Rio Grande immediately upstream from the San Felipe station. This arroyo runs only infrequently and did not contribute to the spring runoff events covered in this report. The river channel at the San Felipe station is narrow, being confined by a volcanic talus slope on the right bank and fairly stable clay banks on the left. Velocities are relatively high, and bed material in the sand range, which is brought in by Galisteo Creek and Tonque Arroyo, apparently is moved on past the station. There is little evidence of general aggradation at this site. Samples of bed material taken at the San Felipe station during high discharges showed sparse quantities of sand-size particles. Data for the San Felipe station are shown in table 8. 
Angostura diversion dam is approximately 5 miles downstream from the San Felipe station and forms the headworks for the Albuquerque main canal. Data were collected in the Rio Grande above the heading, in the settling basin immediately below the heading, in the wasteway return to the river, and in the Albuquerque main canal (table 9) as part of a study by the U.S. Bureau of Reclamation to determine the trap efficiency of the settling basin.

The Jemez River empties into the Rio Grande, 8 miles downstream from the San Felipe station. The Jemez River brought large sediment loads into the Rio Grande before the completion of Jemez Canyon Reservoir, which is approximately $1 \frac{11}{2}$ miles upstream from the mouth. Operation of this reservoir controlled all spring runoff from the Jemez River during the period covered by this report, and only minor releases were made during periods of observations. Approximately $500 \mathrm{cfs}$ was released for a short period on June 18, 1959 . The rise in suspended-sediment concentration can be noted in the data table for the Bernalillo section $A-2$ station (table 10 ).

The Rio Grande near Bernalillo station, referred to in this report as Bernalillo section $A-2$, is located at a comparatively narrow point 8 miles downstream from the mouth of Jemez River. The right bank is a high bluff composed of a calcareous sandstone. The left bank consists of a silty clay that is stabilized by salt cedar, cottonwoods, and range grasses. Width of the river channel at this point has remained at 270 feet \pm 3 feet at all discharges above about $1,000 \mathrm{cfs}$ for several years. The Bernalillo section $F$ is 8,240 feet downstream from the Bernalillo section $A-2$. Section $F$ is comparatively wide with varying widths for all discharges. A section of this report is devoted to the observed differences in hydraulic and fluvial characteristics between these two stations (tables 10-13). A sketch map of the Bernalillo reach is shown in figure 2.

The next stations in downstream order below the Bernalillo stations are (1) Rio Grande at Albuquerque, (2) Rio Grande at Belen, and (3) Rio Grande near Bernardo. These three stations are measured from bridges. No data for these stations are discussed, because the hydraulic conditions caused by the bridge structures are extremely complicated. The Bernardo station is approximately 65 miles downstream from the Bernalillo station. There is no large tributary inflow in this 65 mile reach.

Approximately 7 miles downstream from the Rio Grande at Belen is the Casa Colorada reach. This reach of about $3 \frac{11}{2}$ miles is of particular interest because of recent channel rectification work by the Bureau of Reclamation. Kelner jetties were used extensively through this reach in an effort to realine the river channel and to control bank erosion. A great deal of effort has gone into a thorough study of the 


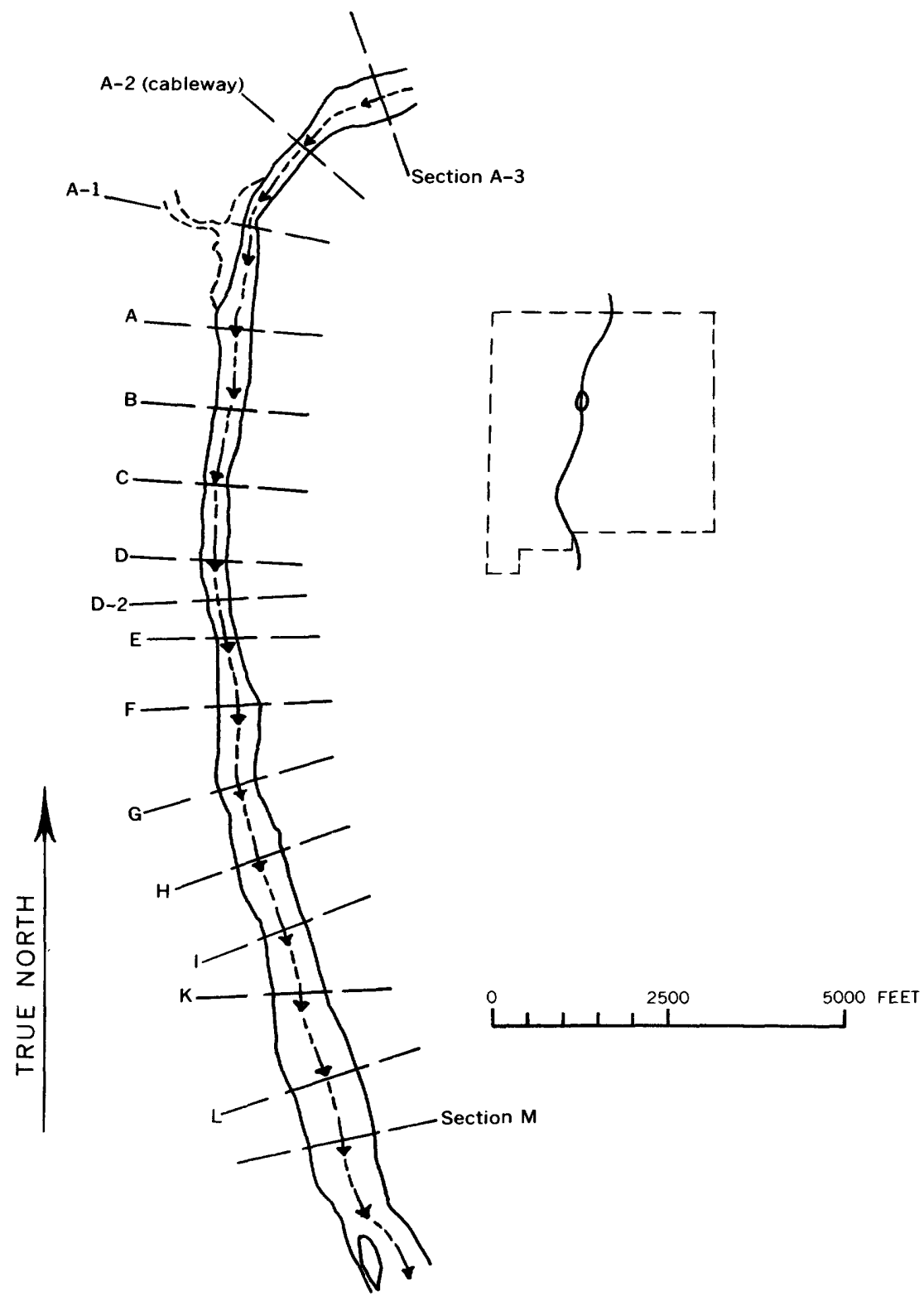

Figure 2.-Sketch map of the Rio Grande near Bernalillo reach.

reach before and after installation of the jetties. A model of the entire reach was constructed for study at the hydraulic laboratory of the Bureau of Reclamation in Denver, Colo. Total-load data and other hydraulic measurements were collected throughout the 
upper $1 \frac{1}{2}$ miles in the prototype reach by the Geological Survey. Hydraulic and sediment variables are shown in table 14. A sketch map of the Casa Colorada reach is shown in figure 3.

Three miles downstream from the Rio Grande near Bernardo station is the mouth of the Rio Puerco. The Rio Puerco has the largest tributary drainage area to the Rio Grande in New Mexico and yields great quantities of sediment. Sediment concentrations in excess of $400,000 \mathrm{ppm}$ (parts per million) by weight have been recorded at the Rio Puerco near Bernardo station. Some data are shown for this station in table 15.

Approximately 9 miles downstream from the mouth of the Rio Puerco is the mouth of the Rio Salado. The Rio Salado is similar to

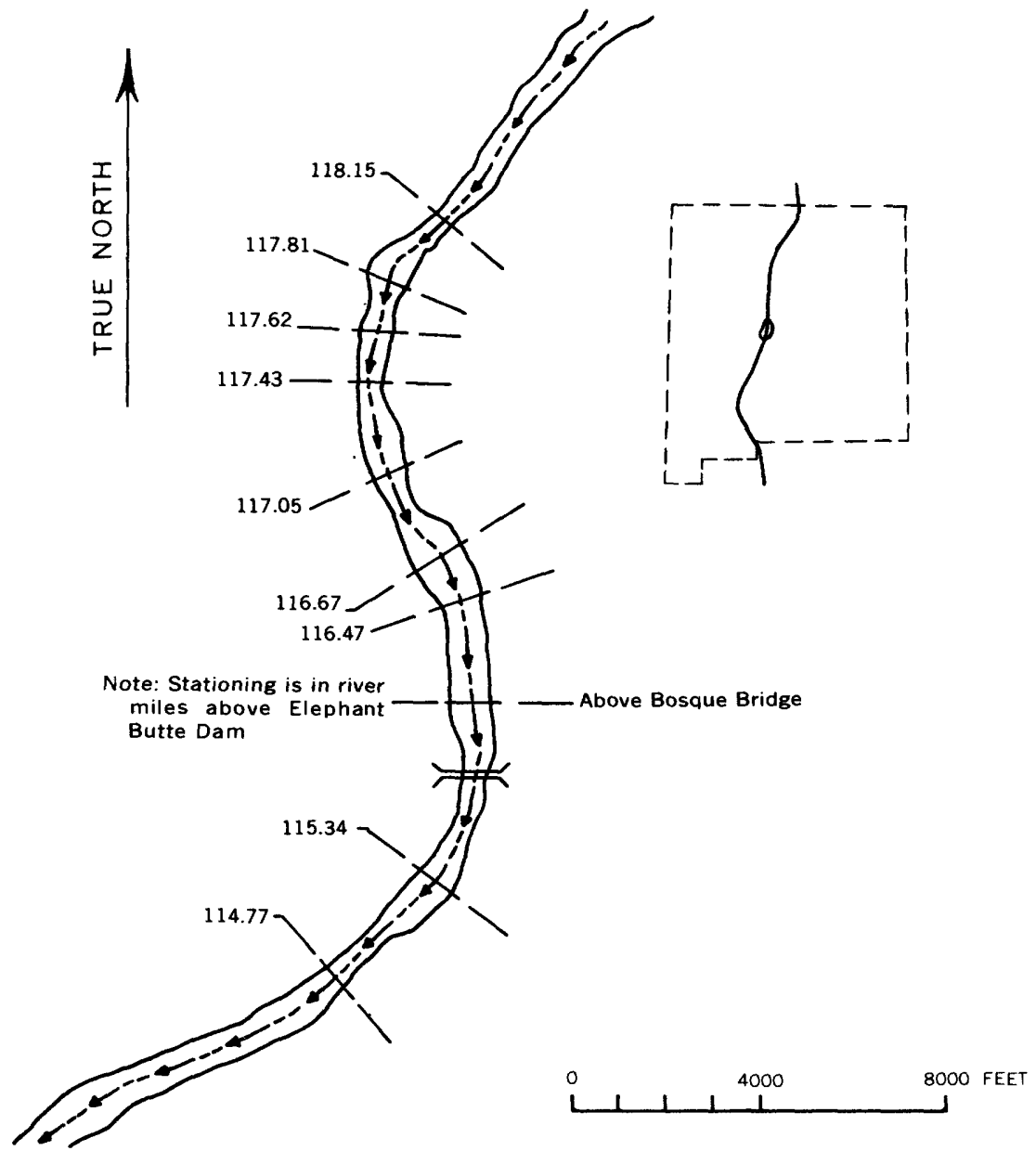

Figure 3.-Sketch map of the Rio Grande near Belen, Casa Colorada reach. 
the Rio Puerco in that it is an intermittent stream yielding large quantities of sediment. Two miles below the Rio Salado is San Acacia diversion dam. No data are presented for the Rio Grande at San Acacia station, which is 0.7 mile downstream from the diversion dam.

Some data are presented in table 16 for a 1-mile reach of the Rio Grande near Socorro. This reach is about 16 miles downstream from the San Acacia station. There is no station near this reach of the Rio Grande.

The next station downstream from Socorro reach is the Rio Grande at San Antonio. San Antonio is about 28 river miles from the San Acacia station. Data are presented for this station in table 17.

The Rio Grande at San Marcial station is another 21 miles below San Antonio and is the southernmost station covered by this report. Data for the Rio Grande at San Marcial station are shown in table 18.

\section{DEFINITIONS}

Bedload consists of particles that mainly are in continuous contact with the bed. Movement of these particles occurs by rolling, sliding, or jumping along the bed.

Suspended-sediment discharge is computed from total water discharge and the concentration of suspended-sediment samples.

Regime of flow includes those flows for which the bed configurations are similar.

A sand-bed channel is one in which there is an unlimited supply of material in the sand sizes on the bed of the stream, and the median diameter of this bed material does not vary appreciably with depth to known maximum scour or with change in water discharge.

A sand-gravel channel is one in which the supply of sand-size material on the streambed is limited, and median diameter varies appreciably with discharge, ranging from sand sizes through coarse gravel sizes.

Sediment-transport functions give the rates at which water discharges of any magnitude in a given channel will transport sediment particles of sizes which are found in the streambed.

Suspended load is that part of the total sediment load that is in equilibrium with a normal fluid stress and for which the grains are supported entirely by the fluid stresses. Those particles in colloidal suspension are also part of the suspended load.

Total-sediment discharge is the rate of movement or discharge of the suspended load plus the bedload.

Unmeasured-sediment discharge is the difference between the totalsediment discharge and the suspended-sediment discharge. 
Fine-material load is that part of the suspended load that consists of grain sizes finer than those found in appreciable quantities in the bed. Fine-material load is sometimes referred to as wash load.

\section{MEASUREMENT OF HYDRAULIC AND SEDIMENT VARIABLES}

In order to give the reader a better understanding of some of the data presented herein, some of the measured variables will be discussed and the methods of field measurement described.

\section{WATER DISCHARGE}

The term "water discharge" actually means discharge of the watersediment mixture and includes all dissolved and suspended matter being transported by the fluid. However, only mean depth, mean velocity, and width are used to compute water discharge.

\section{CONCENTRATION OF SUSPENDED SEDIMENT}

Suspended-sediment concentrations were computed from samples taken at the same cross section used in the water-discharge measurement. Samples were taken using US DH-48 or US D-49 sediment samplers. These samplers are designed to collect a representative sample of the water-sediment mixture from the surface to about 0.3 foot from the streambed. Samplers and sampling techniques are described in reports 1 and 6 (Subcommittee on Sedimentation, Federal Inter-Agency River Basin Committee 1940, 1952). All samples were integrated vertically and were taken at equal intervals of width and equal transit rates in the cross section, thus giving discharge-weighted mean concentrations in parts per million by weight. Particle-size distributions were determined for all samples by the visual accumulation tube-pipette method of analysis.

\section{SUSPENDED-SEDIMENT DISCHARGE}

Measured suspended-sediment discharge is the product of total water discharge in cubic feet per second, mean sediment concentration in the sampled zone in parts per million, and a conversion factor that converts the result to a rate in tons per day. That is, all sediment discharge values, both suspended and total are shown as rate of transport.

\section{BED ELEVATION}

Bed elevations shown in the tables of data for each station are relative to the existing station datum or to a temporary datum established at the location. Mean depths are subtracted from the datum or gage height to obtain bed elevation. For some stations, a constant was added to the gage height in order to obtain positive values. 


\section{SLOPE DETERMINATIONS}

Slope is the variable most difficult to measure in the field. Watersurface slopes and energy gradients over short reaches on sandchannel streams vary considerably when measured at different times. Use of instantaneous measurements in computing various parameters involving slope tends to introduce scatter into any plot that concerns those parameters.

Similar fluctuations of instantaneous slope measurement are experienced in laboratory flumes with sand beds. Over a period of several hours, a flume considered as flowing in equilibrium may have instantaneous slope values varying by 50 percent. A U.S. Geological Survey research team at Colorado State University has used a recorder attached to a differential bubbler gage to measure slope continuously (Simons and others, 1961). Although fluctuations are sizable, the time average has been found to be consistent if a sufficiently long time base is used.

Although the reaches used on the Rio Grande were on the order of 1,000 feet long, it was hypothesized that instantaneous measurements of water surface slope were not significant, but could be used to determine an average slope for the reach.

Three methods were used for testing this hypothesis. First, at Bernalillo for the 1952 data, a plot of energy gradients was used to determine whether an average slope could be fitted to various longer reaches through several sections for all six runs. (See fig. 4.) It was found that a slope of about $0.00095 \mathrm{ft}$ per $\mathrm{ft}$ could be fitted through sections $A-2$ to $A-1$ and $E$ to $G$, and of ten through longer reaches. This seemed to indicate that the average slope value might be used to compute variables for several sections and perhaps be more accurate than using the instantaneous measured values. Second, the average of the instantaneous values of slope for each station and reach was compared with the slope as picked from a topographic map. These slopes agreed quite well, which indicated that the variations were about a mean value for a much longer reach than that normally used between sections. Third, for several stations, the variation in plots involving slope, such as those of shear and Chezy $C$, was compared when computed for instantaneous values and for average values. The average values gave much less scatter to the plots, indicating that the average values were more meaningful than the instantaneous values in describing effects of the slope acting upon the system.

In addition a comparison was made of energy gradients and water surface slopes for the 1952 Bernalillo runs between reaches $A-2$ to $A$, a distance of 2,840 feet and $F$ to $H$, a distance of 2,160 feet. The reach from $A-2$ to $A$ is narrow and that from $F$ to $H$ is wide. The 


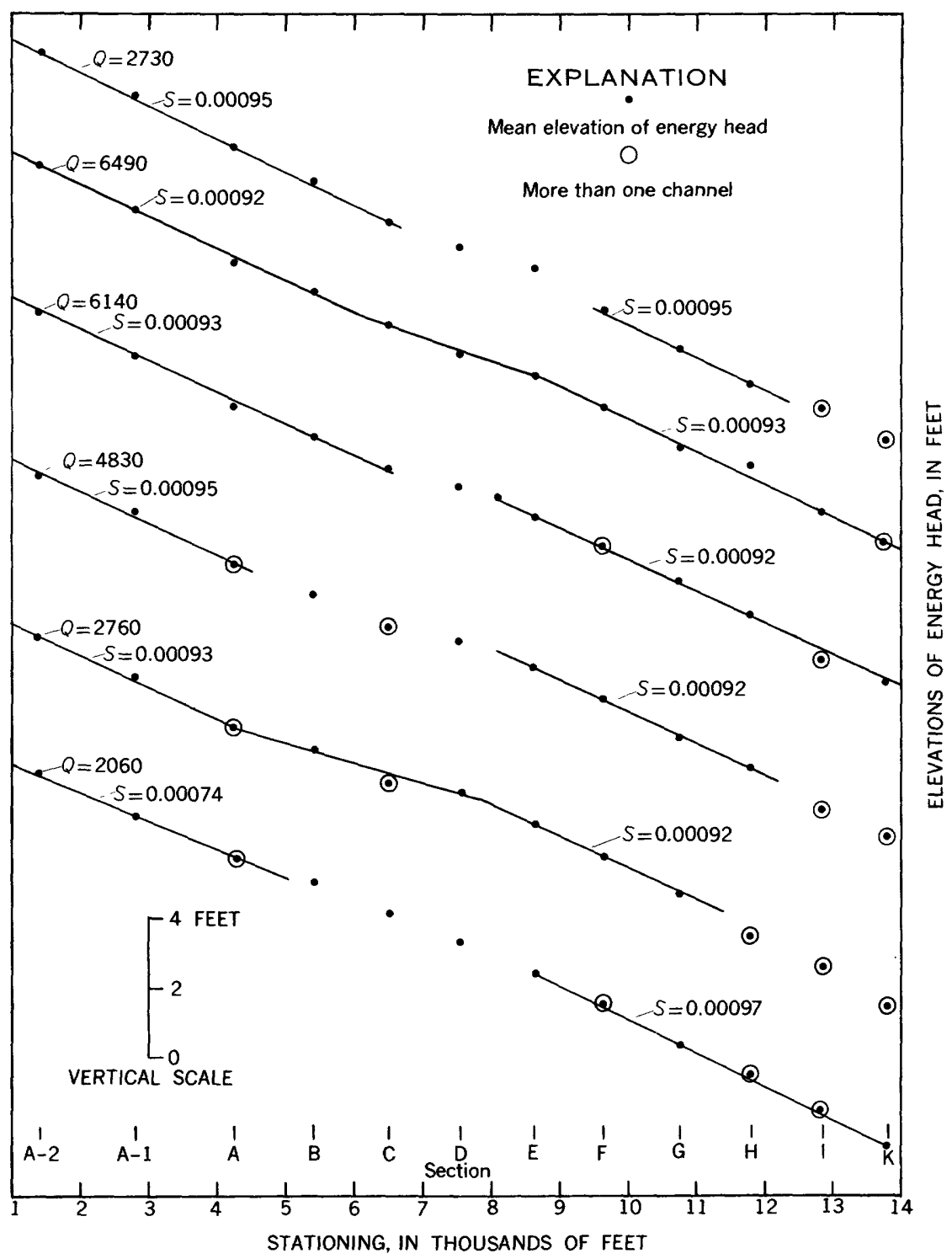

Figure 4.-Rio Grande near Bernalillo reach, showing energy gradients.

energy gradient was computed by correcting the water-surface fall for the change in velocity head as computed by the formula, $h_{e}=V^{2} / 2 g$. Using the readings observed at these cross sections only, and giving no weight to other sections, it was found that the average water-surface slopes and energy gradients for the two reaches were in close agreement. The results are given in figure 4 and table 1. 
TABLE 1.-Energy gradients and water-surface slopes for the Rio Grande near Bernalillo reach, 1952

\begin{tabular}{|c|c|c|c|c|}
\hline \multirow{2}{*}{ Date } & \multicolumn{2}{|c|}{ Sections $A-2$ to $A$} & \multicolumn{2}{|c|}{ Sections $F$ to $H$} \\
\hline & Energy drop & $\begin{array}{l}\text { Water-surface } \\
\text { fall }\end{array}$ & Energy drop & $\begin{array}{c}\text { Water-surface } \\
\text { fall }\end{array}$ \\
\hline $\begin{array}{l}\text { April } 25 \\
\text { April } 12 \\
\text { June } 17 \\
\text { June } 20 \\
\text { June } 26 \\
\text { July } 24\end{array}$ & $\begin{array}{l}\text { 2. } 67 \\
2.73 \\
2.73 \\
\text { 2. } 53 \\
\text { 2. } 60 \\
\text { 2. } 37\end{array}$ & $\begin{array}{l}2.60 \\
2.63 \\
2.67 \\
2.66 \\
2.63 \\
2.46\end{array}$ & $\begin{array}{l}\text { 2. } 15 \\
\text { 1. } 74 \\
\text { 1. } 97 \\
\text { 1. } 96 \\
\text { 2. } 31 \\
\text { 2. } 06\end{array}$ & $\begin{array}{l}\text { 2. } 09 \\
\text { 1. } 80 \\
1.69 \\
\text { 1. } 78 \\
2.34 \\
2.07\end{array}$ \\
\hline $\begin{array}{l}\text { Average } \\
\text { Average slope }\end{array}$ & $\begin{array}{l}\text { 2. } 605 \\
.00092\end{array}$ & $\begin{array}{l}\text { 2. } 608 \\
.00092\end{array}$ & $\begin{array}{l}\text { 2. } 032 \\
.00094\end{array}$ & $\begin{array}{l}\text { 1. } 962 \\
.00091\end{array}$ \\
\hline
\end{tabular}

Similar computations were made at the Casa Colorada reach. The results were as follows:

Average energy gradients and water-surface slopes agree surprisingly well, both at a reach and between reaches. This should be somewhat expected, however, because channel-control conditions should prevail at all times in a sand-channel stream, and fluctuations of both water-surface slopes and energy gradients should be about the same stationary mean value. As a result of these studies, average measured water-surface slopes for the range of discharge observed for each station were determined and used for computations of all parameters in this report.

TABLE 2.-Energy gradients and water-surface slopes for Casa Colorada reach

\begin{tabular}{|c|c|c|}
\hline Reach & Energy gradient & $\begin{array}{l}\text { Water-surface } \\
\text { slope }\end{array}$ \\
\hline $\begin{array}{l}116.87-116.47 \\
116.67-116.47 \\
117.62-117.43 \\
117.81-117.43\end{array}$ & $\begin{array}{r}0.00085 \\
.00081\end{array}$ & $\begin{array}{r}0.00082 \\
.00078 \\
.00087 \\
.00085\end{array}$ \\
\hline
\end{tabular}

BED MATERIAI

It will be shown in this report that particle size of bed material at a given cross section is a very important variable in determining sediment-transport rate, form of bed roughness, and resistance to flow. The median diameter, $d$, is used in this report as the primary variable representing bed material.

This report deals mainly with the sand-bed channels of the Rio Grande. Sand is that material larger than $0.062 \mathrm{~mm}$ and finer than $2.00 \mathrm{~mm}$ in diameter. It is the authors' belief that the median diameter of bed material for a sand-bed channel, as defined in this report, usually does not exceed $0.60 \mathrm{~mm}$. For such a channel samples 
of bed material taken throughout a wide range in discharge show no large variation of median diameter.

Most of the stations in this report can be considered as having sand-bed channels, the exceptions being the sand-gravel channels of the Rio Grande at Otowi Bridge, Cochiti, and San Felipe stations. The Rio Grande near Bernalillo station is an excellent example of a sand-bed channel. A great number of bed-material samples have been collected and analyzed at this station and show very little deviation from a median diameter of $0.30 \mathrm{~mm}$. For instance, of 56 individual bed-material samples collected near Bernalillo in 1958, the median diameters for 48 samples range only from 0.20 to 0.40 $\mathrm{mm}$, whereas for 53 samples the range is 0.20 to $0.48 \mathrm{~mm}$. The largest $d$ of the 56 observations was $1.15 \mathrm{~mm}$, whereas the only one below $0.20 \mathrm{~mm}$ was $0.075 \mathrm{~mm}$.

The stations downstream from Bernalillo are similar in that the medians of bed-material samples vary conservatively. Upstream tributary flows often will leave a thin film of finer material in the bed. This fine-grained sediment apparently produces little or no prolonged changes in median diameter, because it usually is picked up by a subsequent increase in dischage in the main channel.

The Rio Grande at Cochiti station is a good example of a nonsandbed channel, or a sand-gravel channel. During two high-water periods of May and June 1957 and 1958, samples of bed material show the median diameter to range from 0.13 to $33.0 \mathrm{~mm}$, and size distributions of the material show bimodal characteristics.

\section{DEPTH-DISCHARGE RELATIONS}

A discontinuity occurs in the depth-discharge relation of many sand-bed stations in the middle Rio Grande. For a given depth, there may be no unique relation with velocity. This is due to the fact that the form of bed roughness and, hence, resistance to flow are a function of fluid, sediment, and flow characteristics.

Laboratory studies (Simons and others, 1961) have been used to define the various regimes of flow in terms of configuration of the sand-bed channel as follows:

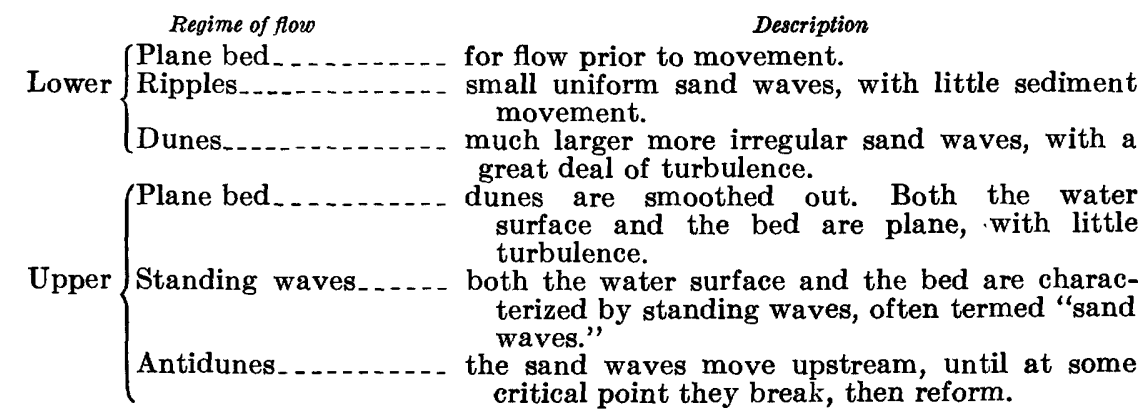


The discontinuity occurs between the dune regime and the plane bed regime. The roughness of the channel in the lower regimes is about twice the roughness for upper regimes. For upper regimes roughness is principally a grain roughness, whereas for lower regimes there is both grain and form roughness.

The general approach to the determination of roughness is through the Chezy formula

$$
V=C \sqrt{R S}
$$

which means that the velocity at a cross section varies as the square root of the hydraulic radius, if slope and roughness are constant. For the wide shallow channels of the Rio Grande, depth and hydraulic radius are almost identical; therefore mean depth could be substituted for hydraulic radius in the Chezy formula. However, both theory and experience on relatively deeper channels indicate that hydraulic radius is preferable to depth as a parameter to define the mean velocity of a stream. The usual adaptation to rigid channels of this relation is the well known Manning's formula, where

$$
C=\frac{1.5}{n} R^{1 / 6} \text {. }
$$

In this relation, velocity varies as the two-thirds power of hydraulic radius, if slope and Manning's $n$ are constant. Because, as stated earlier, slope can be considered as a constant with only statistical variation, a comparison of the variation of velocity with hydraulic radius can be used to study the variation of roughness, and, if roughness is constant, to determine whether Chezy $O$ of Manning's $n$ is the better parameter for representation of roughness. Once the roughness parameter at a station is defined, then its variation among stations can be related to physical properties.

Assuming all sands are of about the same specific weight, and that temperature variations are averaged out in the relation at each station, the parameters most likely to explain the variation between stations would be the characteristics of the bed material.

\section{DEPTH-DISCHARGE RELATIONS AT INDIVIDUAL STATIONS}

If the Chezy $C$ is used as the roughness factor, the roughness appears to be approximately constant at each main stem station from Bernalillo to San Antonio for all measurements of flows above the discontinuity that were studied for this report. Figures 5 to 8 show plots of hydraulic radius and velocity for Rio Grande near Bernalillo, N. Mex., the Casa Colorado and Socorro reaches, and the San Fran- 


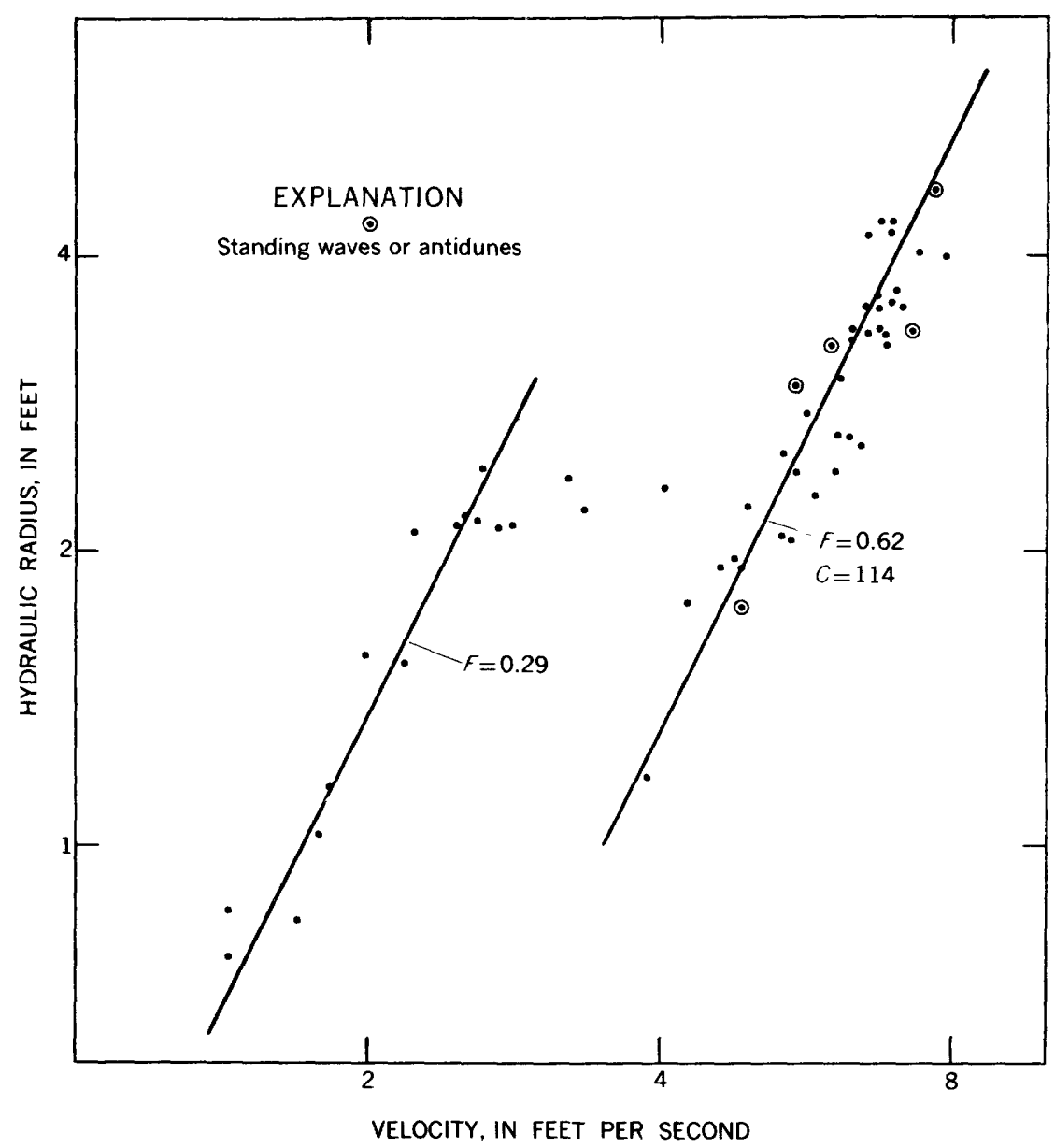

FIGURE 5.-Relation of velocity to hydraulic radius for Rio Grande near Bernalillo. .

cisco riverside drain near Bernardo, N. Mex. For each station plot, a line has been drawn representing the relation

$$
V=k r^{1 / 2}
$$

Thus, since-

$$
V=C R^{1 / 2} S^{1 / 2}
$$

then-

$$
C=k / S^{1 / 2} \text {. }
$$

The stations from Bernalillo downstream are quite similar in that the depth-discharge relations have a discontinuity, an average Chezy $C$ can be assumed for the upper regime, and the standing waves and antidunes plot among the other upper regime flows. The San Antonio 


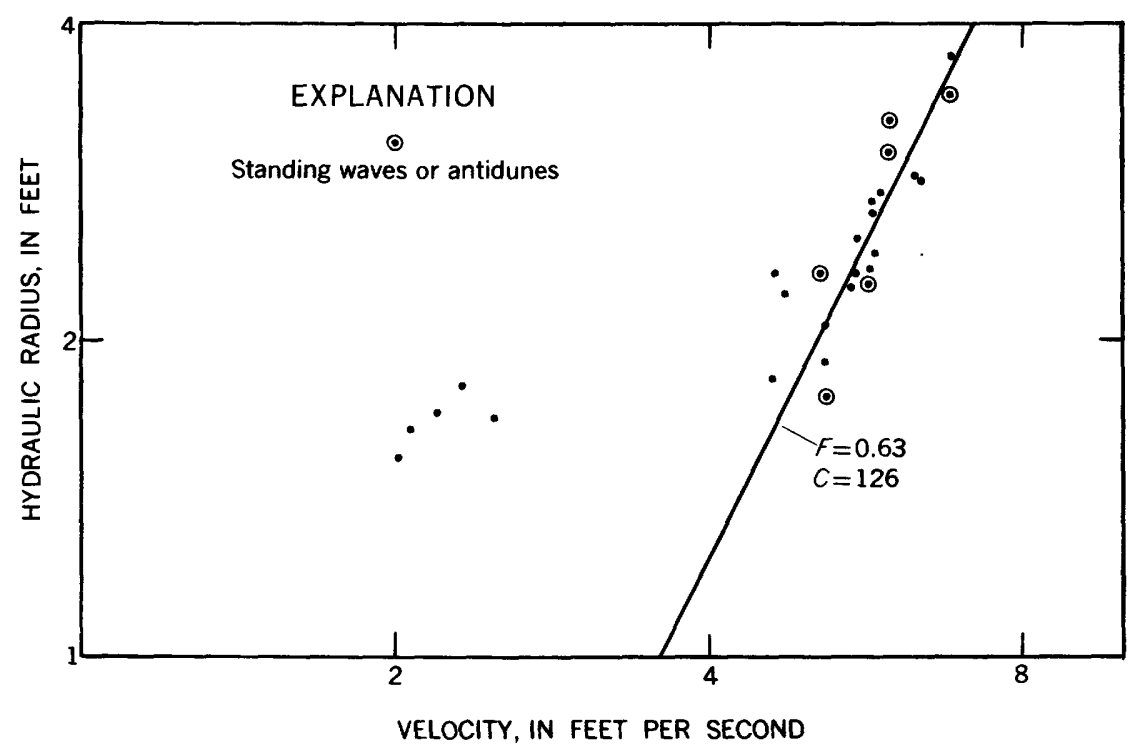

FIGURE 6.-Relation of velocity to hydraulic radius for Casa Colorada reach near Belen.

station is different, however, in that there seem to be definite shifts in the relation, after the discontinuity, of velocity to hydraulic radius. It has shown evidence of three separate relations during the period studied (figs. 9-11). These major shifts have occurred when the stream has been completely dry.

Because the upper regime measurements shown in figures 10 and 11 plot about an average of 25 percent greater than the $R V$ curve shown in figure 9, either the slope must increase or the bed-material size decrease, if Chezy $C$ is assumed constant for a given bed material. Whether the shifts in depth-discharge relation are the result of changes in energy slope is not known, but the bed material has remained practically constant.

Simons (oral communication) stated that in flume studies there is a consolidation of the bed whenever the flume is dry. This may be a partial explanation of the shifts in the hydraulic radius-velocity relation at San Antonio, but there is no explanation as to why this effect is selectively applicable at this one reach. In addition, San Antonio is downstream from the Rio Puerco and thus receives large quantities of fine material in suspension. This also may have some effect on the bed consolidation and thus on the shifts at San Antonio.

For the station at San Marcial, only those measurements with flows noted as being in standing waves or antidunes were used to define the Chezy $C$ for upper regime flows. The station is immediately upstream from a bridge, and local scour at times extends to the 
measuring section, changing the apparent characteristics of the depth-discharge relation.

Similar plots for the two tributary stations, Galisteo Creek at Domingo and Rio Puerco near Bernardo, are shown in figures 12 and 13. For Galisteo Creek all measurements for which the average velocity was greater than $4 \mathrm{fps}$ (feet per second) were used to define the curve after the discontinuity. This included all measurements above $400 \mathrm{cfs}$. For Rio Puerco it was found that the change in regime often did not occur until after the peak gage height. This may be due to the large concentration of clay which is deposited upon the bed during the recession and later hardens into an armoring

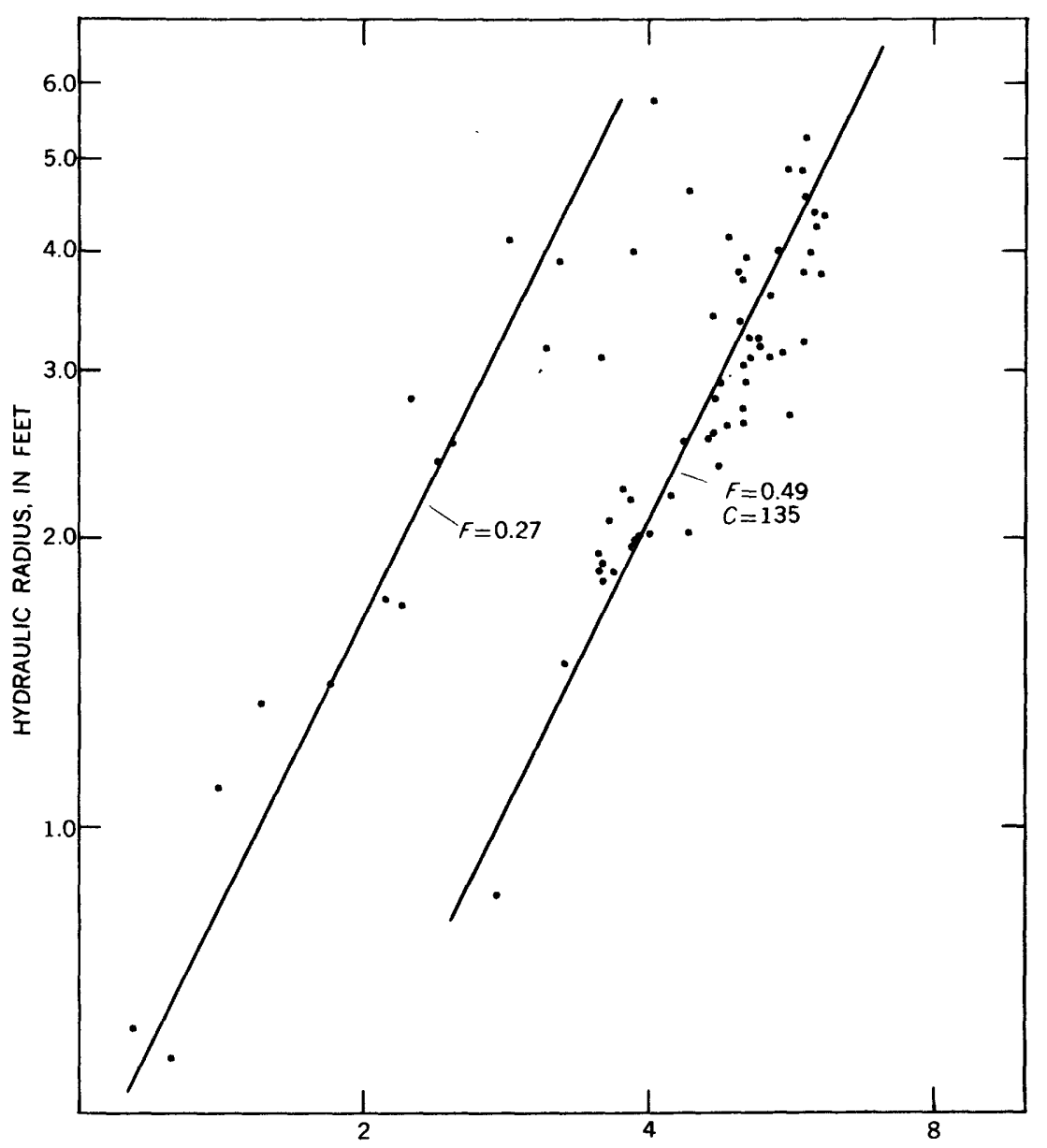

VELOCITY, IN FEET PER SECOND

Figore 7.-Relation of velocity to hydraulic radius for San Francisco riverside drain near Bernardo. 


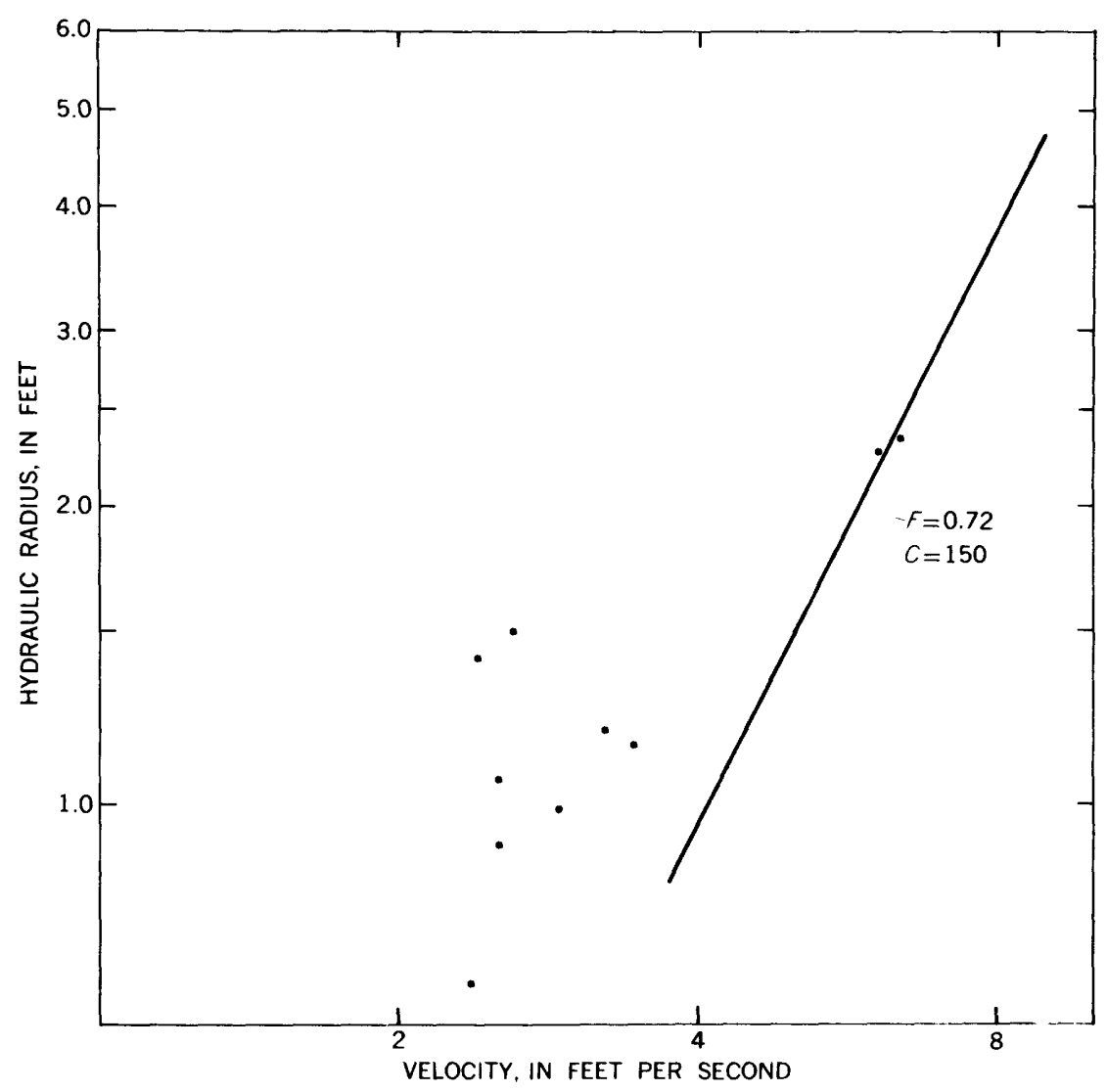

Figure 8.-Relation of velocity to hydraulic radius for Rio Grande at Socorro reach.

layer which must be broken before the stream once again becomes a sand-channel stream. The very rapid rises at this station also delay the change from lower to upper regime because the depth and velocity increase relatively more rapidly than accompanying changes in bed configuration. Measurements made during a rising stage were not used in defining the roughness factor for Rio Puerco because of the dubious accuracy of such measurements. All measurements over $750 \mathrm{cfs}$ other than those made on a rising stage were used.

\section{CRITERIA FOR ESTIMATING REGIME OF FLOW}

The determination of a criterion for estimating the regime of flow that will prevail in a sand-bed strean is necessary for many problems. In canal design the maximum capacity of discharge and sediment transport are functions of the regime of flow at the design depth. 
In channel rectification, the regime of flow determines the capacitance of the reach. In stream gaging, it determines the velocity of flow, as was shown in an earlier section. In problems concerning sediment transport, regime has an important bearing on the amount of sediment transported.

There have been several attempts at establishing a criterion for determination of regime of flow. Garde (1959) proposed an empirical relation involving a shear-Froude number relation. Field data do not verify the relation. In particular, part of the Rio Grande data for upper-regime flows would be estimated as lower regime (fig. 14). Disregarding the parameters used, the shape of the relation is believed to be in error. Because the Froude number virtually remains constant for upper-regime flows, any relation employing Froude number should not present the paradoxical situation, as Garde's does, that with a constant Froude number increasing depth can cause a transition from upper-regime to lower-regime flows. In addition, it is not believed that the Froude number is an adequate parameter for such a relation, because for a given Froude number flow may be in any regime depending upon the size of the bed material.

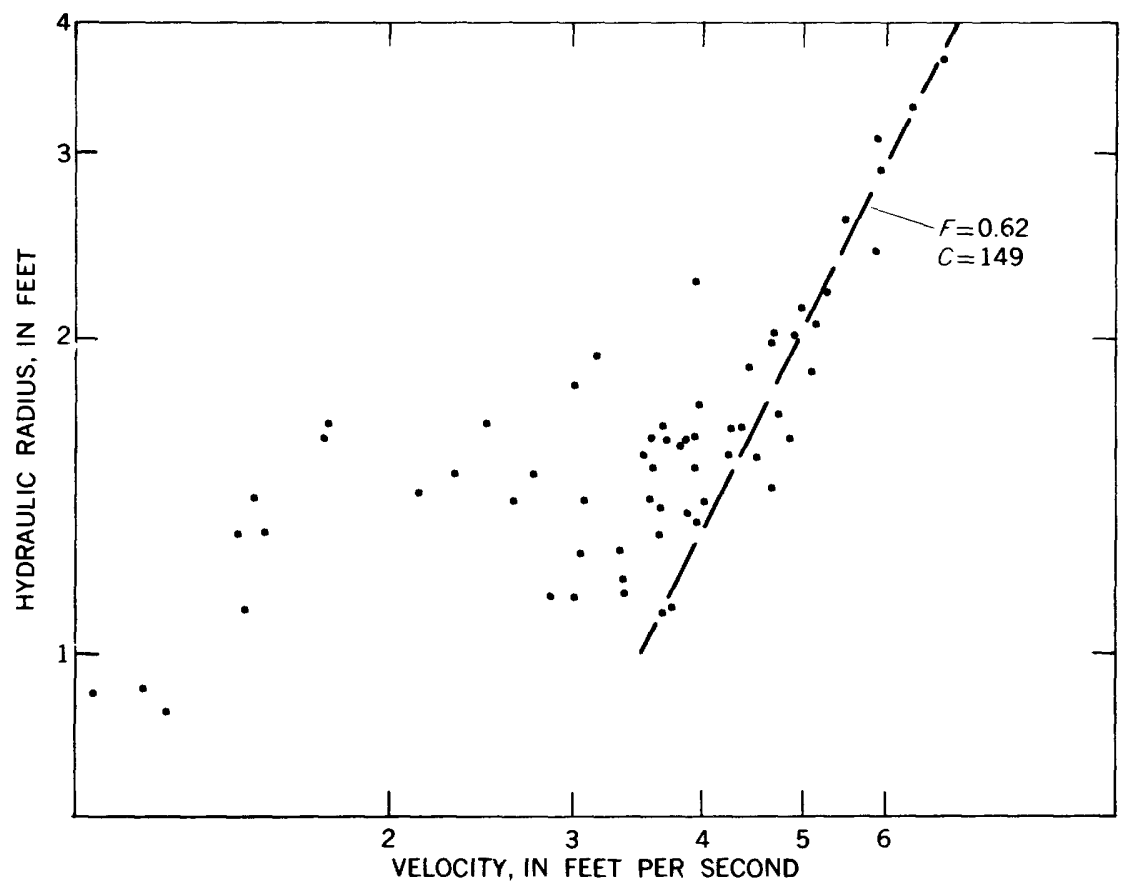

FiguRe 9.-Relation of velocity to hydraulic radius for the Rio Grande at San Antonio, January 1952-June 1953; October 1954-June 1955.

$690-2310-63-4$ 
Simons and others (1961) proposed a plot of $V_{*} d / \omega$ and $V_{*} / \nu$, with an empirical family of curves based on flume data which would delineate the various regimes. The Rio Grande data do not verify this plot (fig. 15). Because for a given stream, with a fixed slope and bed material, all data will plot on a $45^{\circ}$ line depending upon $R$, this family of curves is not believed to be adequate. For any situation without a unique relation of $R$ to $V$, regimes of flow would overlap on the Simons' plot, and it has been shown that there is no unique relation between $R$ and $V$ for true sand-bed streams. As an example, by referring to figure 5, it becomes obvious that at an $R$ of 2.1 at the Rio Grande near Bernalillo, lower, transition, and upper regimes of flow can occur at $V_{*}=\sqrt{2.1 g S \text {. }}$

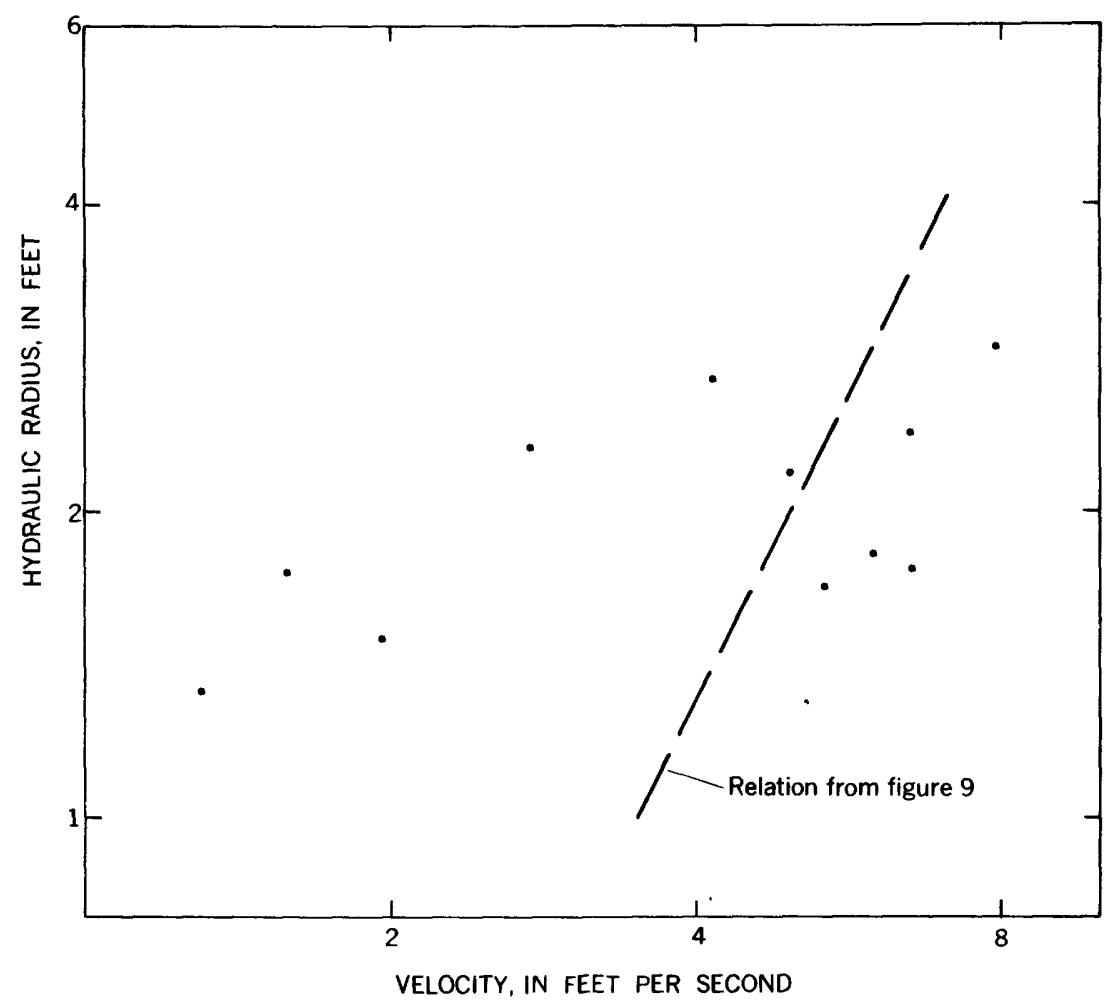

FIGURE 10,-Relation of velocity to hydraulic radius for the Rio Grande at San Antonio, July 1953-May 1954. 


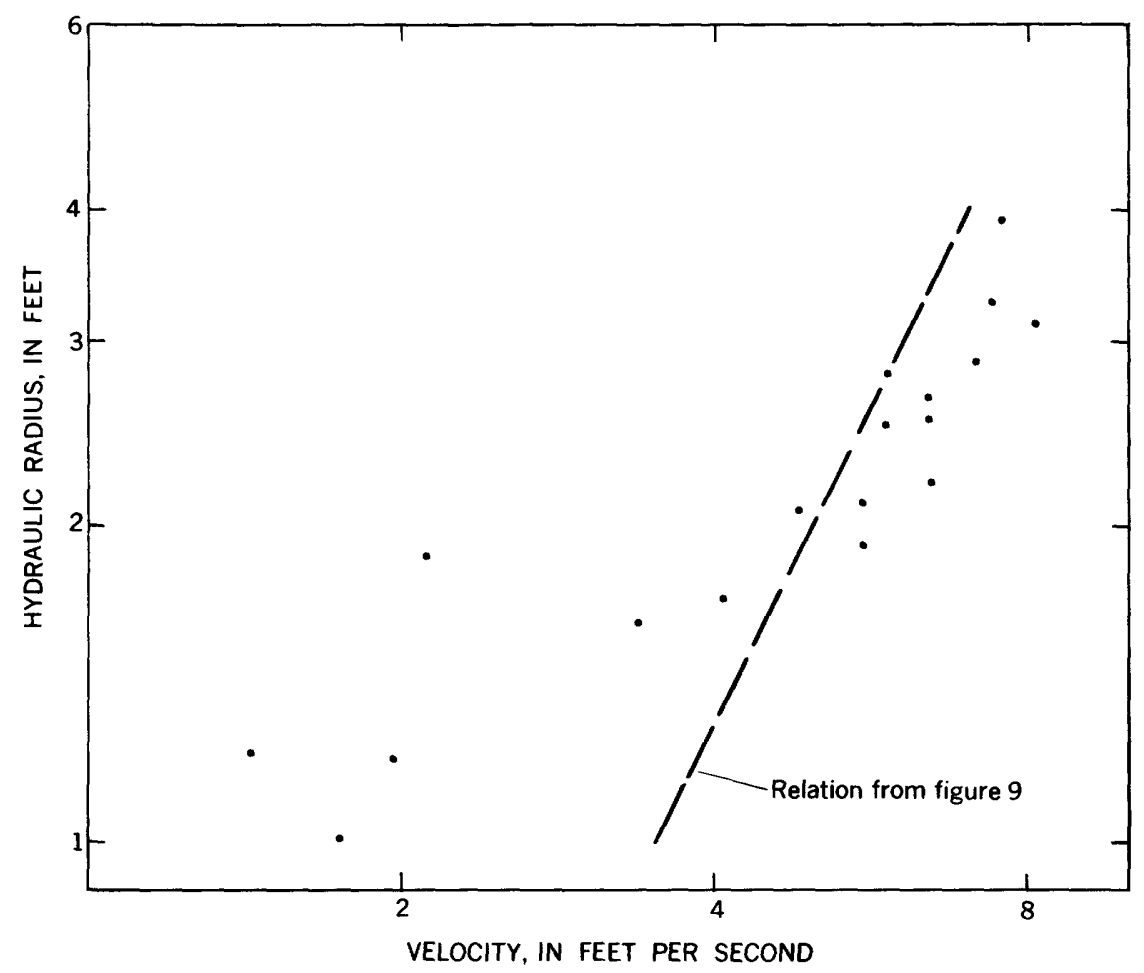

Figure 11.-Relation of velocity to hydraulic radius for the Rio Grande at San Antonio, May-September 1954; July-September 1955.

\section{RELATION OF CHEZY $C$ TO BED MATERIAL}

Figure 16 shows the variation of average Chezy $C$ for upper-regime flows with the median diameter of the bed material for stations covered in this report. Average values for all available upper-regime observations are plotted for the sand-bed stations. Individual observations are plotted for the sand-gravel stations, Otowi, Cochiti, and San Felipe. Also included are average values for several stations distributed throughout the country. These data are abstracted from Dawdy (1960) and show that the Rio Grande data are in agreement with data from other streams.

In general the reach above the Angostura diversion dam is a gravel alluvium over which a veneer of sand is transported. At higher discharges and correspondingly large sediment transport, the bed generally has areas bare of sand, with gravel exposed to the flow. At times an entire cross section may have a gravel bed. The variable 


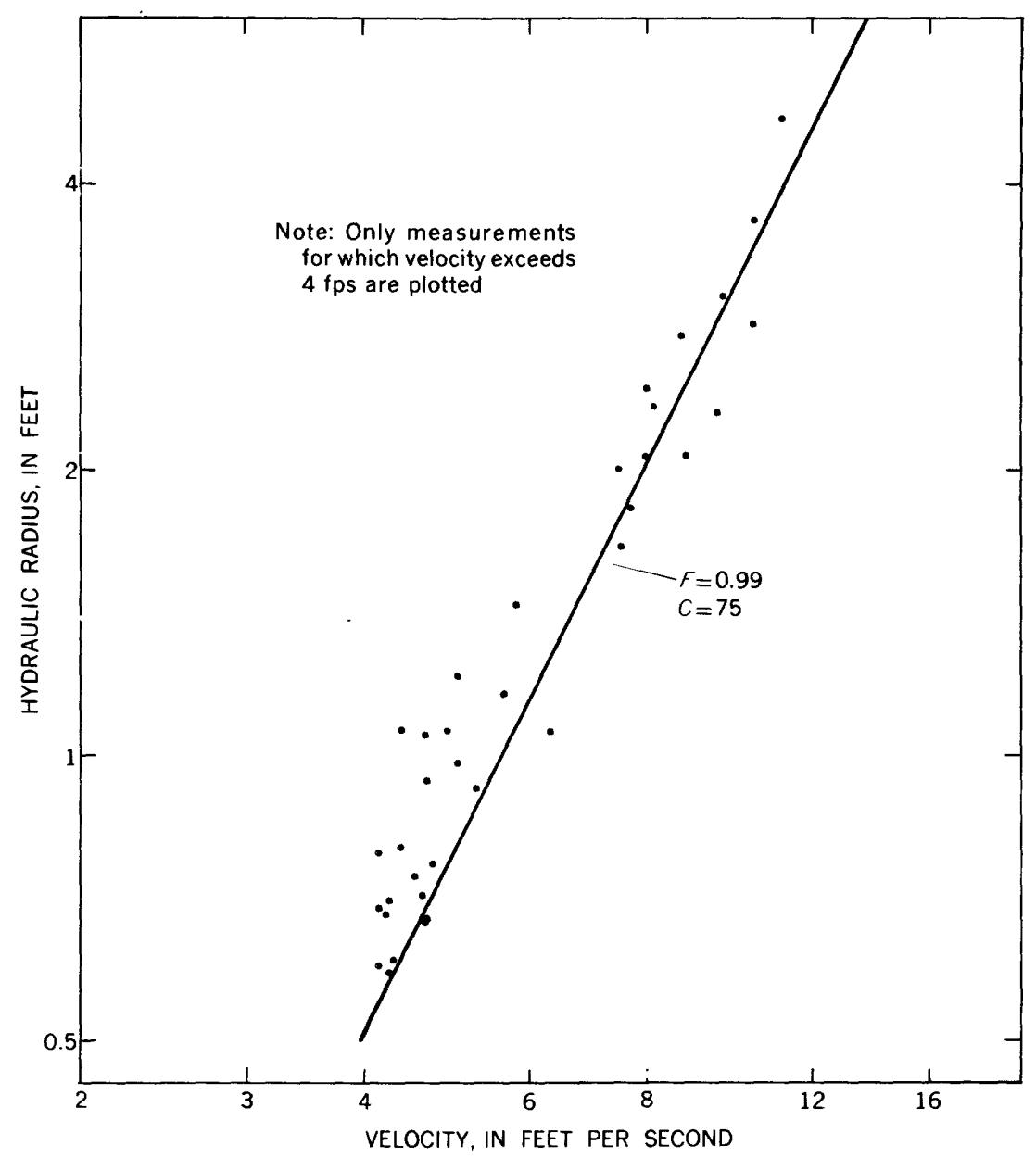

Figure 12,-Relation of velocity to hydraulic radius for Galisteo Creek at Domingo, N. Mex.

condition of the bed is indicated by samples of the highly variable bed material obtained at Otowi, Cochiti, and San Felipe. The variation in bed material causes a large amount of scatter in the relation of velocity to hydraulic radius and of shear to sediment transport.

Although of the three main-stem stations above Bernalillo, Cochiti most nearly approximates a sand-bed channel; it presents a good example of a sand-gravel channel, that is, one without a limitless supply of sand. As such, any relation developed for it may be used to interpret data for the reach from Otowi to San Felipe. The bedmaterial samples for Cochiti showed a large amount of variation in median diameter as compared with those of the sand-bed channel 
stations. In addition, although the station seems to experience upperregime conditions, the shifts in the velocity-hydraulic radius plot are extensive, as shown in figure 17 , and often seemingly are without reason. It was hypothesized that part of this shifting may be due to the changing bed material, with resultant changes in roughness.

A composite of the bed-material samples for each measurement made at Cochiti during May and June of 1957 and 1958 was taken to obtain an average median diameter for each measurement. (See table 3.) For this compositing, one sample of $0.13 \mathrm{~mm}$ median diameter was considered to have been taken near the bank in too slow a velocity, so that normally suspended fine-grained sediment was included in the sample. All samples of more than $1 \mathrm{~mm}$ were disregarded, because they were not considered to influence the roughness to a major extent. All except one measurement of more than $1 \mathrm{~mm}$ was taken in what appeared to be a local deposit of gravel near the left bank.

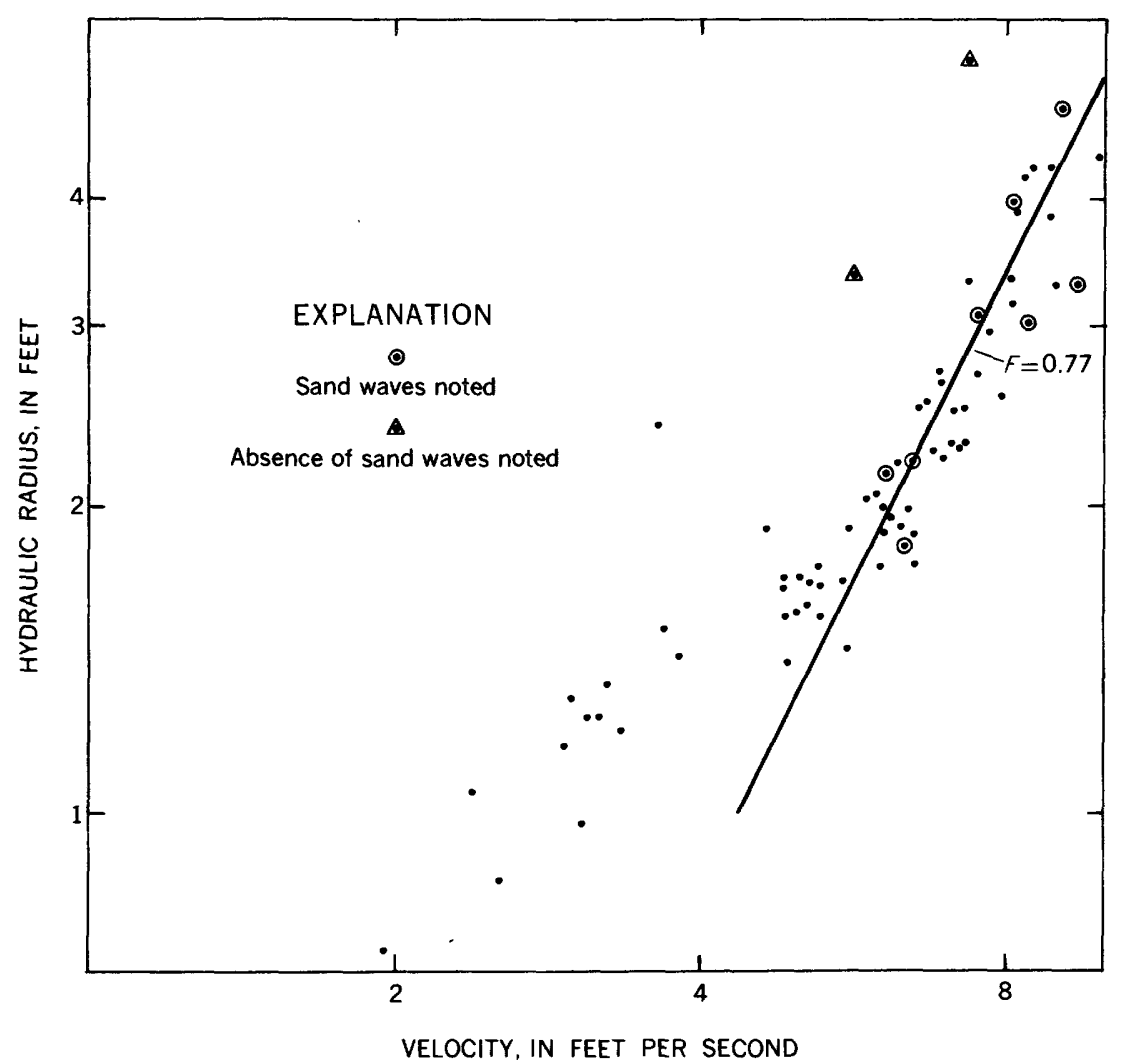

Figure 13.-Relation of velocity to hydraulic radius for Rio Puerco near Bernardo, N. Mex. 


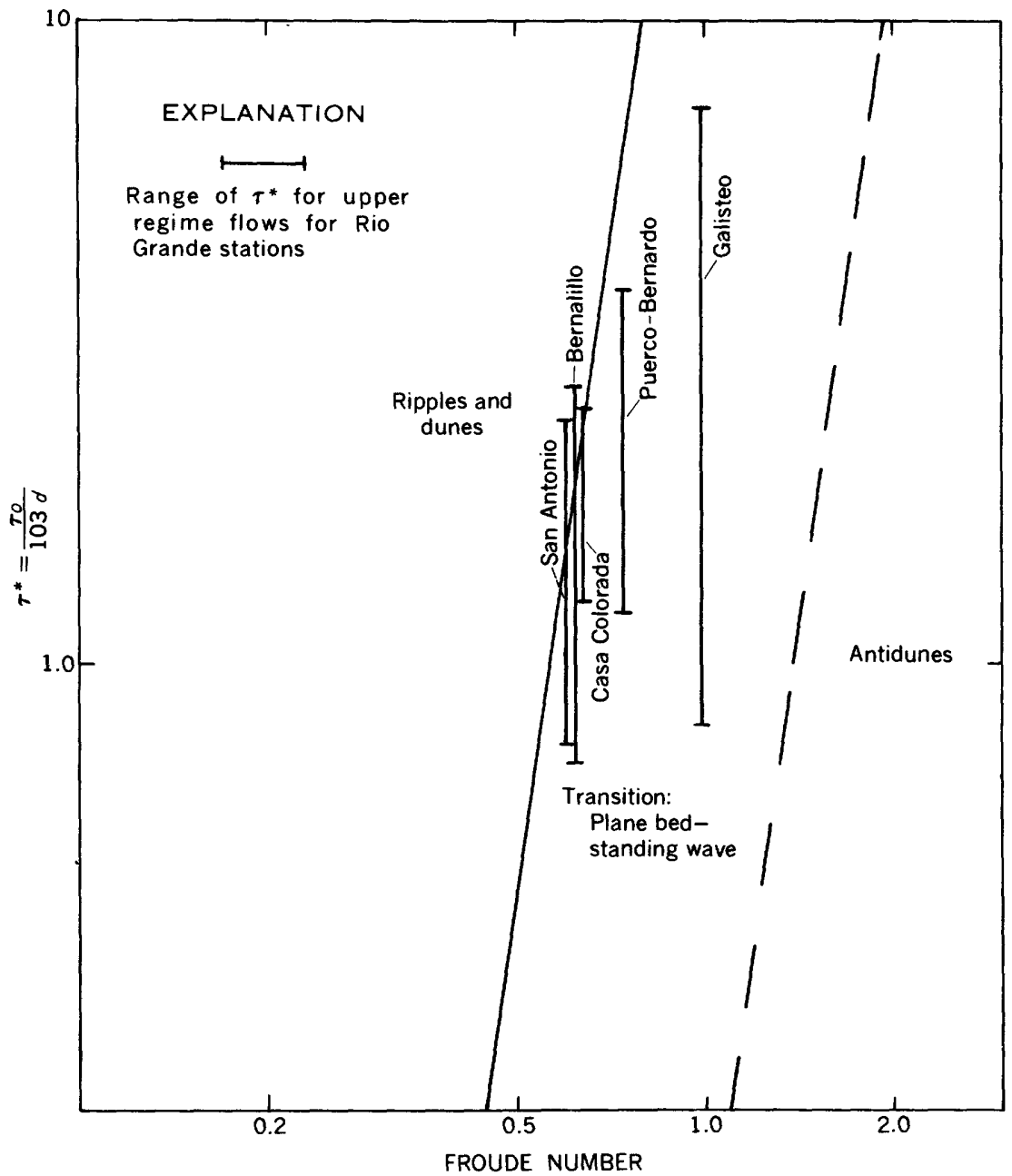

Figure 14.-Garde's criteria for regimes of flow in alluvial channels.

Chezy $C$ was computed for each measurement separately, using a constant slope of 0.0012 . The results are listed in table 4, along with the average median diameter. The variation in Chezy $C$ agreed generally with the variation in median diameter, and the trend for Cochiti agrees with that for the mean values at other stations in the basin. 
FLUVIAL CHARACTERISTICS AND HYDRAULIC VARIABLES F25

TABLE 3.-Median diameter of bed material, in millimeters, for the Rio Grande at Cochiti

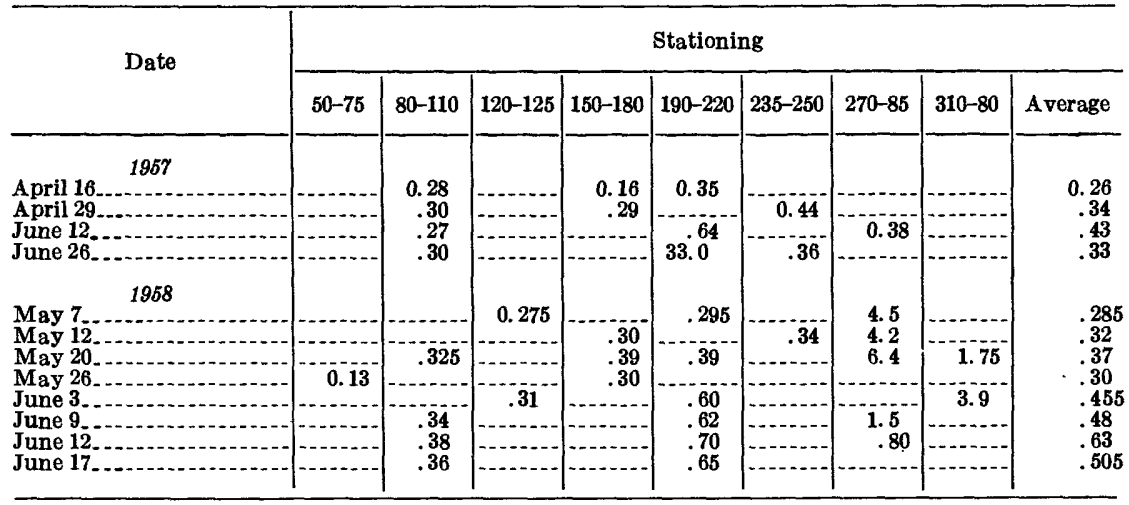

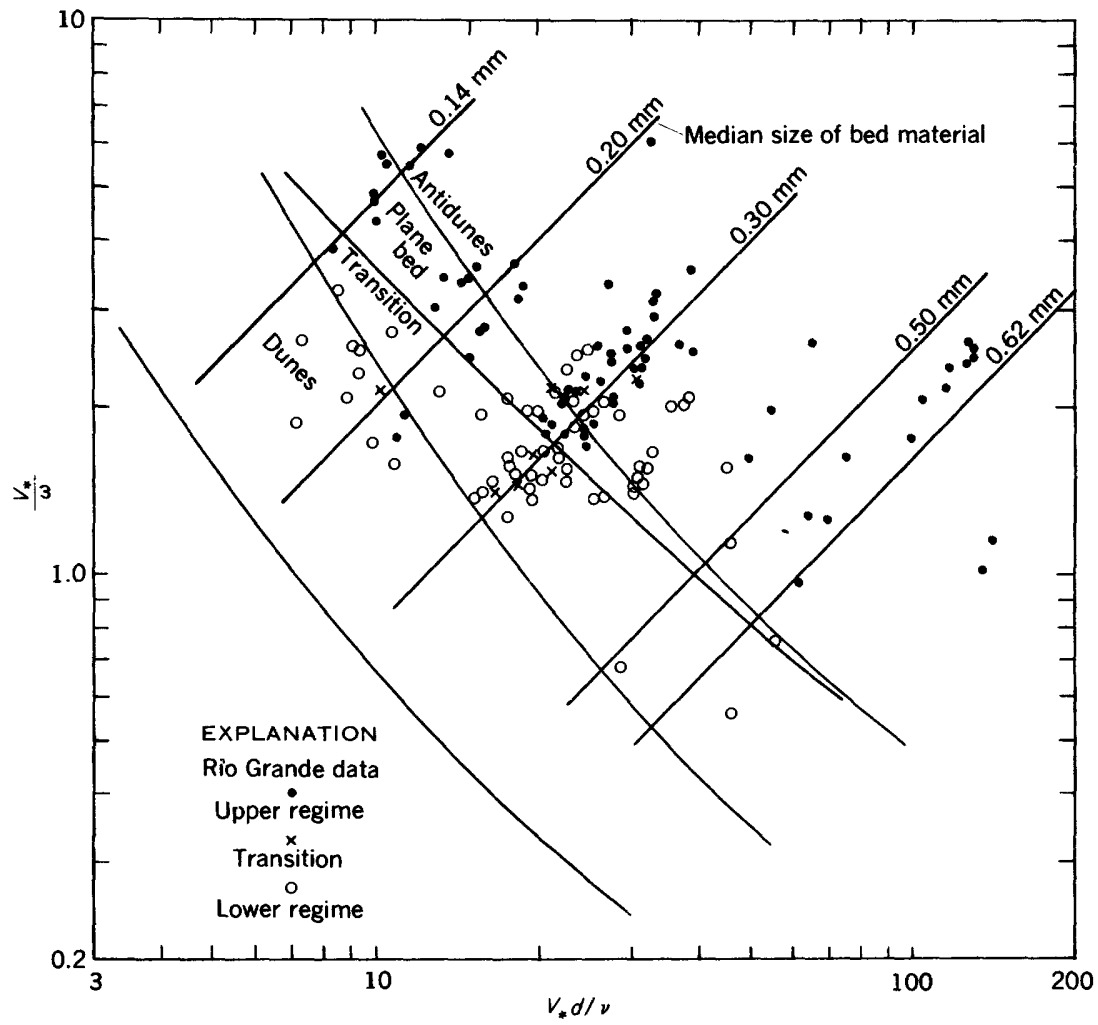

Figure 15.-Simons' criteria for regimes of flow in alluvial channels. 


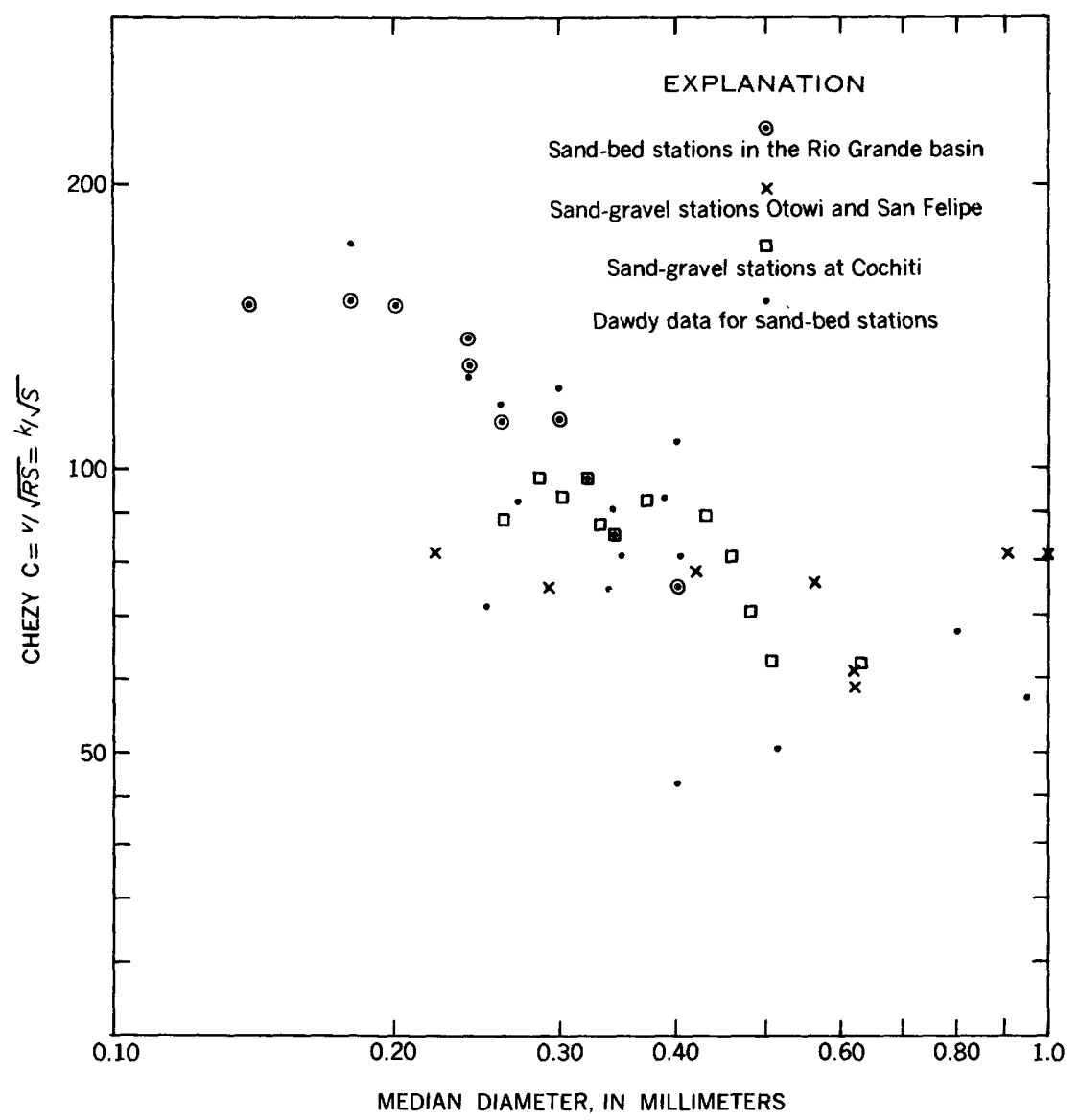

Figure 16.-Variation of Chezy $C$ with median diameter of bed material for upper regime flows.

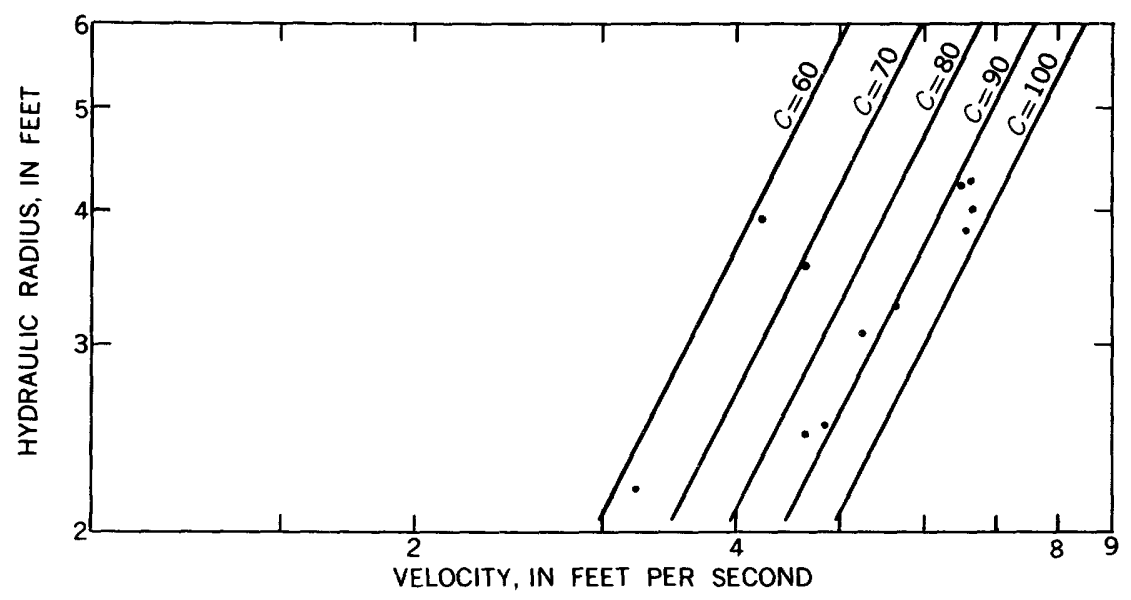

Figure 17.-Relation of velocity to hydraulic radius for Rio Grande at Cochiti. 
TABLE 4.-Median diameter and Chezy $\mathrm{C}$ for the Rio Grande at Cochiti

\begin{tabular}{|c|c|c|c|}
\hline Date & $\begin{array}{l}\text { Median diam- } \\
\text { eter (mm) }\end{array}$ & $k$ & $\begin{array}{c}\text { Chezy } C \\
=k S^{-3 / 5}\end{array}$ \\
\hline $\begin{array}{l}\text { May } 16 \\
\text { May } 29 \\
\text { June } 12\end{array}$ June 26. & $\begin{array}{l}0.26 \\
.34 \\
.43 \\
.33\end{array}$ & $\begin{array}{l}3.05 \\
2.95 \\
3.12 \\
3.02\end{array}$ & $\begin{array}{l}88 \\
85 \\
90 \\
87\end{array}$ \\
\hline 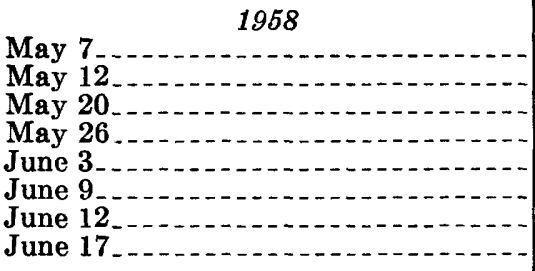 & $\begin{array}{l}.285 \\
.32 \\
.37 \\
.30 \\
.455 \\
48 \\
.63 \\
.505\end{array}$ & $\begin{array}{l}\text { 3. } 38 \\
\text { 3. } 35 \\
\text { 3. } 18 \\
\text { 3. } 22 \\
\text { 2. } 80 \\
\text { 2. } 45 \\
\text { 2. } 15 \\
\text { 2. } 15\end{array}$ & $\begin{array}{l}98 \\
97 \\
92 \\
93 \\
81 \\
71 \\
62 \\
62\end{array}$ \\
\hline
\end{tabular}

\section{OTHER FACTORS INFLUENCING ROUGHNESS}

Factors other than bed-material size that have been offered as influencing roughness in alluvial streams are relative roughness (Leopold and Wolman, 1957), channel-shape factor (Brooks, 1958), standard deviation of the bed material (Einstein and Chien, 1958), and concentration of suspended sediment (Leopold and Maddock, 1953, Brooks, 1958).

\section{RELATIVE ROUGHNESS}

In analyzing bed roughness, Einstein (1950) divided the total shear force into two parts, the shear force owing to form roughness, and the shear force owing to grain roughness. For upper-regime flows in sand-bed channels, form roughness due to bed configuration is negligible. Using Nikuradse's relative roughness parameter, $4 R / d$ (Rouse, 1949 , p. 209-212), to describe a grain roughness for our data, it is apparent that the effect of relative roughness on total roughness is small. The range in relative roughness for upper-regime flow data presented in this report is about 1,800 to 57,000 , with the greatest range at a station being 1,800 to 14,000 at Galisteo Creek. According: to the Nikuradse curves, a relative roughness of 1,800 gives a friction factor, $f$, of about 0.017 , and a relative roughness of 14,000 gives a friction factor of about 0.0115 . Over this range of relative roughness for the Galisteo Creek station, the grain roughness should vary only about one-third. All our upper-regime data have high Reynolds numbers, so that there is no Reynolds number effect on total roughness. These data indicate that, although variations in depth at a station do 
occur during upper-regime flows, the total roughness expressed as Chezy $C$ does not vary appreciably over this range of relative roughness.

\section{ChaNNEL SHAPE}

The channel shape as expressed in the width-depth ratio does not appear to affect the roughness, at least in channels of the width of those studied in this report. A good illustration of this is the two Bernalillo sections $A-2$ and $F$. Section $A-2$ is in a contracting reach. It is a comparatively narrow section of fixed width, ranging only from 265 to 275 feet in width for flows exceeding $1,000 \mathrm{cfs}$. Section $F$ is in an expanding reach, and the width ranges from 300 to 600 feet for the same flows.

The energy gradients through the two sections were shown earlier to be mainly the same (fig. 4). The relations of velocity to hydraulic radius for the two are quite similar, both for the upper and lower regimes. Both change from lower to upper regime at a depth of about 2 to 2.5 feet. The only major difference between the two is that section $A-2$ is narrower and, therefore, attains greater depths.

Figure 18 shows the relation of velocity to hydraulic radius for the two sections. The average trend drawn for the two plots is the same. Figure 5 shows a composite plot of the measurements at both stations, with the same trend line drawn. This indication that the width-depth relation is not a factor in the determination of roughness is borne out by the Casa Colorada reach, where data, for sections having different width-depth ratios but similar slopes plot together on one velocity relation (fig. 6).

\section{STANDARD DEVIATION OF BED MATERIAL}

The variability of the bed-material size as measured by the standard deviation and the suspended-sediment concentration have been shown by Dawdy (1960) not to affect roughness appreciably. The inaccuracy of the measure of standard deviation was given as the probable reason for lack of noticeable effect for that variable. Standard deviations determined for stations in the Rio Grande basin are more accurately defined than most of those used by Dawdy, but they are insufficient in number and too highly correlated with median diameter to define any effect of standard deviation on roughness. Values of standard deviation and median diameter for the Rio Grande stations are given in the following table: 


\begin{tabular}{l|r|r}
\hline Rio Grande station & $\begin{array}{c}\text { Median diameter } \\
\text { of bed material }\end{array}$ & $\begin{array}{r}\text { Standard devia- } \\
\text { tion of bed } \\
\text { material }\end{array}$ \\
\hline At Otowi. & 0.62 & 2.61 \\
At Cochiti & .44 & 2.11 \\
At San Felipe & .67 & 2.04 \\
Near Bernalillo. & .30 & 1.68 \\
Near Belen & .24 & 1.55 \\
Near Bernardo (SFRD) & .26 & 1.42 \\
Near Socorro & .18 & 1.52 \\
At San Antonio. & .20 & 1.48 \\
At San Marcial & .14 & 1.43 \\
\hline
\end{tabular}

\section{SUSPENDED-SEDIMENT CONCENTRATION}

As to suspend-sediment concentration, there is a large variation at each individual station, and a variation between stations that bears out the point made by Dawdy that suspended loads do not have an effect on roughness for the upper-regime flows. This is verified by laboratory studies conducted by the U.S. Geological Survey at Colorado State University (Haushild, 1960).

\section{SUMMARY OF OTHER FACTORS INFLUENCING ROUGHNESS}

In conclusion, it appears that for the sand-bed streams of the middle Rio Grande, roughness for a given reach, as expressed by Chezy $C$, is approximately constant for upper-regime flows. Also, roughness for lower-regime flows appears to be approximately constant for a given reach, however, insufficient data are available at this time for definite conclusions. Chezy $C$, for upper-regime flows at a station, mainly is a function of the size of the bed material. The variability of the bed material, as measured by the standard deviation, also may be a factor, but there is no positive evidence at this time. The effect of the depth-roughness ratio, width-depth ratio, and suspended-sediment concentration do not appear to be significant variables in determining roughness for upper-regime flows in sand-bed streams. Further research is needed, both in the field and laboratory, to define lower and transition regime relations for sandbed streams.

\section{CHANGES IN BED ELEVATION}

It is a commonly held belief that beds of sand-channel streams scour during periods of high flow. This belief is based on evidence of two types. First, stage-discharge ratings for sand-channel streams often are discontinuous. Thus, for a given water stage, two widely different discharges can be accommodated. Many field personnel explain 
F30 STUdiEs OF FLOW IN ALLUVIAL CHANNELS

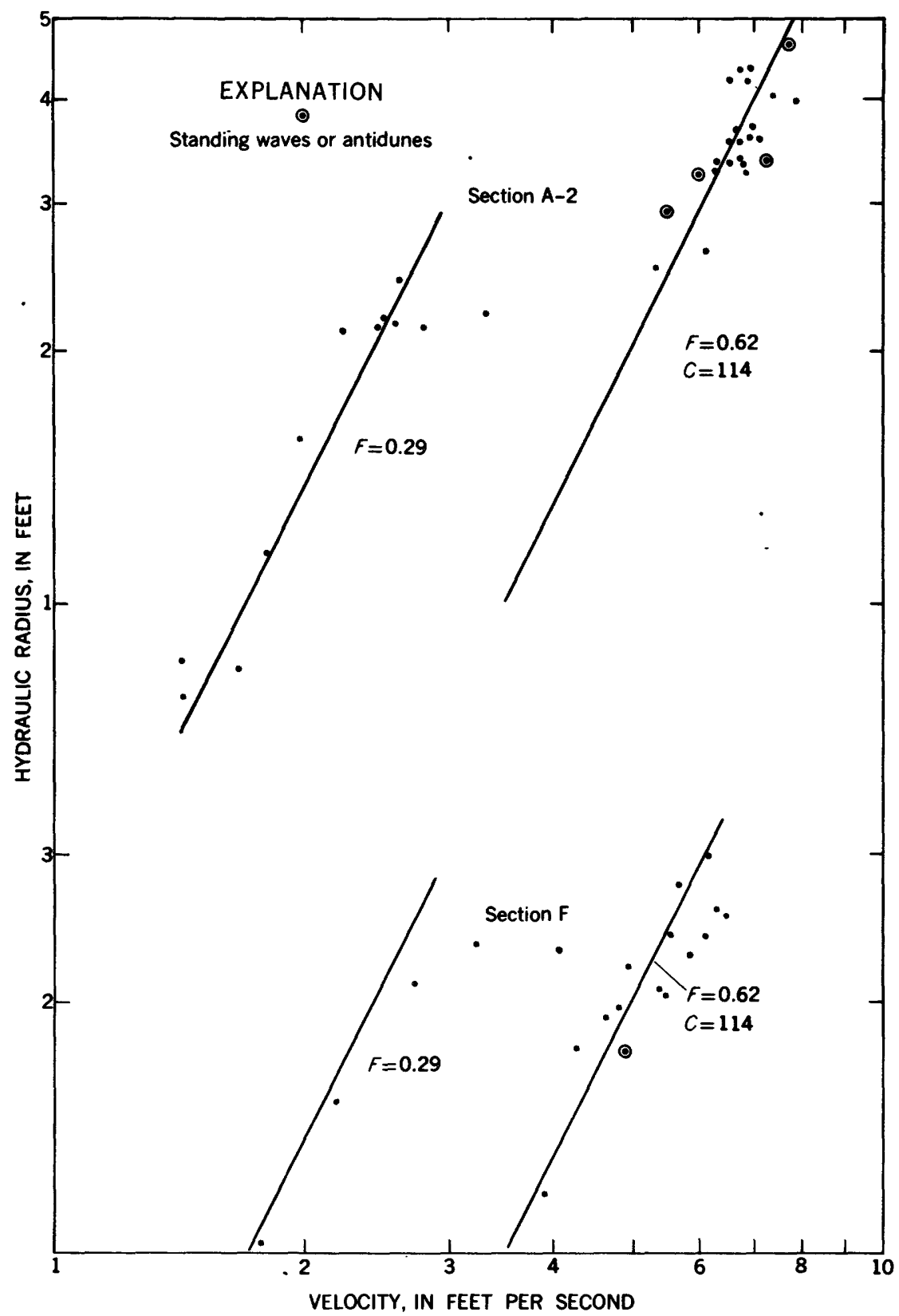

Figure 18, -Relation of velocity to hydraulic radius for Bernallilo sections $\boldsymbol{A - 2}$ and $\boldsymbol{F}$. 
the higher discharge of the two as being due to scour of the bed, whereas it is actually due to a change in bed roughness that increases the velocity of flow for a given depth of water. Second, gaging stations often are situated at constrictions in the channel. At these points, it is possible that great local scour and fill does occur. However, they may not be typical of a representative reach of the channel.

There is a strong possibility that over a reach of several miles there may be sections that scour at high flows and fill at low flows, which are counterbalanced by sections that fill at high flows and scour at low flows (Lane and Borland, 1954). Thus, over a time period the reach would approach the condition of a graded stream.

Sediment-discharge records would seem to be an obvious method of determining net aggradation or degradation of long reaches of channel. However, there are few reaches, if any, in the country where sediment discharge is determined accurately enough to estimate the degree of deposition of sediment in the channel. Generally, suspended sediment only is measured that omits an unmeasured part near the stream bed.

In the middle Rio Grande basin, described in this study, many unmeasured tributaries and major diversions greatly complicate any attempt at estimating total sediment movement, other than at a section, with no accurate relation to other measuring sections possible. Any estimate of total sediment movement must be obtained by an indirect method. Using the reach from Otowi to Bernalillo as an example, it can be shown that the $1 \frac{1}{2}$ feet of scour or drop in bed elevation, which occurred at section $\mathrm{A}-2$ at Bernalillo during the period from April 15 to June 20, 1952, cannot be a general condition through the reach. The distance from Otowi to Bernalillo is about 56 miles. Assume an average channel width of 250 feet during the 2-month period, and assume the deposited sediments have a specific weight of $64 \mathrm{lb}$. per cu. ft. The amount of sediment necessary to be moved in order for this reach to scour this amount is:

$$
\frac{56 \times 5,280 \times 250 \times 1.5 \times 64}{2,000}=3,600,000 \text { tons. }
$$

The measured suspended-sediment discharge passing the Bernalillo section $A-2$ station during this period was only about $2,900,000$ tons plus an estimated 250,000 tons through Albuquerque main canal. Inflow of sediment at Otowi was 2,100,000 tons and from the Jemez River about 170,000 tons. 
Using these figures of suspended discharge as an index to totalsediment discharge, less than one-fourth of the $1 \frac{11}{2}$ feet of scour possibly could be a general condition throughout this 56 mile reach. Considering that the result is arrived at by subtracting two very large numbers, each of which is subject to considerable error, no exact estimate of scour can be made, but section $A-2$ at Bernalillo is definitely not a typical cross section of this reach in regard to degree of scour and fill. Lane and Borland (1954) used reasoning of this sort in arriving at a similar conclusion as to the nonrepresentativeness of the normal river gaging station.

Periodic measurements of bed elevation over a period of time would be an even more direct method of determining changes in bed elevation. To study changes over a reach, however, readings must be obtained at several sections to draw any general conclusions. The only data available for which several cross sections in a reach were measured over a period of time are the observations in 1952 near Bernalillo and in 1957 and 1958 at Casa Colorada.

Near Bernalillo, 13 cross sections were measured 6 times during the spring runoff of 1952 . The patterns of scour and fill were not similar at the different cross sections. (See fig. 19.) Although all sections had a net scour between the first and the last observation, at least 3 sections filled and at least 4 scoured between each sequent pair of measurements. The average range in bed elevation was about a foot, with a maximum of about 1.5 feet at the lower end of the reach and a minimum of about 0.3 foot at sections $A-1$ and $D$. Section $A-2$ had a range of about 1.25 feet and section $F$, a range of about 1 foot.

At the Casa Colorada reach, near Belen, 5 measurements were made in 1957 and 4 in 1958 at 6 different sections. The 1957 flow was the first high water to pass the reach after channel rectification. Two of the sections, 117.43 and 116.47, were unstable the first year (fig. 20). In general, however, the entire reach filled between 1957 and 1958 . The major exception was section 117.05 , the narrowest section in the reach, which scoured more than a foot between August 1957 and April 1958 , creating a negative bed slope from 117.05 to the next downstream section 116.67 .

The 1958 observations at Casa Colorada gave results similar to those at Bernalillo in 1952. The slopes in the upstream and downstream parts of the reach were approximately equal (table 2 ). In each place one of the middle sections was narrow in relation to the other sections, section $E$ at Bernalillo and section 117.05 at Casa Colorada. The slope in the vicinity of these narrow sections was substantially flatter than in the rest of the reach. The scour and fill pattern, as discussed earlier, well may be an adjustment of area in order to maintain the fixed-energy slope. 
FLUVIAL CHARACTERISTICS AND HYDRAULIC VARIABLES F33

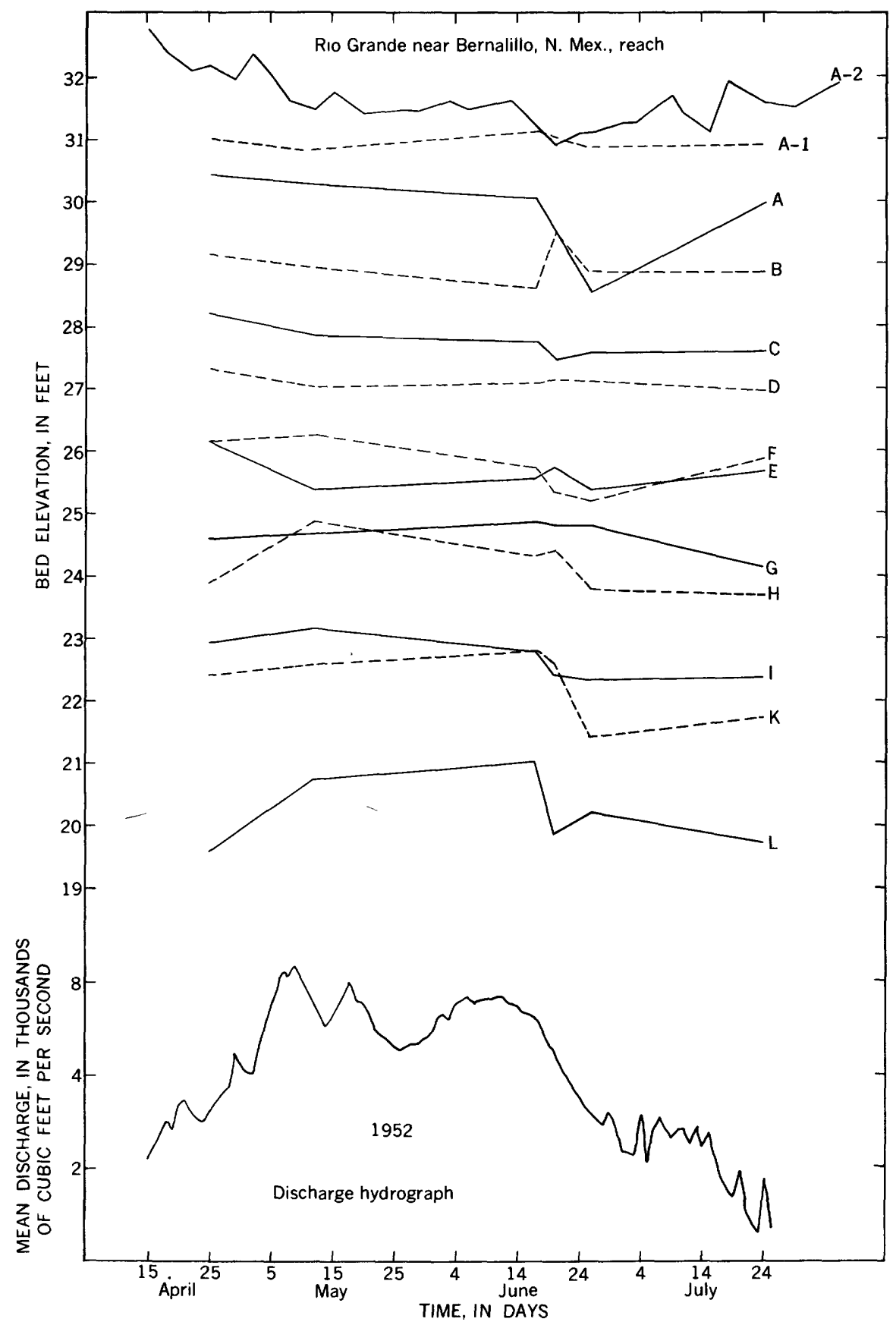

FIGURE 19.-Changes in bed elevation during 1952 spring runoff at Bernalillo reach. 


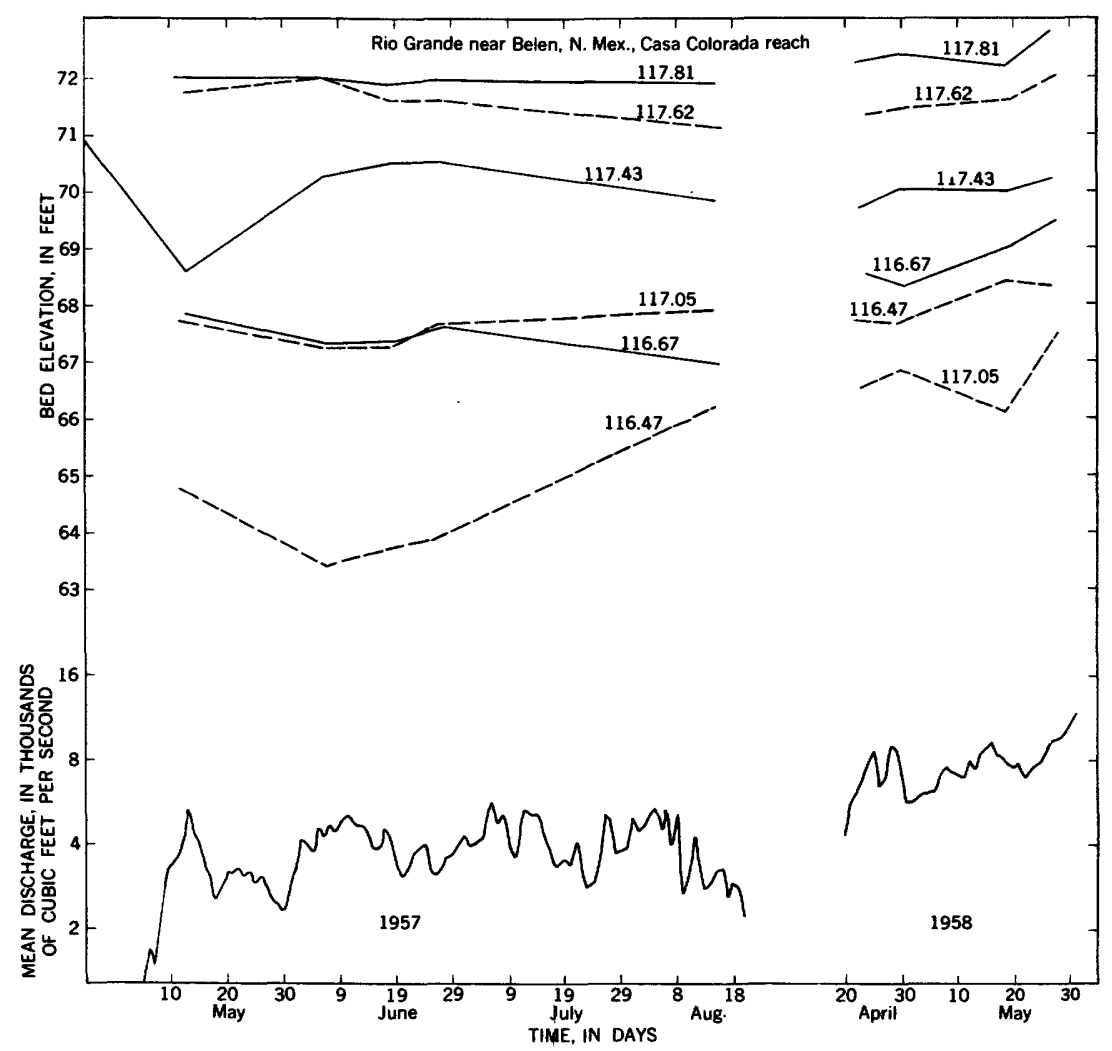

FIGURE 20.-Changes in bed elevation during 1957 and 1958 spring runoff at Casa Colorada reach.

This same conclusion follows from a consideration of the mechanics of the system. It was shown earlier that for a given regime of flow, roughness is constant throughout the Bernalillo and Casa Colorada reaches. Also, it was indicated that energy slope is principally constant over the same reaches. Therefore, for a given regime prevailing throughout a reach, both Chezy $C$ and energy slope may be assumed constant. From figure 21, the friction head loss, $h_{f}$ is:

$$
\begin{aligned}
h_{f} & =\left(Z_{1}-Z_{2}\right)+\left(R_{1}-R_{2}\right)+\left(V_{1}^{2} / 2 g-V_{2}^{2} / 2 g\right) \\
& =\left(Z_{1}-Z_{2}\right)+R_{1}\left(1-R_{2} / R_{1}\right)+V_{1}^{2} / 2 g\left(1-V_{2}^{2} / V_{1}^{2}\right)
\end{aligned}
$$

Since $-\mathrm{Q}=A V \approx b R V$ and $V=C R^{1 / 2} S^{1 / 2}$,

Then- $h_{f}=\left(Z_{1}-Z_{2}\right)+R_{1}\left(1+C^{2} S / 2 g\right)\left(1-\left(b_{1} / b_{2}\right)^{2 / 3}\right)$. 


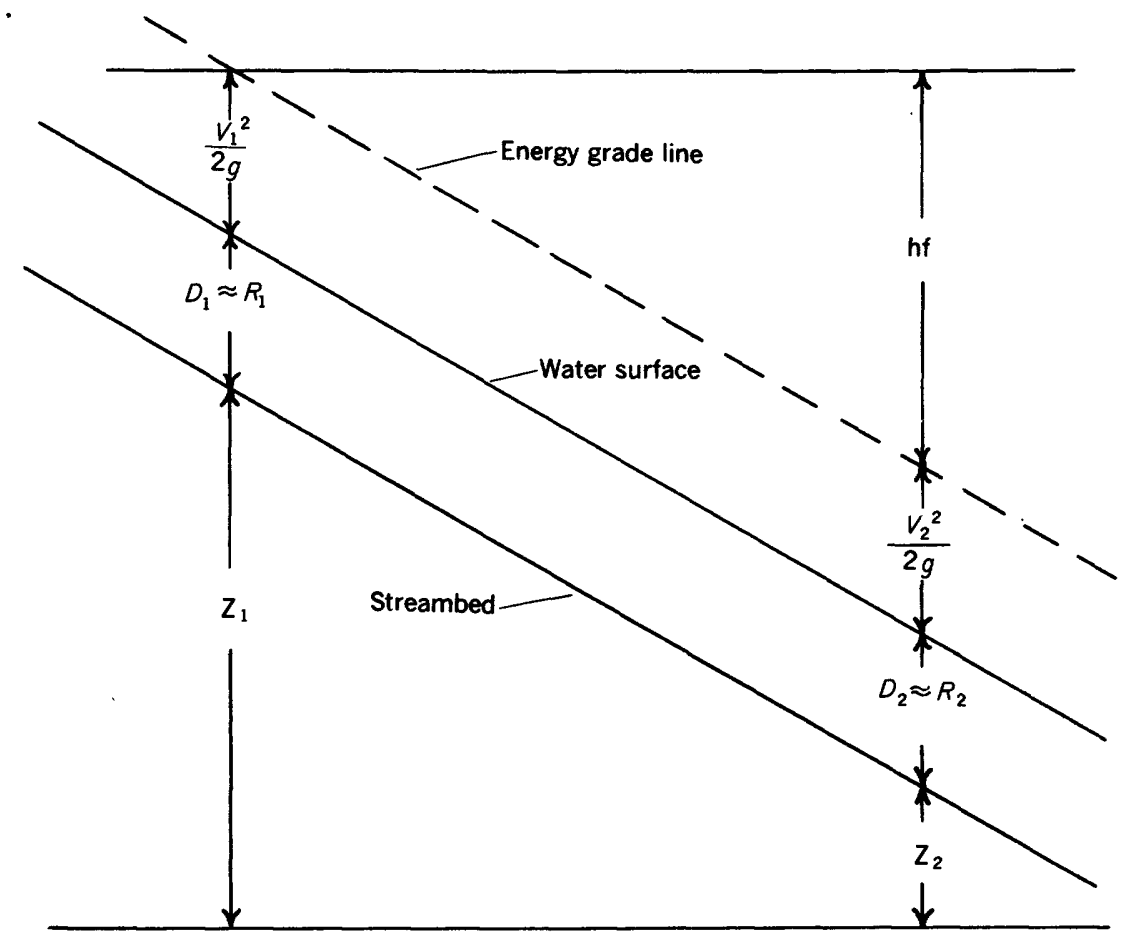

Figure 21.-Schematic diagram showing friction head loss in open-channel flow.

For a contracting reach $b_{1}>b_{2}$, and the second term on the right side of the equation is negative. If the ratio of $b_{1}$ to $b_{2}$ is constant, then as discharge increases, $R$ increases. Therefore, for $h_{f}$ and thus energy slope to remain constant, $Z_{1}-Z_{2}$ must increase either through fill at the upper section or scour at the lower section, or both. In the usual field case for a contracting reach, the ratio of $b_{1}$ to $b_{2}$ increases with discharge, so that the reasoning is even more compelling. Similar reasoning applied to the case of an expanding reach shows the same pattern of scour and fill at alternate sections. Also, it follows that those stations which fill on the rise should scour on the recession and vice versa. Thus, if energy gradient is to remain constant, any changes in width along a reach will be compensated for by scour and fill, so that the change in the ratio of the widths at any two sections is related inversely to the change in the ratio of the hydraulic radii. The changes in area through such a reach are very conservative. The discharge is altering the depth constantly through alternate scour and fill in order to maintain an approximately constant energy gradient and cross-sectional area. 
Therefore, it seems that the scour and fill that occurs during high water often may be local in extent. In narrow or contracting sections, the bottom scours during periods of increasing flow and fills during periods of diminishing flow. In wide or expanding sections the opposite seems to be true. For instance, sections $A-2$ to $E$ at Bernalillo are relatively narrow, whereas sections $F$ to $L$ are wider sections. (See fig. 2.) A comparison of the mean bed elevations (fig. 18) for the two measurements made on April 25 and May 12 during the rising stage show all sections from A-2 to $E$ scoured, whereas all sections from $F$ to $L$ filled. Similarly, during the falling stage the 2 measurements made June 26 and July 24 show a general tendency toward filling for the narrow section ( 3 filled, 1 scoured, 3 had no change), and a general tendency toward scouring for the wider sections (2 filled, 3 scoured, 1 had no change). Because most gaging stations are maintained at narrow, contracting sections, much of the evidence concerning scour and fill patterns based on gaging station records is biased toward a belief in scouring on the rise and filling on the recession.

\section{SEDIMENT TRANSPORT FUNCTIONS}

The measure of the total quantity of sediment transported by streams is desired for many problems concerning reservoir design and channel stability. Methods have been devised and standardized to measure that part of the sediment transported in suspension by water. That part of the sediment transported as bedload, however, cannot be measured at this time except indirectly.

Many theories have been proposed to determine total sediment. transport. Most theories, however, merely derive the form of the variables to be considered. Generally, sediment transport is related to boundary shear. Two theories attempt to predict the functional relation a priori. They are those proposed by Einstein (1950) and by Bagnold (1956). On the basis of field data, Colby and Hembree (1955) modified the Einstein theory for computing total sediment loads. The Bangold theory as yet has not been subjected to the test of applicability in the field.

The relation of sediment transport to shear and a study of both the modified Einstein method and the Bagnold theory for computing total sediment loads are presented in the following sections.

\section{RELATION OF SEDIMENT TRANSPORT TO SHEAR}

Mean velocity approximately doubles with a change from lower to upper regime, if mean depth or hydraulic radius remains constant. On the other hand the increase in suspended-sediment transport that accompanies this change in regime is approximately 8 to 10 times. Data for the Bernalillo and Casa Colorada reaches are plotted in figures 22-24 to illustrate this increase in transport with the change 
FLUVIAL CHARACTERISTICS AND HYDRAULIC VARIABLES F37

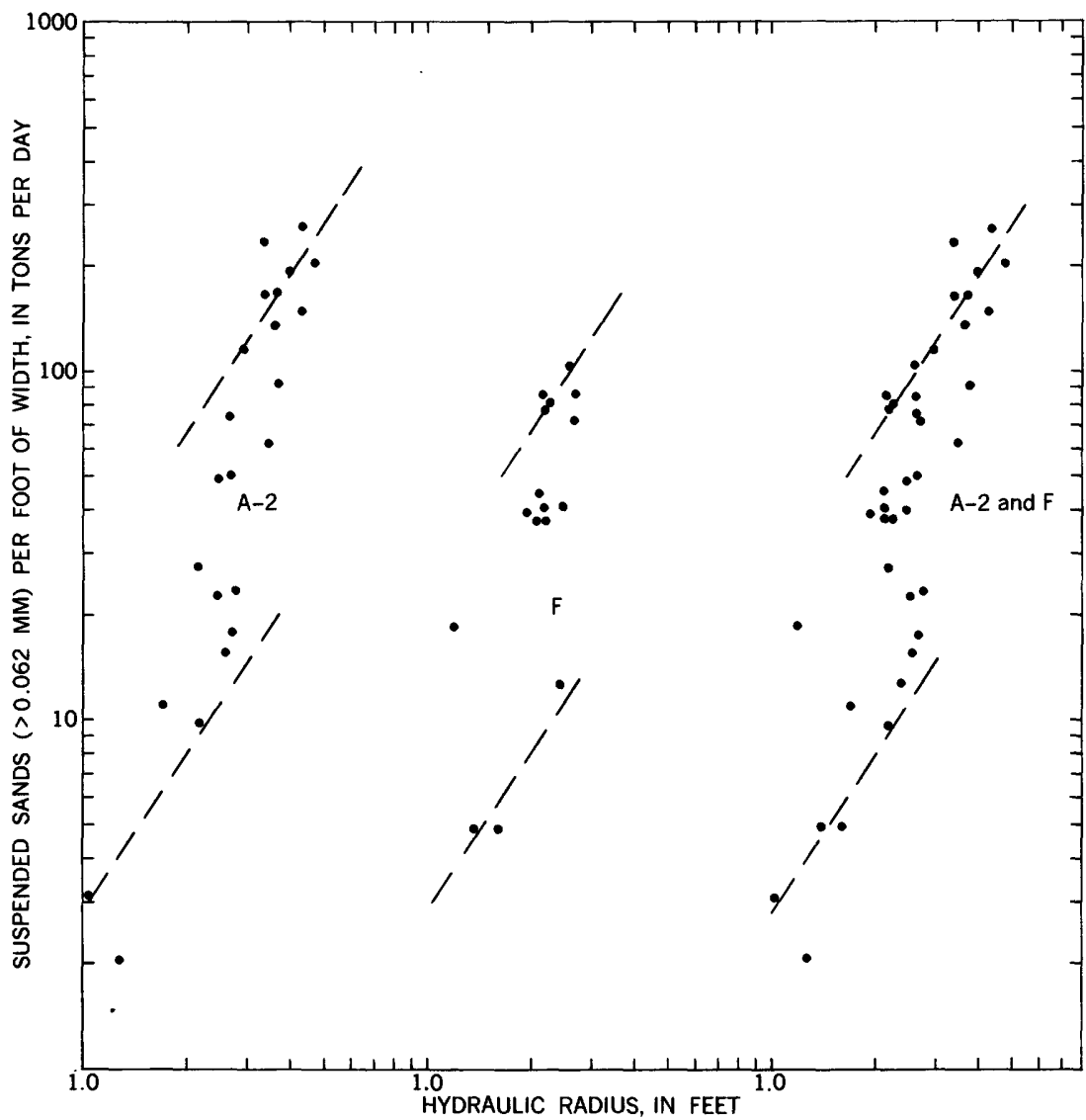

FIGURE 22.-Relation of suspended sands to hydraulic radius for Bernalillo sections $A-2$ and $F$.

from lower- to upper-regime flows. Suspended-sand load varies as the three-halves power of hydraulic radius. In a previous section, velocity was related to the square root of the hydraulic radius for ùpper-regime flows. This is equivalent to Colby's relation (1957) of sediment load varying as the cube of the velocity.

Figure 22 shows the two sections, $A-2$ and $F$, for the Bernalillo reach. Figure 23 is a combined plot of sections $A-2$ through $F$ for the reach. It is apparent that the same relation holds for any individual cross section in the reach regardless of width. By comparing figure 22 with the velocity-hydraulic-radius-relation curve in figure 5 , it can be seen that the break occurs for both velocity and sediment transport at depths slightly over 2.0 feet.

Figure 24 shows a plot of hydraulic radius and suspended sands for all sections in the Casa Colorada reach. The well-defined break from lower to upper regime occurs at a depth of about 1.80 feet. 


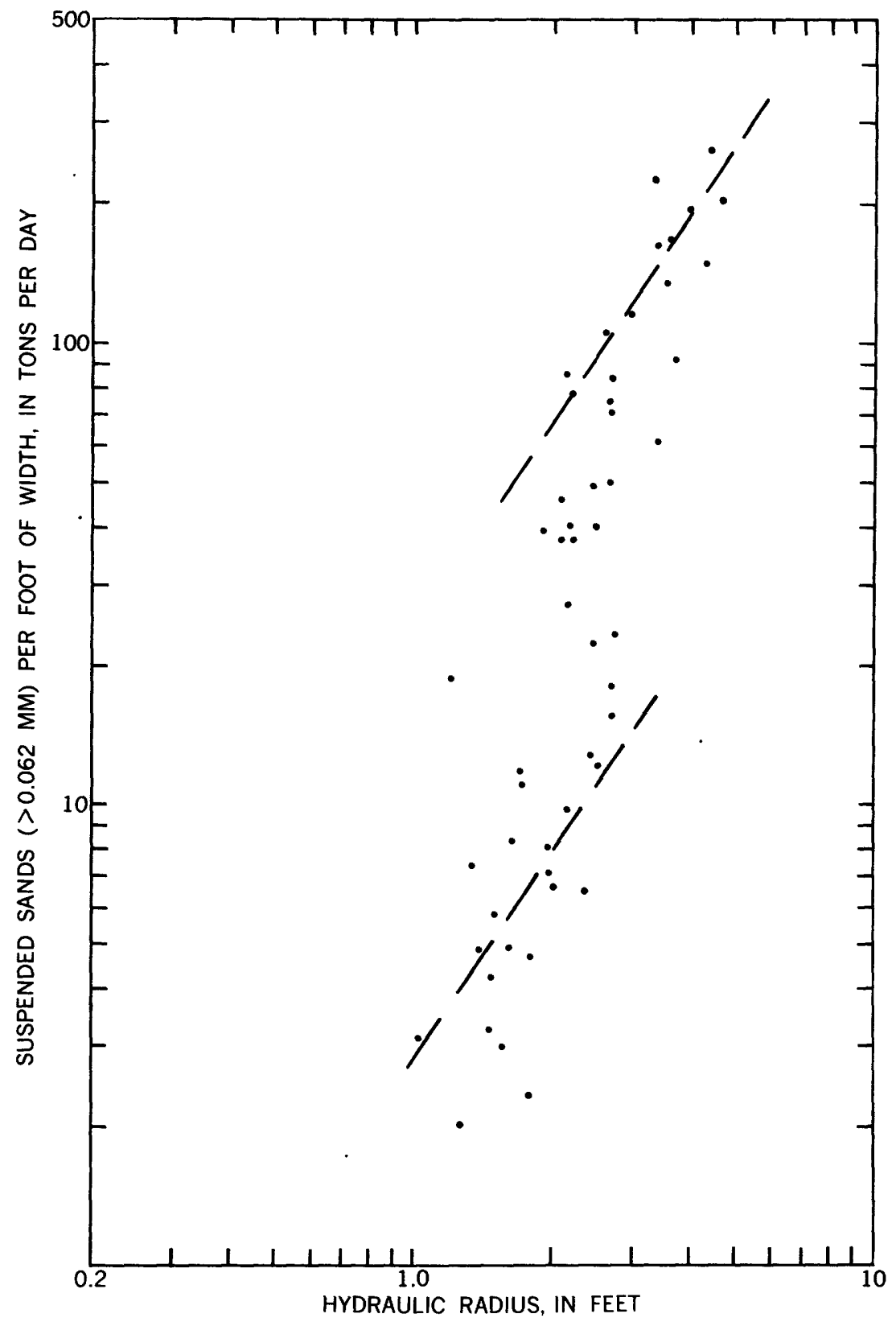

Figure 23.-Relation of suspended sanḍs to hydraulic radius for Bernalillo reach sections $A-2$ through $F$. 
FLUVIAL CHARACTERISTICS AND HYDRAULIC VARIABLES F39

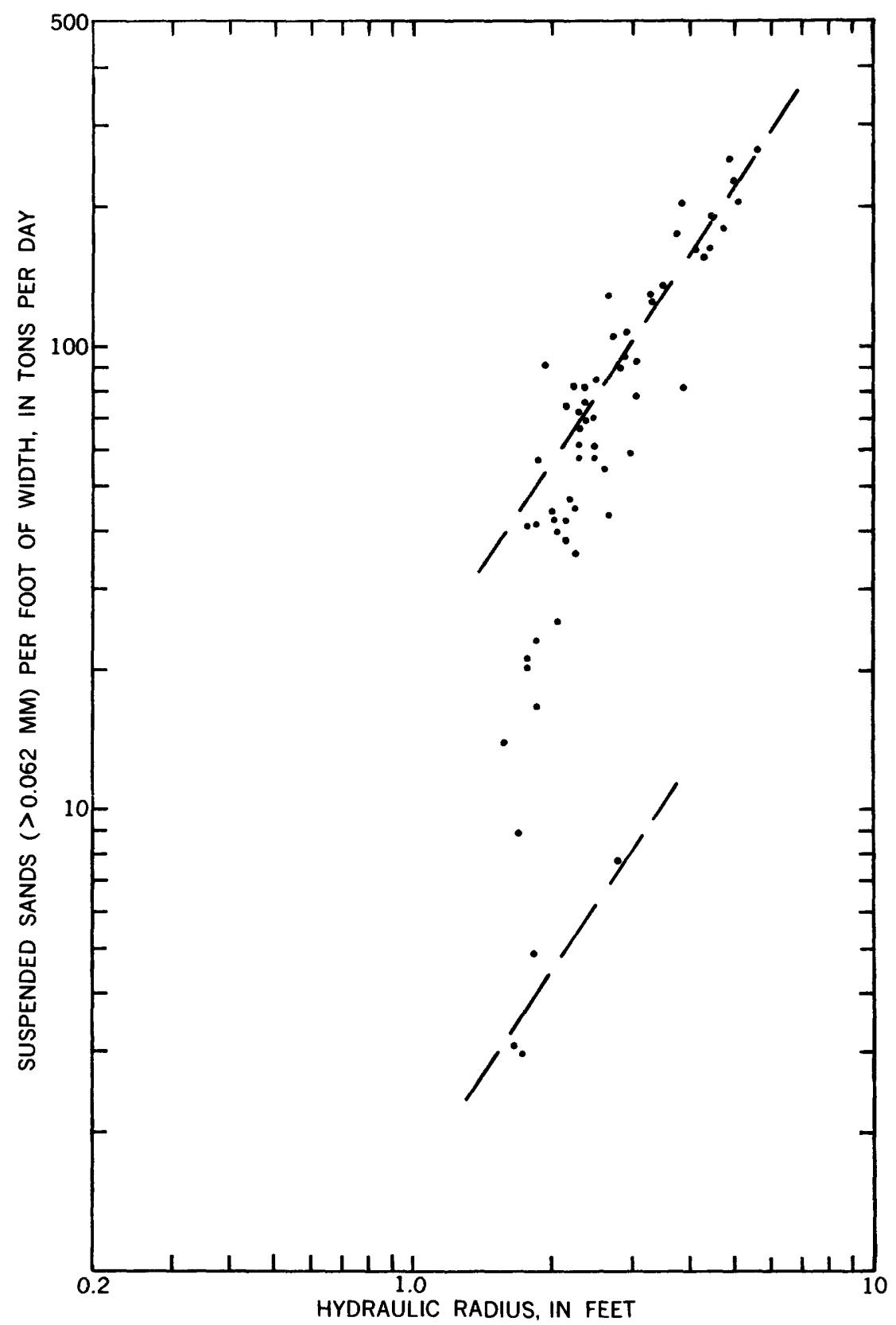

Figure 24.-Relation of suspended sands to hydraulic radius for Casa Colorada reach. 
This is the same point at which the break in the velocity-hydraulicradius relation occurs in figure 6 .

For both Bernalillo and Casa Colorada reaches, the suspended sands per foot of width varies with the three-halves power of the hydraulic radius when the flow is either in the lower regime or in fully developed upper regime.

Similar data for Rio Grande at San Antonio is shown in figure 25. The break at this station seems to occur at depths between 1.0 and 2.0 feet; however, there are insufficient data to define either the lower or upper-regime curves at this station.

Relation of suspended sands to hydraulic radius for the stations presented in these figures, as well as for other stations, have similar trends. Since, for constant slope at a station, shear has a constant ratio to hydraulic radius, the shear-transport relation would be similar to the hydraulic radius-transport relation. The Einstein and Bagnold theories attempt, a priori, to explain the differences which remain among the relations of shear to transport at the individual stations.

\section{MODIFIED EINSTEIN METHOD}

The bedload function for sediment transportation by Einstein (1950) is based on the integration of the product of the theoretical velocity and suspended-sediment concentration along a representative vertical in a cross section. The rate of movement and the concentration in the bedload layer are based on the probability that a given particle will move from its position in the streambed. The discharge of the various size ranges of the sediment are computed separately.

The Einstein transport function has been tested by field data and found considerably in error. Colby and Hembree (1955) found that the original Einstein method gave neither the correct quantity nor distribution of sizes of the transported sediment when applied to single cross sections. When applied to reaches, for which it originally was designed, it gave approximately correct totals but incorrect distribution of sizes. On the basis of measurements of suspended and total load on the Niobrara River near Cody, Nebr., a modified Einstein procedure was developed that gave fairly consistent answers at a cross section, both for total-sediment transport and for size distribution of the total sediment transported. This modified procedure was designed to use the data obtained by standard measuring and sediment-sampling equipment.

The modified Einstein method was used to compute total-sediment discharges for several stations in the middle Rio Grande. Because actual total loads were not measured at any point, the modified Einstein computations can be tested only for consistency. Both 
FLUVIAL CHARACTERISTICS AND HYDRAULIC VARIABLES F41

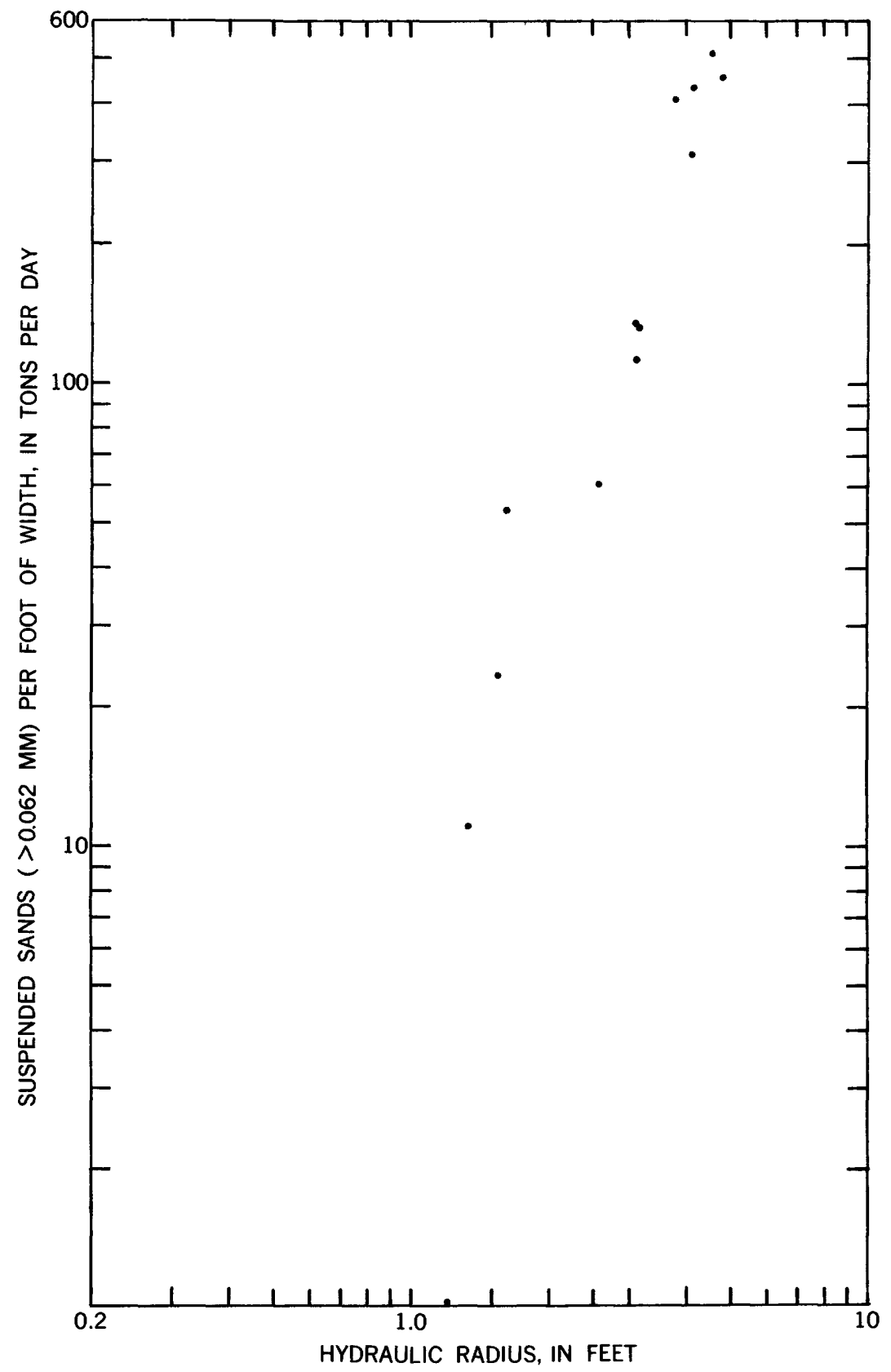

Frgure 25.-Relation of suspended sands to hydraulic radius for Rio Grande at San Antonio. 


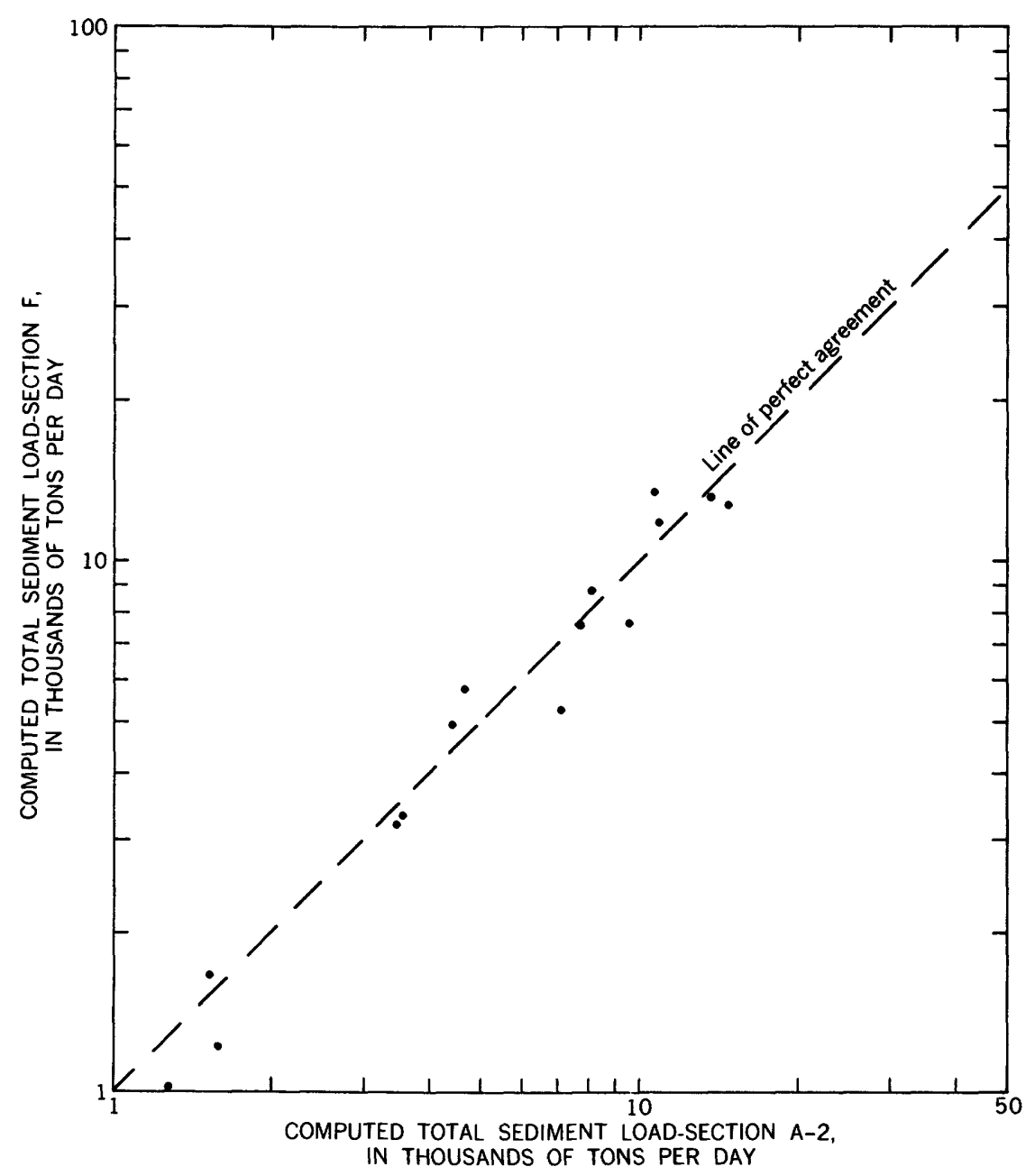

FiguRE 26.-Comparison between computed total sediment loads at Bernalillo sections $A-2$ and $F$.

suspended-sediment and computed total-sediment discharges per foot of width are listed in the tables of data for several stations.

The consistency of the modified Einstein method for computing total loads in the sand-bed channels of the Rio Grande basin is indicated in figure 26. Computed total loads for two stations, Bernalillo section $A-2$ and Bernalillo section $F$, are compared. Section $F$ is 8,240 feet downstream from section $A-2$. Section $A-2$ is deeper and maintains a constant width, whereas section $F$ is more shallow with variable widths through the range of discharges observed. Actual total loads are assumed to be equal at the two sections during the period of observation for each run. The difference between the com- 
puted total load and the measured suspended load varies from 13 to 60 percent of the computed total load. Although there is considerable scatter of the points, there is a reasonable agreement between the two sections. This indicates that for sand-bed streams in the Rio Grande basin the modified Einstein method may be expected to give reasonably consistent results regardless of width to depth relations.

The modified Einstein computations indicate that the percentage difference between suspended and computed total discharges for all stations covered in this report varies from 3 to 60 percent. The lower percentages are associated with high concentrations of fine sediment. Unmeasured load computed by the modified Einstein method is closely related to both velocity and suspended-sediment concentration, because these are the two principal variables in the Einstein transport function.

\section{BAGNOLD THEORY}

Bagnold (1956) has developed a theory that not only predicts a relation of transport function to shear function for materials of uniform grain size, but which also predicts the relation quantitatively. Although uniform sands do not exist in the field, many of the ideas presented may be helpful in understanding field conditions. This section will explore some of the ideas presented by Bagnold, attempt to consider their applicability in the field, and, within the limits imposed by the data, test his transport-shear relation with the Rio Grande data.

Bagnold tested the transport function by synthesizing data using very light water driven particles, natural river sands, windblown sands, and experimentally derived shear variables into a single transport equation. Bagnold's effective characteristic applied tangential stress contains the usual fluid shear minus critical shear, but this is modified by adding an intergranular stress, based upon experiment (Bagnold, 1955). The transport function is composed of two parts, a bedload transport function, $\phi_{b}$, and a suspended-load transport function, $\phi_{s}$.

By assuming the energy distribution is such that the work rate represented by $\phi_{s}$ is equal to that represented by $\phi_{b}$, Bagnold derives-

$$
\begin{aligned}
& \phi_{s}=\phi_{b}\left(B_{s} / B_{b}\right) \\
& \phi_{t}=\phi_{b}\left(1+B_{s} / B_{b}\right)
\end{aligned}
$$

where $-\phi_{b}=$ bedload transport function

$\phi_{s}=$ suspended transport function

$\phi_{t}=$ total transport function

$B_{s}=$ dimensionless part of $\phi_{s}$

$B_{b}=$ dimensionless part of $\phi_{b}$. 


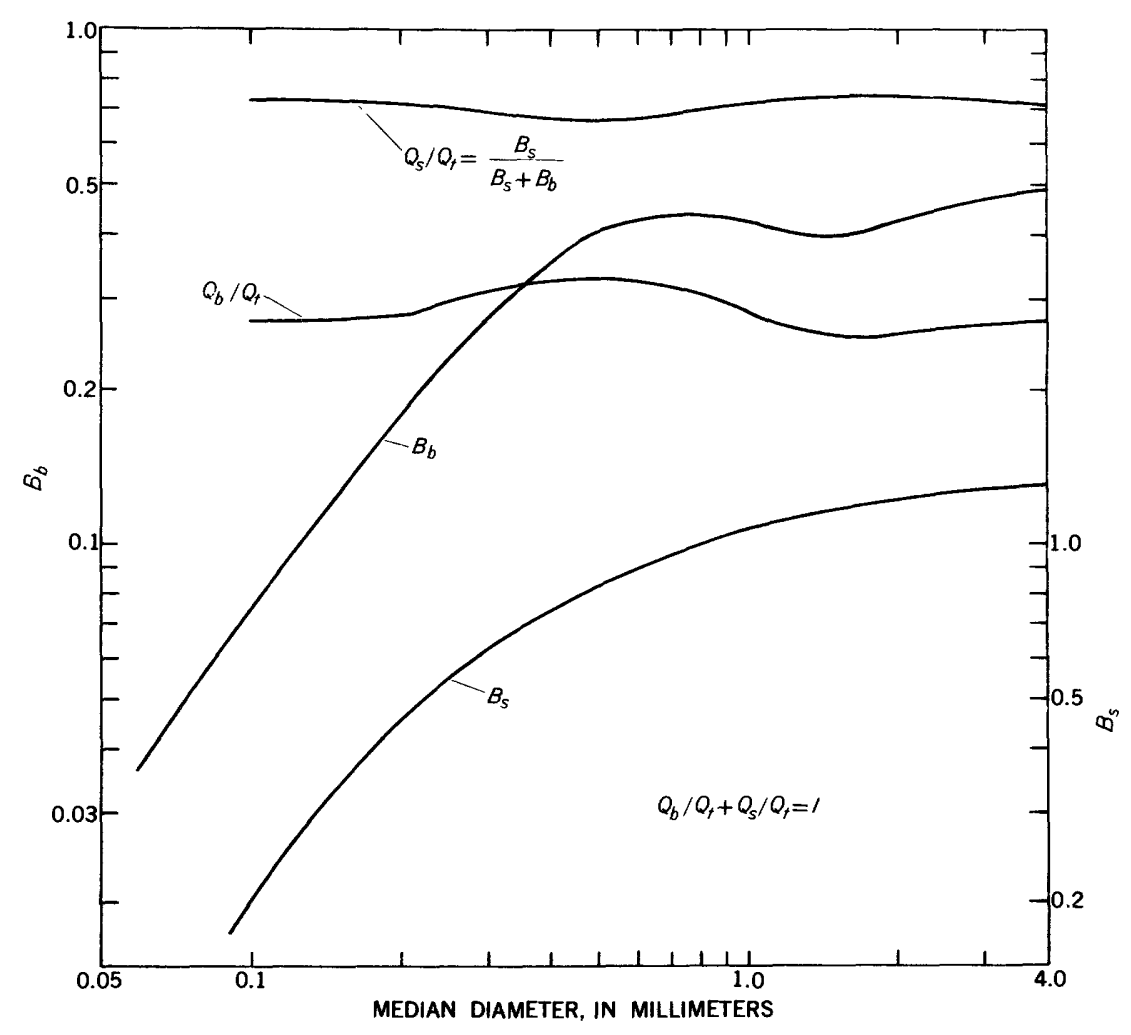

FiquRe 27.-Relation between median diameters, $\boldsymbol{B}_{\mathbf{a}}$ and $\boldsymbol{B}_{\mathrm{b}}$.

The dimensionless part of $\phi_{b}, B_{b}$, is constant for a given grain size, or median diameter of bed material. Values of $B_{b}$ experimentally determined by Bagnold are shown in figure 27. The dimensionless part of $\phi_{s}, B_{s}$, is a function of the velocity of the sediment in suspension. Where the product of velocity of flow and slope is much smaller than the fall velocity of the median bed-material particle, $B_{s}$ becomes constant (fig. 27). If $B_{s}$ and $B_{b}$ are constant for a given bed material, then $\phi_{s}$ is proportional to $\phi_{b}$, and $Q_{s}$ is proportional to $Q_{b}$. In fact-

similarly-

$$
\phi_{s}=\frac{B_{s}}{B_{b}+B_{s}} \phi_{t}
$$

$$
Q_{s}=\frac{B_{s}}{B_{b}+B_{s}} Q_{t}
$$

Thus, for sufficiently large sediment, flat slopes, and relatively slow velocities, the suspended-sediment transport, $Q_{s}$, could be adjusted by a constant factor to obtain total sediment transport, $Q_{\imath}$. 
These conditions are approached in the field, because the slopes generally are flat in relation to those used in laboratory flume studies. Therefore, by logical inference from the Bagnold theory, when these conditions exist it is sufficient to measure the suspended-sediment load in order to obtain the total sediment load.

\section{THE BAGNOLD PLOT}

The Bagnold transport and shear functions were computed for each station and are shown in the tables of data. The total-transport function was computed from the Bagnold equation

$$
\phi=q_{s} / b g \rho_{s} d B_{b} \sqrt{\Delta \gamma_{s} d / \rho} .
$$

Since only suspended load was measured, for the purpose of this report, this equation reduces to the form

$$
\phi=0.0514 C_{T} Q / B_{b} b d^{3 / 2}
$$

where $C_{T}=$ measured ppm $>0.062 \mathrm{~mm}$ by weight in suspension. Thus, all values of $\phi$ computed for this report differ from the total $\phi$ in the same degree that measured suspended load differs from total load.

The characteristic applied tangential stress values were computed as-

$$
\theta=\alpha D S / \Delta \alpha_{s} d+D \bar{C} S / d
$$

which reduces to- $\theta=\left(0.606+0.378 C_{m}\right) D S / d$

where $\bar{C}=$ measured ppm by volume in suspension and $C_{m}=$ measured ppm by weight in suspension.

A combined plot of all the Rio Grande data is shown in figure 28. Some data from USGS flume experiments also are included on the figure. The dashed lines show what Bagnold has predicted to be the transport-shear relation. The three sets of solid lines show what appear to be trends for the field data presented. Although the points do not follow Bagnold's predicted relation, the $\phi$ for individual stations does vary with $\theta^{3 / 2}$. To illustrate this, the data for the Casa Colorada reach is plotted separately in figure 29. The data for this reach covers both lower and upper regimes of flow and the relation is well defined.

The fact that field data on natural streams do not follow closely relations derived from theory and laboratory experiments is not too disturbing. Determination of basic principles governing natural phenomena must be derived from theory or from the laboratory, where sufficient control and accuracy of measurement can be accomplished. Ultimately, however, theoretical relations between 


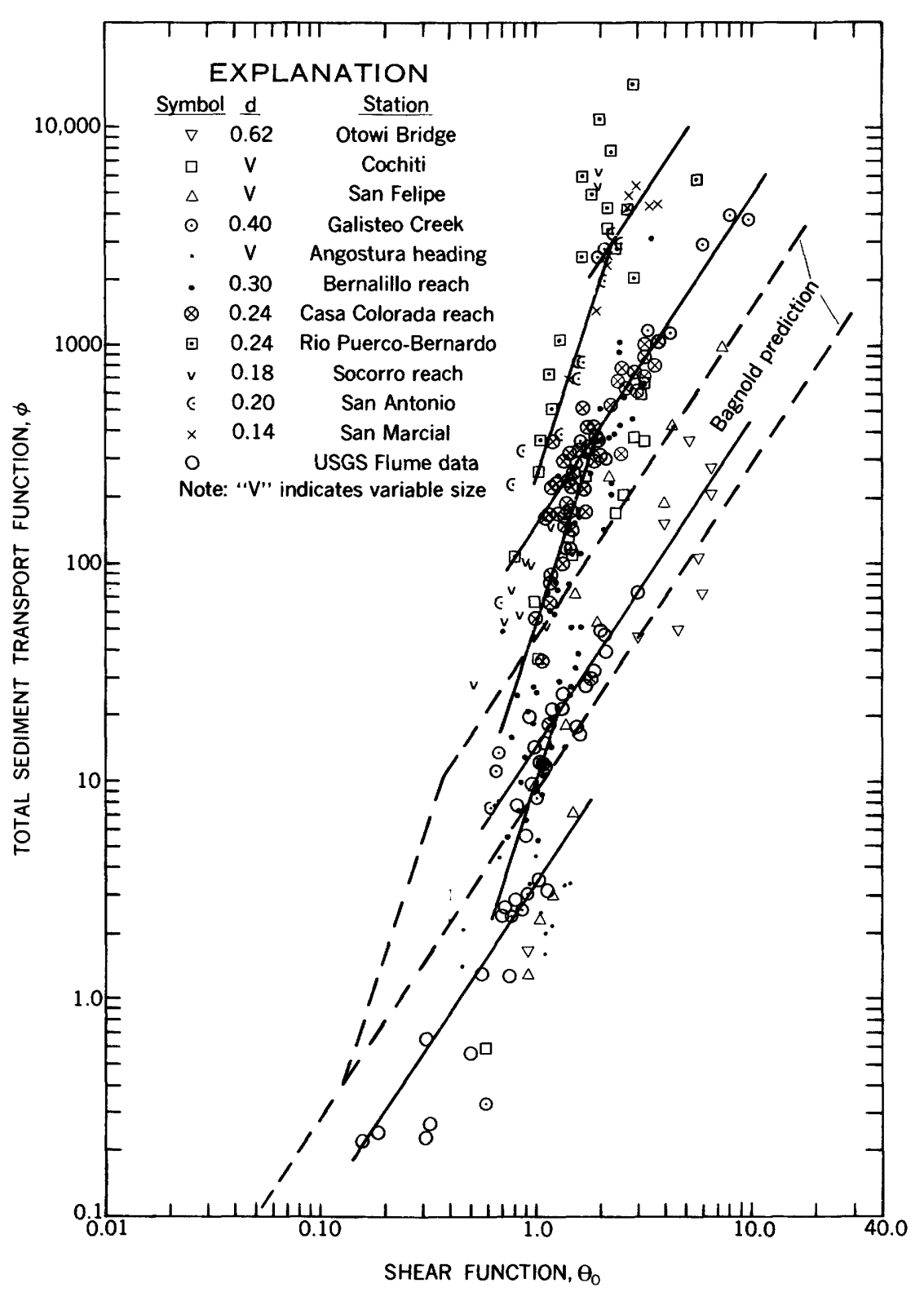

Figure 23.-Bag nold plot of Rio Grande data.

variables must be tested and proven by application of field data. Several theories and assumptions incorporated in the Bagnold theory theory can now be examined more closely in view of the field data presented. 
FLUVIAL CHARACTERISTICS AND HYdRAULIC VARIABLES F47

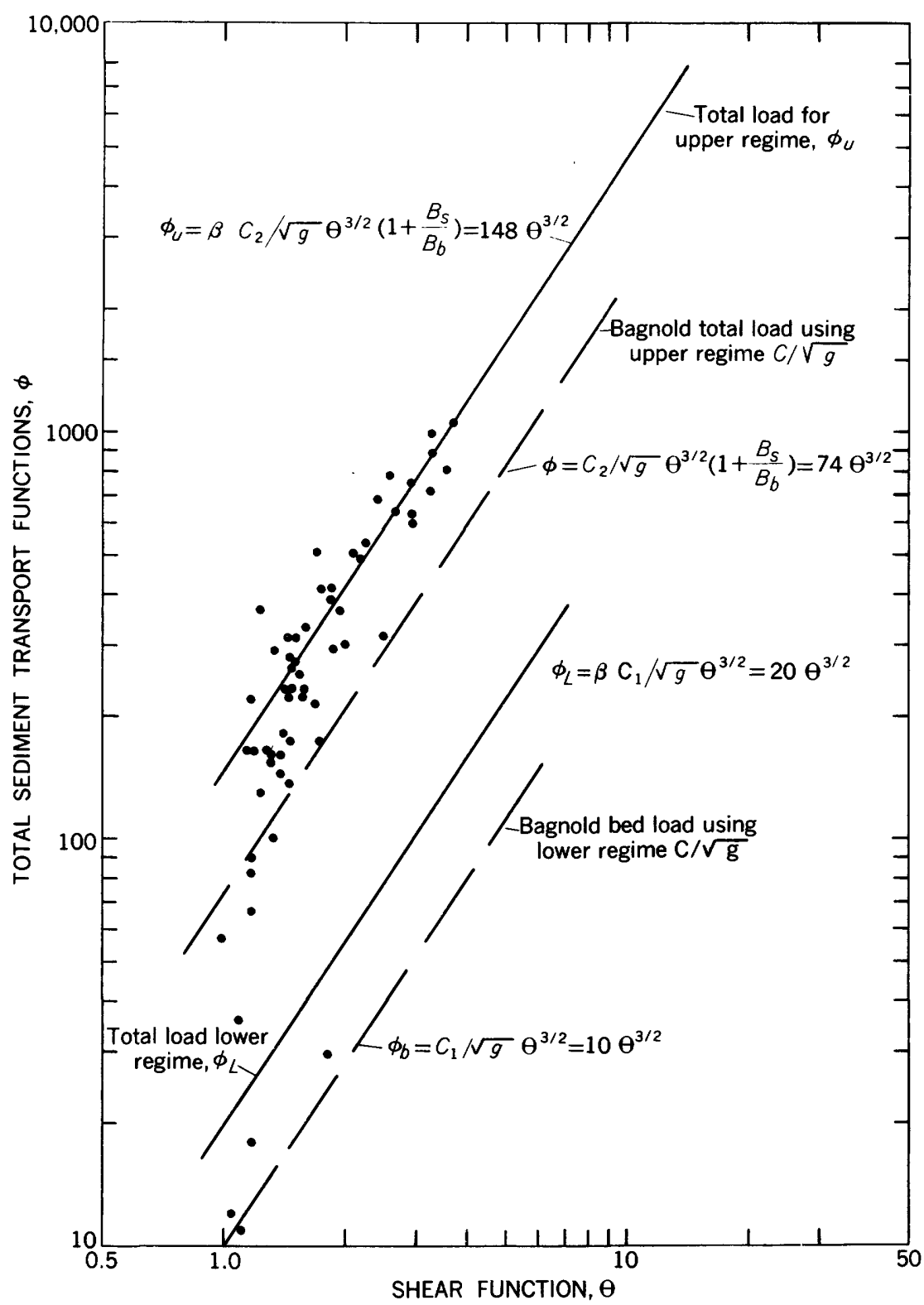

Figure 29.-Bagnold relation for Casa Colorada reach.

CRITICAL STRESS $\theta \approx 0.4$

Bagnold hypothesized that, at the theoretical tangential fluid stress $\theta \approx 0.4$, the boundary conditions of the fluid changes from a fixed boundary of granular roughness to a zone of moving bed-material 
particles. He assumes that the transition from bedload movement only is complete at the critical stress of $\theta \approx 0.4$, and therefore, that the suspended load is fully developed at this stress. In other words, Bagnold explained this transition as entirely due to the development of a suspended load. Analysis of field data seems to indicate that this transition may be explained more accurately as due to a change from lower- to upper-regime flow.

Bagnold's data included only flume data in which total load was measured at the outfall. There was no direct measurement of suspended load or bedload. Any such subdivision of the measured total load is hypothetical for these data.

Further, it appears that the tangential stress at which the change from lower to upper regime occurs is variable. This is verified by field data (fig. 28) and laboratory studies at Ft. Collins (Richardson, 1960). As an example, data for the Rio Grande near Bernalillo reach indicate the change from lower to upper regimes to be complete at a tangential stress of approximately $\theta \approx 2.0$, whereas the Casa Colorada reach data show the change completed at $\theta \approx 1.5$. Because Bagnold's data was for more nearly uniform grain sizes than are found in the field, the dominant size from which to compute $\theta$ is debatable. Both the difference from the predicted value of 0.4 and the variation among stations may be the result of using the median diameter as the dominant diameter.

However, the plotting of the data for each individual station indicates a relatively stable dominant diameter should be used. The difficulty of the determination of the dominant diameter of the material available for transport may be one of the causes for the variation of the station plots from the predicted relation but cannot be the sole cause. Because the dominant diameter appears both in the shear and the transport terms, any change in the dominant diameter would be minimized in the resulting plot. The main effect would be in determination of the tangential stress at which the change in regime takes place.

\section{CHARACTERISTIC APPLIED TANGENTIAL STRESG}

It becomes evident that, as Bagnold intimated, the additive term $D S \bar{C} / d$ in the shear function

$$
\theta=\gamma D S / \Delta \gamma_{s} d+D S \bar{C} / d
$$

becomes negligible in the stream case. Run No. 15 for Bernalillo section $A-2$ shows a concentration by weight of $5,980 \mathrm{ppm}$, a depth 
of 2.96 feet, a slope of $0.00095 \mathrm{ft}$ per $\mathrm{ft}$ and a median bed-material diameter of 0.00098 feet. Therefore,

$$
\begin{aligned}
\theta & =(62.4 / 103+0.00598 / 2.65) \frac{2.96 \times 0.00095}{0.00098} \\
& =1.74+0.0065 \\
\text { or- } \quad \theta & =1.75
\end{aligned}
$$

Without this additive term, the tangential stress becomes mainly

$$
\theta=\gamma D S / \Delta \gamma_{s} d \text { or } \tau_{o} / 103 d \text {. }
$$

The bedload equation of Meyer-Peter, Kalinske, and Einstein can be expressed as a function of this same tangential stress parameter. Thus, for actual streams the additive parameter for effect of concentration in the stress function proposed by Bagnold is not sufficient to bring field data to a single relation.

\section{TOTAL TRANSPORT FUNCTION, $\phi$}

According to the a priori relation hypothesized by Bagnold, at $\theta=0.4$ both the suspended-load function and the bedload function become proportional to $\theta^{3 / 2}$, and the total-load equation

$$
\phi=9 \theta^{3 / 2}\left(1+B_{s} / B_{b}\right)
$$

becomes applicable. Thus, the total-load function, $\theta$, becomes proportional to $\theta^{3 / 2}$.

The coefficient, 9, was an experimental estimate of the velocity term in the Keulegan velocity equation, derived theoretically as 8.5. It represented the ratio of the velocity of flow at a distance of one grain layer above the bed to the shear velocity. In place of this coefficient can be substituted $V / V_{*}$ which equals $C / \sqrt{g}$ (Bagnold 1960). This converts the shear parameter to the equivalent of a stream power. Thus, the a priori relation can be written-

and-

$$
\phi=(C / \sqrt{g}) \theta^{3 / 2}\left(1+B_{s} / B_{b}\right)
$$

$$
\phi_{b}=(C / \sqrt{g}) \theta^{3 / 2} \text {. }
$$

Because the Chezy $C$ varies with median diameter of bed material for upper regime flows, there should be no unique relation between $\phi$ and $\theta^{3 / 2}$. Not only does $C / \sqrt{g}$ vary from station to station, depending upon bed material, but even more important, $C / \sqrt{g}$ varies at a station depending on regime of flow. Because this is so, the ratio $\left(1+B_{s} / B_{b}\right)$, is not a sufficient correction for Bagnold's relation. An additional correction must be made for the changing $C / \sqrt{g}$ with change in regime. 
The relation computed from average $C / \sqrt{g}$ values for lower and upper regimes are shown for the Casa Colorada reach in figure 29. Data for suspended load for lower regime seems to equal the Bagnold relation for bedload. If Bagnold's bedload is correct, this would indicate that total load for the data included in this report is about twice the suspended load for lower-regime flows. The curve computed from $C / \sqrt{g}$ values for upper-regime flows (fig. 29) does not equal the plot of the suspended-load field data, but rather, gives values of $\phi$ approximately half the measured suspended load. D. B. Simons (oral communication) indicates, on the basis of flume studies, that current sediment-sampling techniques tend to measure larger percentages of total load than is realized. In fact, for upper-regime flows, measured suspended load approaches, and for antidune conditions equals, total load. This may be the case for the Casa Colorada reach.

Assuming this is the case, then it seems that Bagnold's ratio $\left(1+B_{s} / B_{b}\right)$, is approximately correct for difference between total load for lower and upper regimes if a correction for the changing $C / \sqrt{g}$ is included. This seems to indicate, once again, that Bagnold's explanation of the two curves as a bedload-total load relation is truly a phenomenon of a lower-regime, upper-regime relation. His critical $\theta$, the shear at which he predicts a fully developed suspended load, probably is the $\theta$ at which upper-regime flow becomes fully developed.

Since $C / \sqrt{g}$ for upper regimes does vary between stations depending upon size of bed material, there should be no unique relation for total load as indicated by Bagnold. However, if measured suspended load for the upper regimes does approximate total load as hypothesized by Simons, Bagnold's relation might be used to predict total load in the lower regimes. Figure 29 shows that this relation might apply. If Bagnold's relation is in error by a scale factor, $\beta$ (see fig. 29), then total load for the upper regime equals

$$
\phi=\beta\left(C_{2} / \sqrt{g}\right) \theta^{3 / 2}\left(B_{b}+B_{s}\right) / B_{b}
$$

The lower-regime total load is found by multiplying the upper-regime load by the adjustment ratio

$$
\left(C_{1} / C_{2}\right) B_{b} /\left(B_{b}+B_{s}\right)
$$

thus, the lower regime total load, as expected, would be

$$
\beta\left(C_{1} / \sqrt{g}\right) \theta^{3 / 2} .
$$


Both upper- and lower-regime total loads should be in error by the same scale factor if our interpretation of Bagnold is correct.

For the Casa Colorada reach, this scale factor, $\beta$, is equal approximately to two.

Colby (1957) and others stated that total load is related to the cube of the mean velocity. If this is so the adjustment ratio for lower- to upper-regime loads $\left(1+B_{s} / B_{b}\right)\left(C_{2} / C_{1}\right)$, should be predictable from the depth-velocity relation. For a given depth in the Casa Colorada reach, the velocity approximately doubles during the change from lower- to upper-regime flows. Therefore,

$$
\left(1+B_{s} / B_{b}\right)\left(C_{2} / C_{1}\right)=2^{3}=8 .
$$

For the Casa Colorada reach, the actual values indicate

$$
\left(1+B_{s} / B_{b}\right)\left(C_{2} / C_{1}\right)=(3.41)(22.2 / 10.0)=7.6 .
$$

In conclusion, it appears that field data do not follow the single functional relation proposed by Bagnold. The major discrepancies stem partly from experimentally determined variables relative to effects of concentration on the shear function. The unknown relations between model and prototype in sediment-transport studies also add considerably to the discrepancies. Also, shear stresses obtained in the laboratory flume with small depths and large slopes do not produce the same sediment-transport shear relation as do shear stresses resulting from greater depths and lesser slopes that occur in the field.

\section{COMPARISON BETWEEN MODIFIED EINSTEIN AND BAGNOLD}

The Bagnold computations of total sediment load are based on sand sizes only, as shown in a previous section. Modified Einstein computations may be compared with Bagnold computations for consistency by plotting modified Einstein computed total sand loads against the Bagnold $Q_{t}$. This has been done in figure 30 using the Rio Grande data presented in this report. There is considerable scatter in the plot in the range of values less than about 300 tons per day per foot of width. In this range the plot indicates, generally, greater computed sand loads by the Einstein method. For more than 300 tons there seems to be reasonable agreement between values computed by the two methods.

A more practical plot is shown in figure 31 . The load of fine material (finer than $0.062 \mathrm{~mm}$ ) is simply added to both modified Einstein and Bagnold computed total-sand loads. This plot thus represents a comparison of total-sediment transport between the two methods. A single line of perfect agreement can be drawn for values more than 


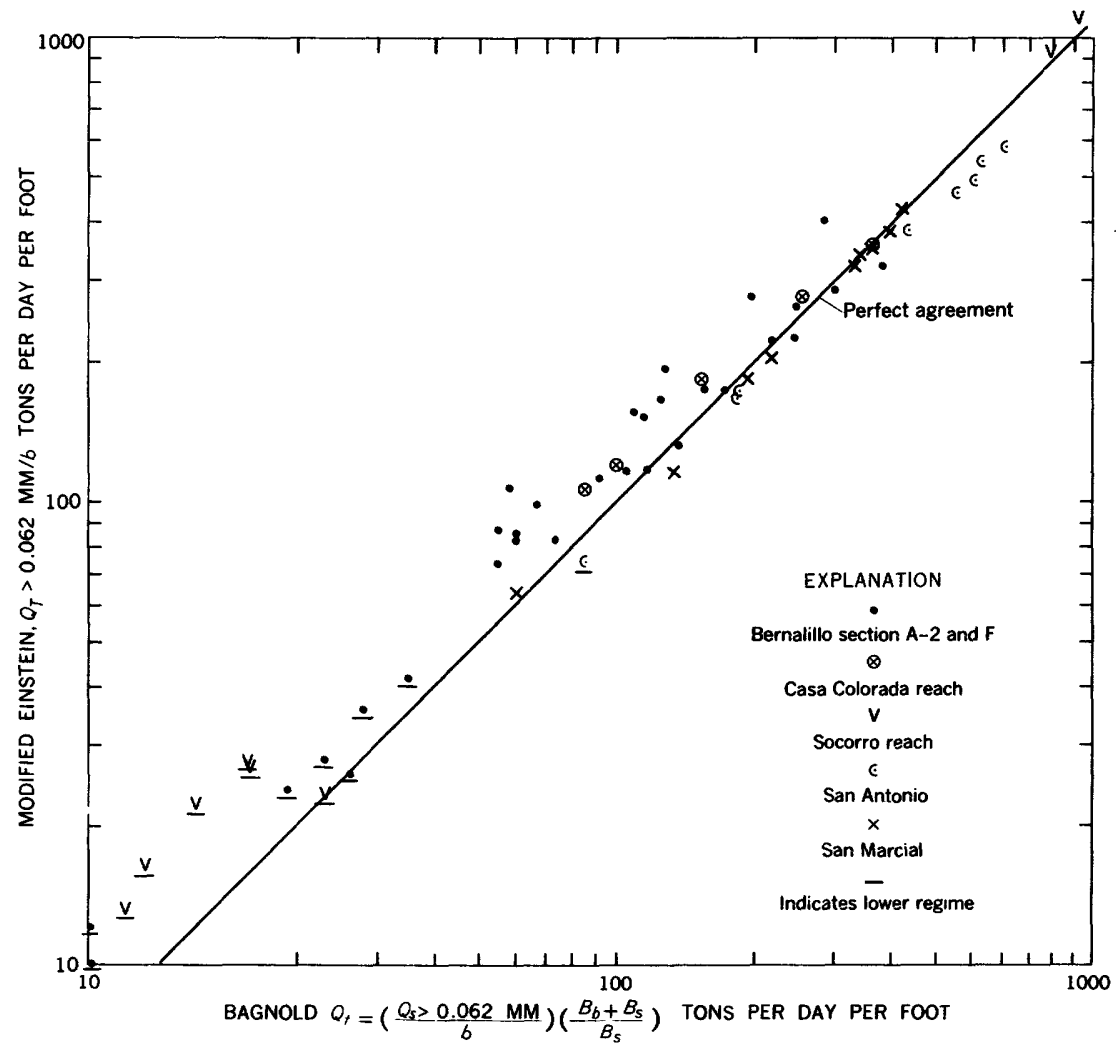

Figure 30.-Comparison of Bagnold and modified Einstein computed total sands.

about 300 tons per day per foot of width. Below this point the modified Einstein values are greater by about 15 percent, and the deviation from this relation is indicated on the plot by lines at plus and minus 10 percent.

The 300-ton point at which the two methods predict equal total loads cannot be explained on the basis of flow regime. That is, the 300-ton point is not that point separating lower and upper flows. Lower-regime flows seem to break to upper-regime flows at about 100 tons per day per foot of width for the data presented. It seems reasonable to believe that with more than 300 tons the entire cross section of flow may be in fully developed upper regime, whereas in the range between 100 and 300 even though average values of velocity and depth indicate upper regime, some part of the cross section remains in transition or lower regime. 
FLUVIAL CHARACTERISTICS AND HYDRAULIC VARIABLES F53

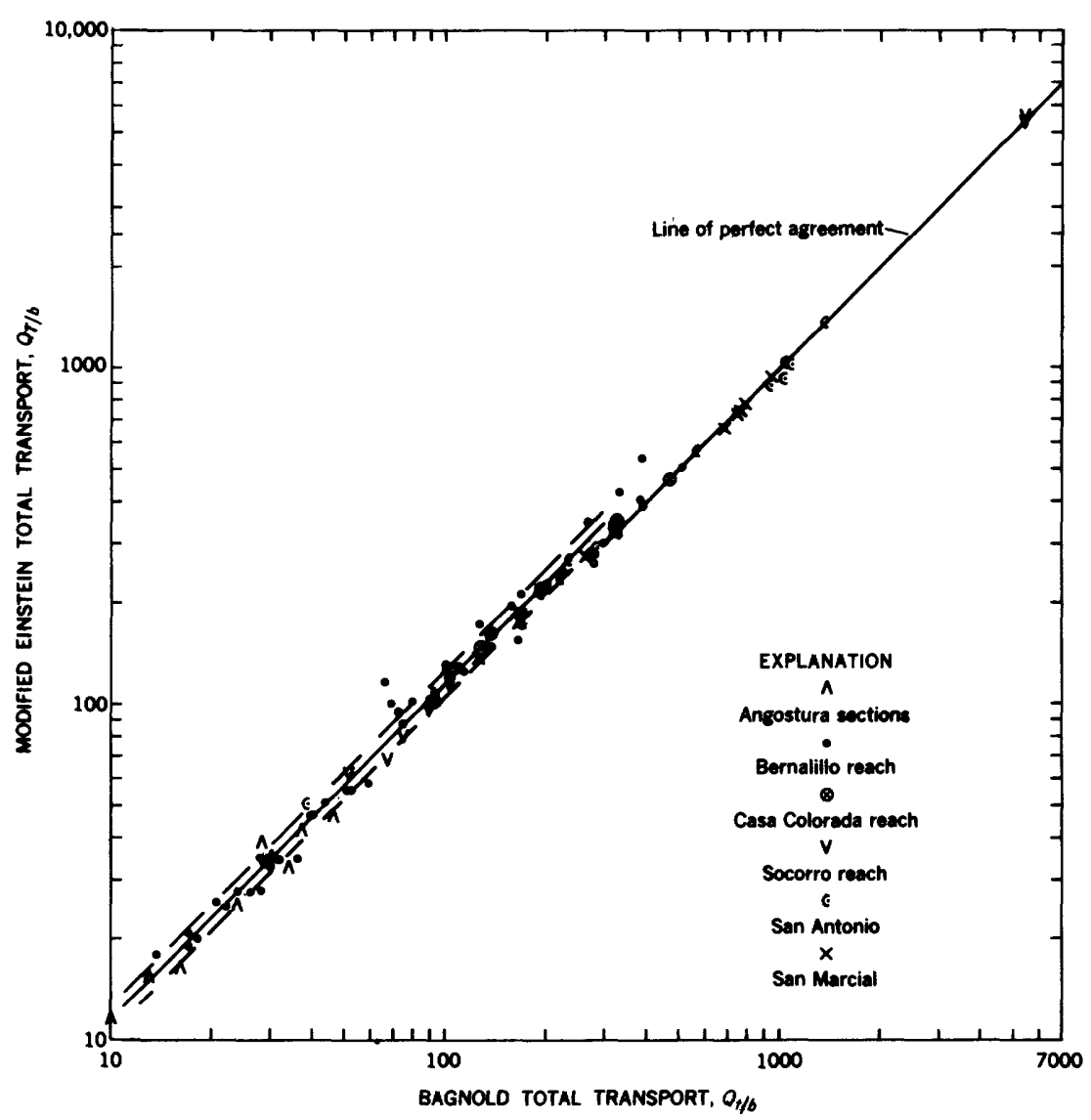

Figure 31.-Comparison between modified Einstein and Bagnold total transport.

\section{CONCLUSIONS AND SUMMARY}

That part of the middle Rio Grande from the Angostura diversion dam to San Marcial can be defined principally as a sand-bed channel. In this reach, change from lower regimes of flow to upper regimes of flow is accompanied by a change in stream velocity and sedimenttransport characteristics. When transition from lower regime to upper regime is complete, velocity is approximately doubled and sedimenttransport capacity for material available in the channel is increased about 8 to 10 times.

For this sand-bed channel reach, the plane bed before movement, ripple, and dune regimes of flow seem to produce similar relations between velocity and hydraulic radius and between suspended sands and hydraulic radius and, therefore, can be considered as a single lower regime. The plane bed, or flat bed, standing wave, and antidune regimes of flow similarly can be considered as a single upper regime. 
The discontinuity, or break, occurs in the transition regime between the lower and upper regimes.

Energy slopes at stations remained virtually constant with change in discharge for the range in discharge studied. The average of all observed water-surface slopes through the range in discharge studied equaled the energy gradient through the Bernalillo and Casa Colorada reaches. The average of observed water-surface slopes for each station can be used as energy slope in computations of all flow and transport parameters.

Analysis of bed-material samples taken upstream from the Angostura diversion dam indicates bimodal size distribution and wide variation in median diameter with discharge. Channels with these bedmaterial characteristics are defined in this report as sand-gravel channels. Analysis of bed-material samples taken at locations downstream from Angostura heading in the middle Rio Grande generally indicate that the median diameter does not vary appreciably with discharge. These locations are defined in this report as sand-bed channels.

Roughness in a given reach, as expressed by the Chezy $C$, is approximately constant for upper-regime flows in sand-bed channels. Chezy $C$ at a station mainly is a function of the size of bed material. The effect of the depth-roughness ratio, width-depth ratio, and suspendedsediment concentration do not appear to be significant variables in determining roughness in sand-bed channels.

In sand-bed channels, scour that occurs during high-water periods often may be local in extent. In narrow sections, the streambed scours during periods of rising flow and fills during periods of diminishing flow. In wide or expanding sections, the opposite seems to be true. This seems to be an adjustment of the stream to maintain a constant energy gradient and an approximately constant area. Because most stream-gaging stations are maintained at narrow, contracting sections, much of the evidence concerning scour and fill patterns based on gaging-station records is biased toward a belief in scouring on the rise and filling on the recession.

Computations of total sediment loads using the modified Einstein method give consistent results for the sand-bed channels of the middle Rio Grande, regardless of width-depth ratios.

Based on the rio Grande data, the new stress function proposed by Bagnold, which included the additive parameter for effect of concentration, is not sufficient to bring field data to a single relation.

For more than about 300 tons per day per foot of width, the sàme total sediment loads can be obtained by using either the modified Einstein or the Bagnold method of computation. For less than 300 tons, modified Einstein values are approximately 15 percent greater than Bagnold values. 
FLUVIAL CHARACTERISTICS AND HYDRAULIC VARIABLES F55

TABLES OF BASIC DATA AND COMPUTED PARAMETERS

TABLE 5.-Basic data and computed parameters for the Rio Grande at Otowi Bridge near San Ildefonso

[This is not a true sand-bed channel. $S=0.0021 \mathrm{ft}$ per $\mathrm{ft} ; d=0.00203 \mathrm{ft}, 0.62 \mathrm{~mm} ;\left(1+\frac{B_{b}}{B_{d}}\right)=1.47$ ]

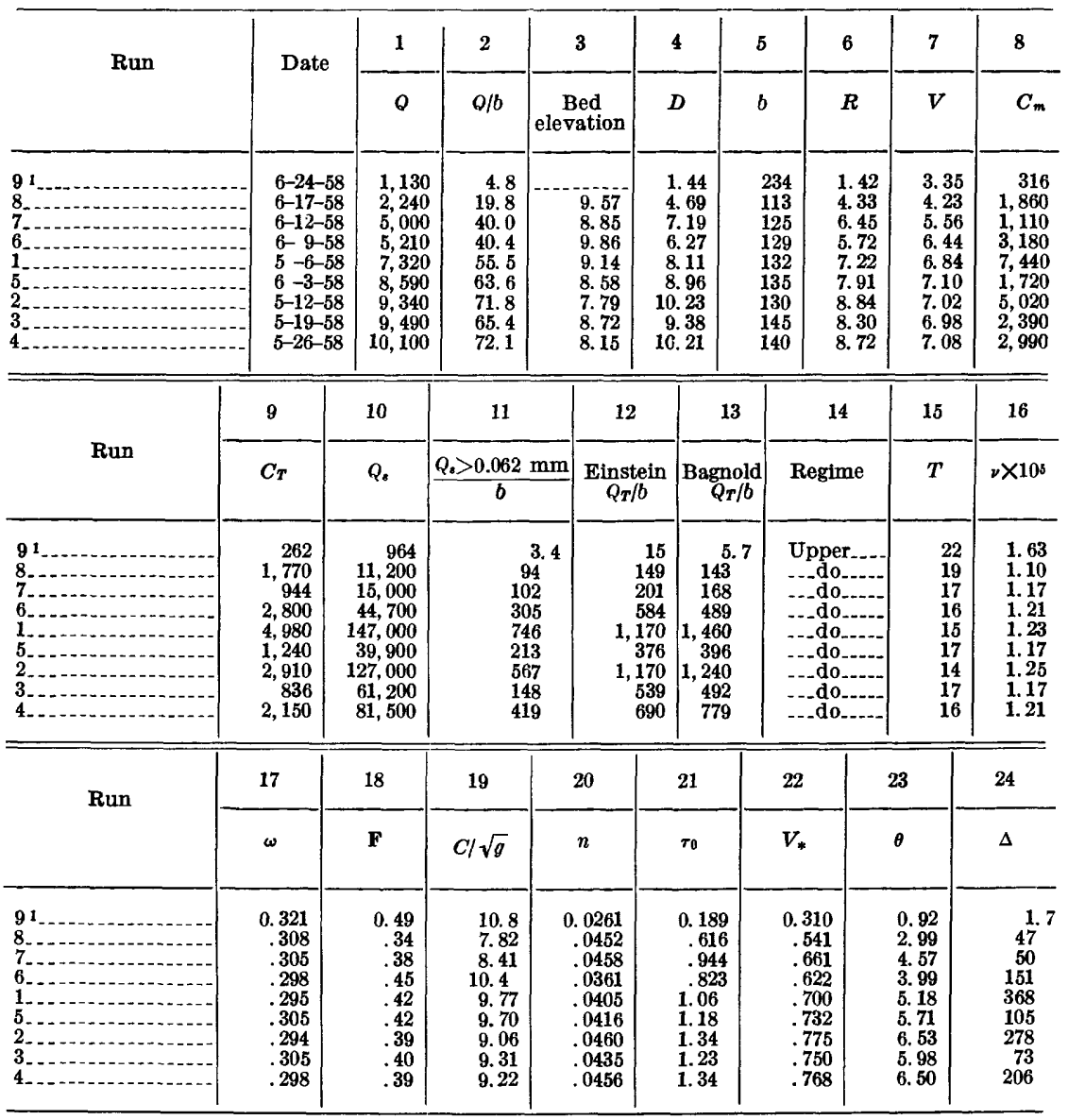

1 Run 9 not at cableway. 
TABLE 6.-Basic data and computed parameters for the Rio Grande at Cochiti [This is not a true sand-bed channel. $S=0.0012 \mathrm{ft}$ per $\mathrm{ft} ; d$, see column 25]

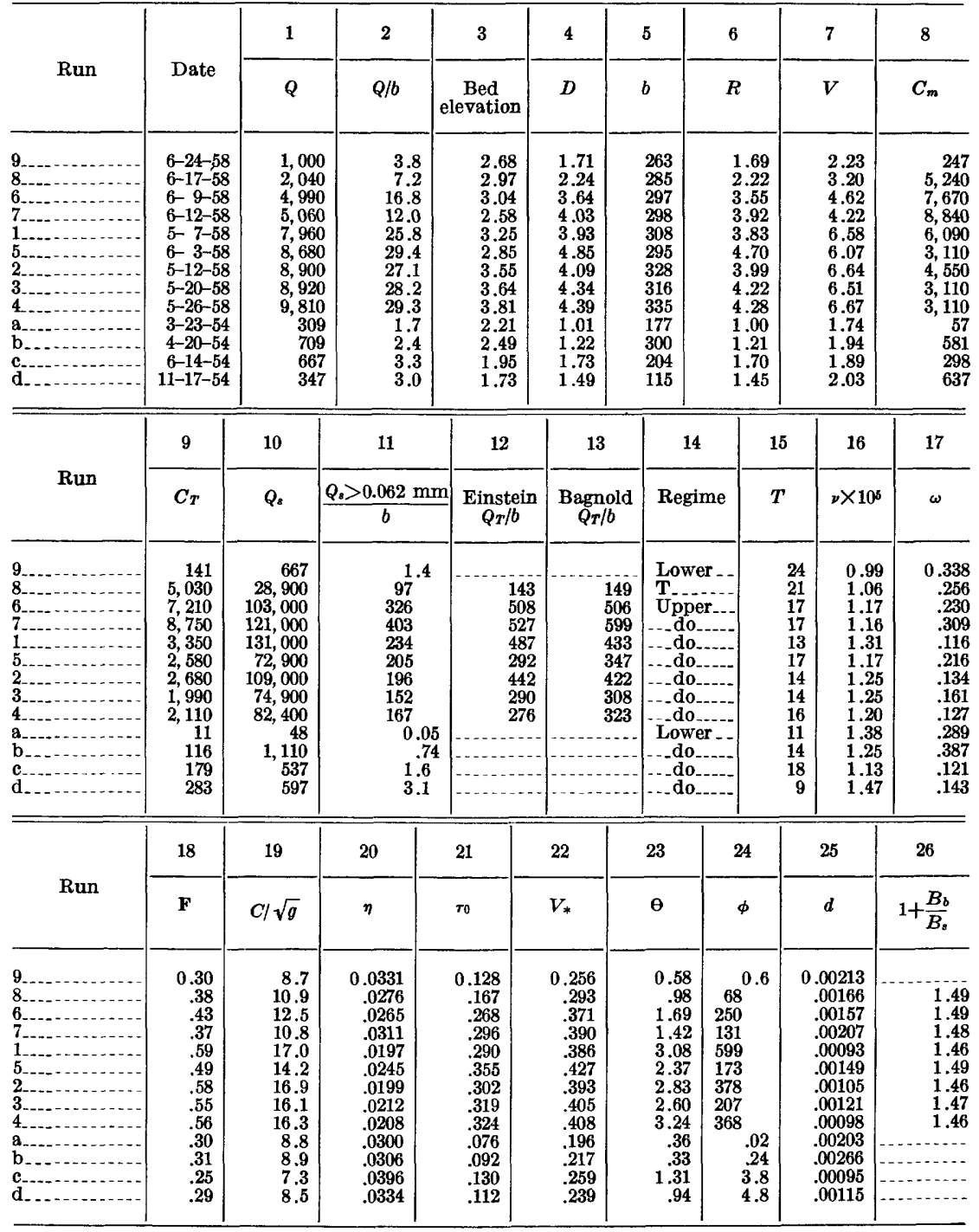




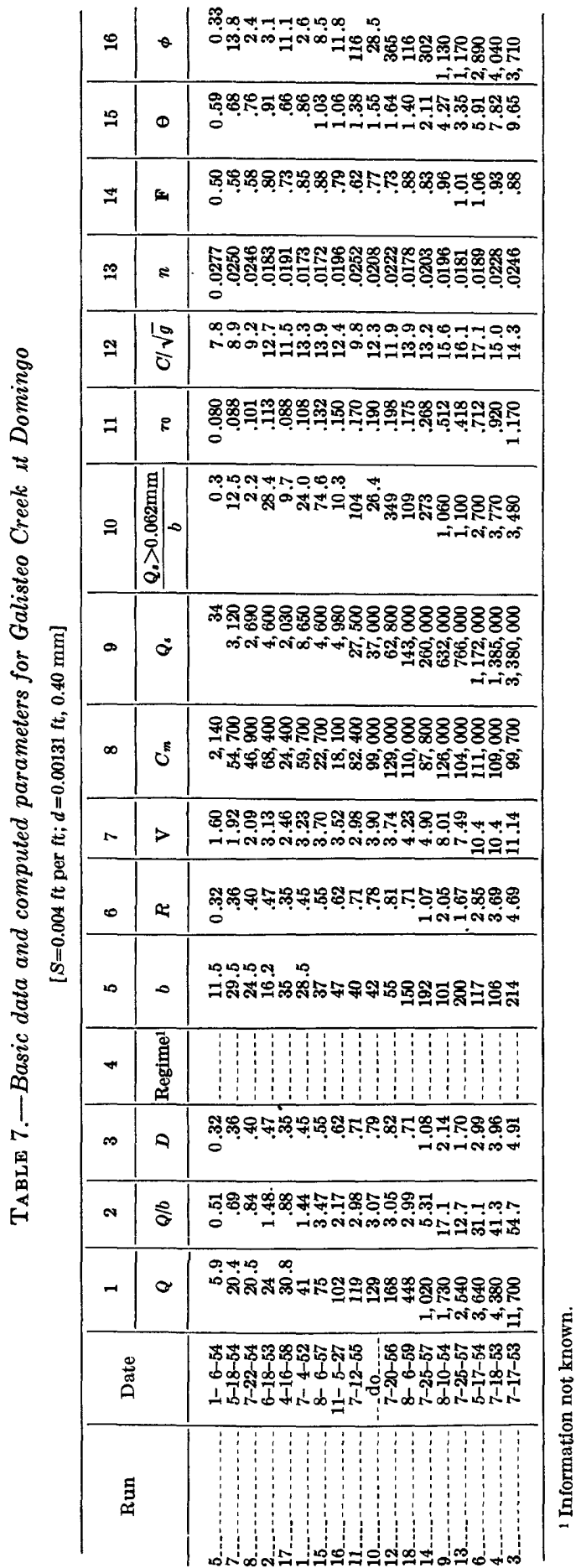


TABLE 8.-Basic data and computed parameters for the Rio Grande at San Felipe

[This is not a true sand-bed channel. $S=0.0015 \mathrm{ft}$ per ft; $d$, see column 25]

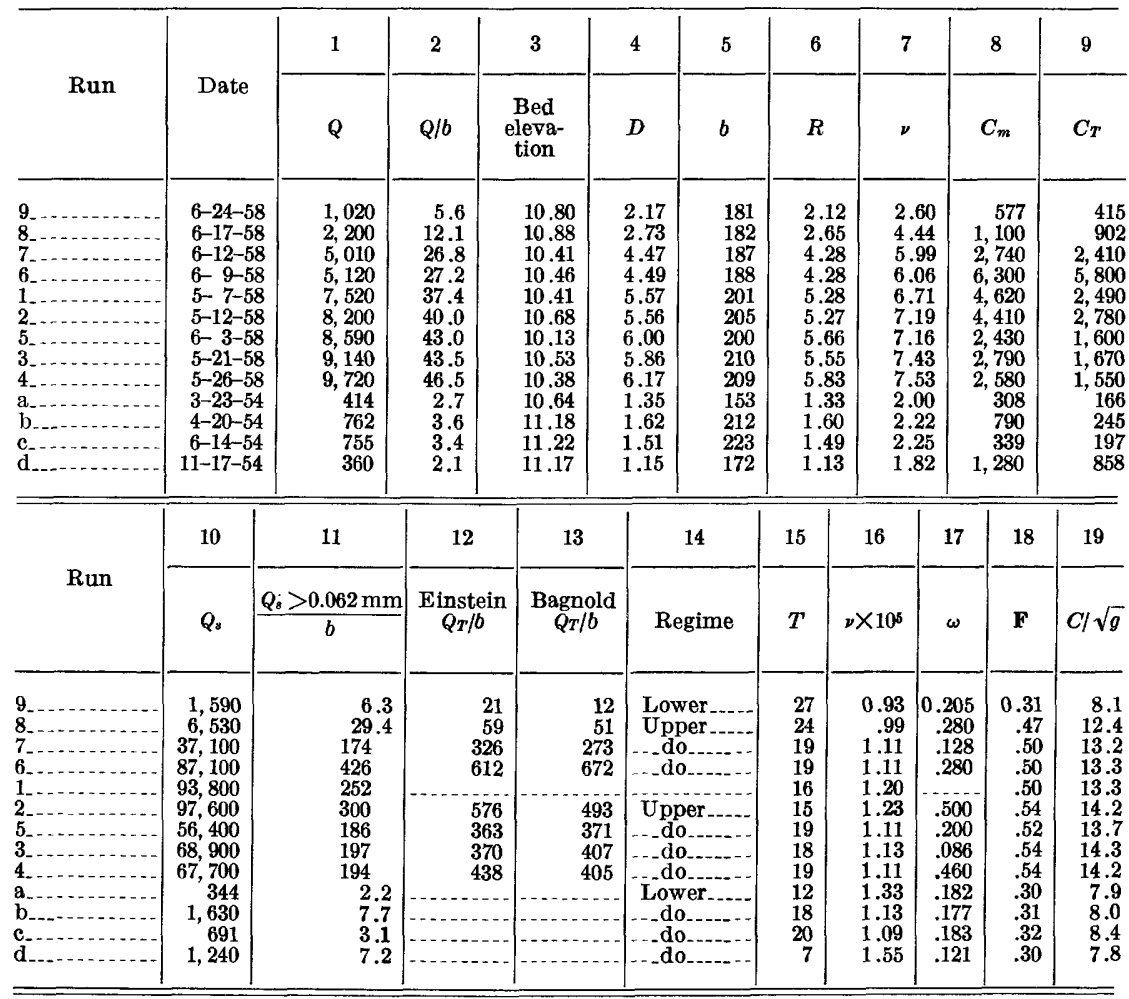

\begin{tabular}{|c|c|c|c|c|c|c|c|}
\hline \multirow{2}{*}{ Run } & 20 & 21 & 22 & 23 & 24 & 25 & 26 \\
\hline & $n$ & $\tau_{0}$ & $V_{*}$ & $\boldsymbol{\theta}$ & $\phi$ & $d$ & $1+\frac{B_{b}}{B_{s}}$ \\
\hline 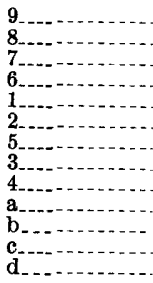 & $\begin{array}{r}0.0375 \\
.0257 \\
.0254 \\
.0261 \\
.0272 \\
.0254 \\
.0268 \\
.0254 \\
.0259 \\
.0354 \\
.0360 \\
.0339 \\
.0350\end{array}$ & $\begin{array}{r}0.200 \\
.250 \\
.404 \\
.404 \\
.498 \\
.497 \\
.534 \\
.524 \\
.550 \\
.127 \\
.152 \\
.142 \\
.108\end{array}$ & $\begin{array}{r}0.320 \\
.358 \\
.455 \\
.455 \\
.505 \\
.505 \\
.523 \\
.518 \\
.531 \\
.254 \\
.278 \\
.269 \\
.234\end{array}$ & $\begin{array}{r}1.50 \\
1.39 \\
4.28 \\
2.23 \\
1.54 \\
3.95 \\
7.39 \\
1.90 \\
.92 \\
1.20 \\
1.09 \\
.99\end{array}$ & \begin{tabular}{c}
7.1 \\
18.0 \\
428 \\
244 \\
\hdashline 72 \\
187 \\
969 \\
54 \\
1.3 \\
3.0 \\
2.3 \\
9.4
\end{tabular} & $\begin{array}{r}0.00131 \\
.00177 \\
.00095 \\
.00184 \\
.00328 \\
.00138 \\
.00072 \\
.00295 \\
.00134 \\
.00126 \\
.00126 \\
.00105\end{array}$ & $\begin{array}{r}1.48 \\
1.49 \\
1.43 \\
1.49 \\
1.39 \\
1.48 \\
1.40 \\
1.42 \\
-1\end{array}$ \\
\hline
\end{tabular}


FLUVIAL CHARACTERISTICS AND HYDRAULIC VARIABLES F59

TABLE 9.-Basic data and computed parameters for the Rio Grande at Angostura heading near Algodones

[S, see column $26 ; d$, see column 25.]

\begin{tabular}{l|c|c|c|c|c|c|c|c|c}
\hline \multirow{2}{*}{ Run } & Date & 1 & 2 & 3 & 4 & 5 & 6 & 7 & 8 \\
\cline { 2 - 5 } & $Q$ & $Q / b$ & $\begin{array}{c}\text { Bed } \\
\text { elevation }\end{array}$ & $D$ & $b$ & $R$ & $\mathrm{~V}$ & $C_{m}$ \\
\hline
\end{tabular}

Rio Grande above Angostura heading

\begin{tabular}{|c|c|c|c|c|c|c|c|c|c|}
\hline $\begin{array}{l}1 \\
\mathbf{2} \\
\mathbf{3}\end{array}$ & $\begin{array}{l}5-4-54 \\
5-6-54 \\
5-8-54\end{array}$ & $\begin{array}{r}1,200 \\
946 \\
902\end{array}$ & $\begin{array}{l}5.4 \\
4.2 \\
4.0\end{array}$ & 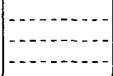 & $\begin{array}{l}2.00 \\
1.84 \\
1.77\end{array}$ & $\begin{array}{l}222 \\
224 \\
223\end{array}$ & $\begin{array}{l}1.96 \\
1.81 \\
1.74\end{array}$ & $\begin{array}{l}2.70 \\
2.29 \\
2.28\end{array}$ & $\begin{array}{r}1,800 \\
970 \\
788\end{array}$ \\
\hline
\end{tabular}

Settling basin at Angostura heading

\begin{tabular}{|c|c|c|c|c|c|c|c|c|c|}
\hline $\begin{array}{l}1 \\
\mathbf{1}^{2} \\
\mathbf{3} \\
\mathbf{4} \\
\mathbf{5}\end{array}$ & $\begin{array}{r}5-4-54 \\
5-6-54 \\
5-8-54 \\
1-11-56 \\
1-12-56\end{array}$ & $\begin{array}{l}588 \\
554 \\
541 \\
510 \\
527\end{array}$ & $\begin{array}{r}10.8 \\
10.1 \\
9.8 \\
9.7 \\
9.8\end{array}$ & 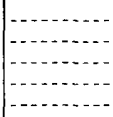 & $\begin{array}{l}3.45 \\
3.77 \\
3.62 \\
2.13 \\
2.04\end{array}$ & $\begin{array}{l}54.5 \\
54.7 \\
55.0 \\
52.5 \\
54.0\end{array}$ & $\begin{array}{l}3.06 \\
3.32 \\
2.30 \\
1.97 \\
2.00\end{array}$ & $\begin{array}{l}3.13 \\
2.69 \\
2.72 \\
4.55 \\
4.77\end{array}$ & $\begin{array}{r}1,960 \\
1,130 \\
874 \\
2,540 \\
2,550\end{array}$ \\
\hline
\end{tabular}

Albuquerque main canal at Angostura heading

\begin{tabular}{|c|c|c|c|c|c|c|c|c|c|}
\hline $\begin{array}{l}1 \\
1 \\
2 \\
3\end{array}$ & $\begin{array}{l}5-4-54 \\
5-6-54 \\
5-8-54\end{array}$ & $\begin{array}{l}391 \\
457 \\
394\end{array}$ & $\begin{array}{l}7.8 \\
9.1 \\
7.9\end{array}$ & 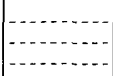 & $\begin{array}{l}3.48 \\
3.56 \\
2.96\end{array}$ & $\begin{array}{l}50 \\
50 \\
50\end{array}$ & $\begin{array}{l}3.05 \\
3.12 \\
2.65\end{array}$ & $\begin{array}{l}2.25 \\
2.57 \\
2.66\end{array}$ & $\begin{array}{r}1,940 \\
1,120 \\
922\end{array}$ \\
\hline
\end{tabular}

Wasteway at Angostura heading

\begin{tabular}{|c|c|c|c|c|c|c|c|c|c|}
\hline $\begin{array}{l}\mathbf{1} \\
\mathbf{2} \\
\mathbf{3}\end{array}$ & $\begin{array}{l}5-4-54 \\
5-6-54 \\
5-8-54\end{array}$ & $\begin{array}{r}197 \\
97 \\
147\end{array}$ & $\begin{array}{l}3.4 \\
1.8 \\
2.7\end{array}$ & $\mid \begin{array}{c}-\ldots \\
-\ldots \\
\cdots \\
-\cdots\end{array}$ & $\begin{array}{l}2.32 \\
1.58 \\
1.58\end{array}$ & $\begin{array}{l}58 \\
55 \\
54\end{array}$ & $\begin{array}{l}2.15 \\
1.49 \\
1.49\end{array}$ & $\begin{array}{l}1.46 \\
1.12 \\
1.72\end{array}$ & $\begin{array}{r}1,520 \\
750 \\
663\end{array}$ \\
\hline
\end{tabular}


TABLE 9.-Basic data and computed parameters for the Rio Grande at Angostura heading near Algodones-Continued

\begin{tabular}{c|c|c|c|c|c|c|c|c|c}
\hline \multirow{2}{*}{ Run } & 9 & 10 & 11 & 12 & 13 & 14 & 15 & 16 & 17 \\
\cline { 2 - 3 } & $C_{T}$ & $Q_{s}$ & $\frac{Q_{s}>0.062 \mathrm{~mm}}{b}$ & $\begin{array}{c}\text { Einstein } \\
Q_{\mathrm{I} / b}\end{array}$ & $\begin{array}{c}\text { Bagnold } \\
Q_{\mathrm{I}} / b\end{array}$ & Regime & $T$ & $\nu \times 10^{5}$ & $\omega$ \\
\hline
\end{tabular}

Rio Grande above Angostura heading-Continued

\begin{tabular}{|c|c|c|c|c|c|c|c|c|c|}
\hline $\begin{array}{l}\mathbf{1} \\
\mathbf{2} \\
\mathbf{3}\end{array}$ & $\begin{array}{l}504 \\
340 \\
260\end{array}$ & $\begin{array}{l}5,830 \\
2,480 \\
1,920\end{array}$ & $\begin{array}{l}7.3 \\
3.9 \\
2.8\end{array}$ & $\begin{array}{l}34 \\
16 \\
12\end{array}$ & $\begin{array}{l}30 \\
13 \\
10\end{array}$ & 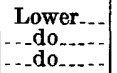 & $\begin{array}{l}17 \\
18 \\
18\end{array}$ & $\begin{array}{l}1.16 \\
1.13 \\
1.13\end{array}$ & $\begin{array}{r}0.182 \\
.183 \\
.183\end{array}$ \\
\hline
\end{tabular}

Settling basin at Angostura heading-Continued

\begin{tabular}{|c|c|c|c|c|c|c|c|c|c|}
\hline $\begin{array}{l}1 \\
2 \\
3 \\
4 \\
5\end{array}$ & $\begin{array}{r}588 \\
497 \\
411 \\
2,160 \\
2,040\end{array}$ & $\begin{array}{l}3,120 \\
1,690 \\
1,280 \\
3,500 \\
3,630\end{array}$ & $\begin{array}{l}17 \\
14 \\
11 \\
57 \\
54\end{array}$ & $\begin{array}{r}68 \\
44 \\
40 \\
107 \\
110\end{array}$ & $\begin{array}{l}66 \\
37 \\
28 \\
93 \\
92\end{array}$ & 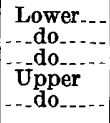 & $\begin{array}{r}18 \\
19 \\
19 \\
2 \\
6\end{array}$ & $\begin{array}{l}1.13 \\
1.10 \\
1.10 \\
1.81 \\
1.63\end{array}$ & $\begin{array}{r}0.170 \\
.171 \\
.171 \\
.131 \\
.141\end{array}$ \\
\hline
\end{tabular}

Albuquerque main canal at Angostura heading-Continued

\begin{tabular}{|c|c|c|c|c|c|c|c|c|c|}
\hline $\begin{array}{l}1 \\
1 \\
2 \\
3\end{array}$ & $\begin{array}{l}582 \\
526 \\
378\end{array}$ & $\begin{array}{r}2,050 \\
1,380 \\
981\end{array}$ & $\begin{array}{l}12 \\
13 \\
8.2\end{array}$ & $\begin{array}{l}48 \\
34 \\
26\end{array}$ & $\begin{array}{l}46 \\
34 \\
24\end{array}$ & $\begin{array}{c}\text { Lower... } \\
\text { do do....... }\end{array}$ & $\begin{array}{l}17 \\
18 \\
18\end{array}$ & $\begin{array}{l}1.16 \\
1.13 \\
1.13\end{array}$ & $\begin{array}{r}0.120 \\
.121 \\
.121\end{array}$ \\
\hline
\end{tabular}

Wasteway at Angostura heading-Continued

\begin{tabular}{|c|c|c|c|c|c|c|c|c|c|}
\hline $\begin{array}{l}\mathbf{1} \\
\mathbf{2} \\
\mathbf{3}\end{array}$ & $\begin{array}{l}380 \\
225 \\
225\end{array}$ & $\begin{array}{l}808 \\
196 \\
263\end{array}$ & $\begin{array}{l}3.5 \\
1.1 \\
1.7\end{array}$ & $\begin{array}{r}17 \\
4.2 \\
7.4\end{array}$ & $\begin{array}{l}16 \\
4.1 \\
5.7\end{array}$ & $\begin{array}{c}\text { Lower... } \\
- \text { do do } \\
- \text { do }\end{array}$ & $\begin{array}{l}18 \\
17 \\
16\end{array}$ & $\begin{array}{l}1.13 \\
1.16 \\
1.20\end{array}$ & $\begin{array}{r}0.178 \\
.178 \\
.177\end{array}$ \\
\hline
\end{tabular}


FLUVIal CharaCteristics aNd HYdRaulic variables F'61

TABLE 9.-Basic data and computed parameters for the Rio Grande at Angostura heading near Algodones-Continued

\begin{tabular}{l|c|c|c|c|c|c|c|c|c|c}
\hline \multirow{2}{*}{ Run } & 18 & 19 & 20 & 21 & 22 & 23 & 24 & 25 & 26 & 27 \\
\cline { 2 - 4 } & $\mathrm{F}$ & $C / \sqrt{g}$ & $n$ & $r_{0}$ & $V_{*}$ & $\theta$ & $\phi$ & $d$ & $\mathrm{~S}$ & $1+\frac{B_{b}}{B_{a}}$ \\
\hline
\end{tabular}

Rio Grande above Angostura heading-Continued

\begin{tabular}{|c|c|c|c|c|c|c|c|c|c|c|}
\hline $\begin{array}{l}\mathbf{1} \\
\mathbf{2} \\
\mathbf{3}\end{array}$ & $\begin{array}{r}0.34 \\
.30 \\
.30\end{array}$ & $\begin{array}{l}9.5 \\
8.4 \\
8.5\end{array}$ & $\begin{array}{r}0.0295 \\
.0329 \\
.0322\end{array}$ & $\begin{array}{r}0.160 \\
.147 \\
.142\end{array}$ & $\begin{array}{r}0.284 \\
.273 \\
.268\end{array}$ & $\begin{array}{r}1.06 \\
.98 \\
.94\end{array}$ & $\begin{array}{l}8.9 \\
4.6 \\
3.4\end{array}$ & $\begin{array}{r}0.00128 \\
.00128 \\
.00128\end{array}$ & $\begin{array}{r}0.00112 \\
.00112 \\
.00112\end{array}$ & $\begin{array}{l}1.47 \\
1.47 \\
1.47\end{array}$ \\
\hline
\end{tabular}

Settling basin at Angostura heading-Continued

\begin{tabular}{|c|c|c|c|c|c|c|c|c|c|c|}
\hline $\begin{array}{l}\mathbf{1} \\
\mathbf{2} \\
\mathbf{3} \\
\mathbf{4} \\
\mathbf{5}\end{array}$ & $\begin{array}{r}0.30 \\
.24 \\
.25 \\
.55 \\
.59\end{array}$ & $\begin{array}{r}9.2 \\
7.6 \\
8.0 \\
16.6 \\
17.3\end{array}$ & $\begin{array}{r}0.0178 \\
.0221 \\
.0212 \\
.0089 \\
.0083\end{array}$ & $\begin{array}{r}0.129 \\
.141 \\
.136 \\
.080 \\
.077\end{array}$ & $\begin{array}{r}0.341 \\
.355 \\
.349 \\
.274 \\
.276\end{array}$ & $\begin{array}{r}1.06 \\
1.16 \\
1.11 \\
.66 \\
.63\end{array}$ & $\begin{array}{l}2.5 \\
2.0 \\
1.6 \\
8.2 \\
7.8\end{array}$ & $\begin{array}{r}0.0006 \\
.0006 \\
.0006 \\
.0006 \\
.0006\end{array}$ & $\begin{array}{r}0.00118 \\
.00118 \\
.00118 \\
.00118 \\
.00118\end{array}$ & $\begin{array}{l}1.46 \\
1.46 \\
1.46 \\
1.46 \\
1.46\end{array}$ \\
\hline
\end{tabular}

Albuquerque main canal at Angostura heading-Continued

\begin{tabular}{|c|c|c|c|c|c|c|c|c|c|c|}
\hline $\begin{array}{l}1 \\
2 \\
3\end{array}$ & $\begin{array}{r}0.21 \\
.24 \\
.27\end{array}$ & $\begin{array}{l}7.5 \\
8.4 \\
9.5\end{array}$ & $\begin{array}{r}0.0250 \\
.0222 \\
.0190\end{array}$ & $\begin{array}{r}0.131 \\
.134 \\
.111\end{array}$ & $\begin{array}{r}0.300 \\
.304 \\
.280\end{array}$ & $\begin{array}{l}1.38 \\
1.41 \\
1.17\end{array}$ & $\begin{array}{l}3.3 \\
3.4 \\
2.2\end{array}$ & $\begin{array}{r}0.0006 \\
.0006 \\
.0006\end{array}$ & $\begin{array}{r}0.00092 \\
.00092 \\
.00092\end{array}$ & $\begin{array}{l}1.43 \\
1.43 \\
1.43\end{array}$ \\
\hline
\end{tabular}

Wasteway at Angostura heading-Continued

\begin{tabular}{|c|c|c|c|c|c|c|c|c|c|c|}
\hline $\begin{array}{l}1 \\
2 \\
3\end{array}$ & $\begin{array}{r}0.17 \\
.16 \\
.24\end{array}$ & $\begin{array}{l}4.9 \\
4.6 \\
7.0\end{array}$ & $\begin{array}{r}0.0294 \\
.0296 \\
.0193\end{array}$ & $\begin{array}{r}0.087 \\
.059 \\
.059\end{array}$ & $\begin{array}{r}0.295 \\
.245 \\
.245\end{array}$ & $\begin{array}{r}0.68 \\
.46 \\
.46\end{array}$ & $\begin{array}{l}4.5 \\
1.4 \\
2.1\end{array}$ & $\begin{array}{r}0.0006 \\
.0006 \\
.0006\end{array}$ & $\begin{array}{r}0.00125 \\
.00125 \\
.00125\end{array}$ & $\begin{array}{l}1.47 \\
1.47 \\
1.47\end{array}$ \\
\hline
\end{tabular}


TABLE 10.-Basic data and computed parameters for the Rio Grande near Bernalillo, section A-2

$\left[S=0.00095 \mathrm{ft}\right.$ per ft; $\left.d=0.00098 \mathrm{ft}, 0.30 \mathrm{~mm} ;\left(1+\frac{B_{b}}{B_{s}}\right)=1.46\right]$

\begin{tabular}{|c|c|c|c|c|c|c|c|c|c|}
\hline \multirow[b]{2}{*}{ Run } & \multirow[b]{2}{*}{ Date } & 1 & 2 & 3 & 4 & 5 & 6 & 7 & 8 \\
\hline & & $O$ & $Q / b$ & $\begin{array}{c}\text { Bed } \\
\text { elevation }\end{array}$ & $D$ & $b$ & $R$ & $\boldsymbol{V}$ & $C_{m}$ \\
\hline $\begin{array}{l}6 \\
15 \\
15 \\
4\end{array}$ & $\begin{array}{r}7-24-52 \\
6-2-53 \\
4-25-52 \\
6-26-52 \\
6-18-58 \\
6-13-58 \\
6-20-52 \\
6-10-58 \\
6-25-58 \\
6-17-52 \\
5-12-52 \\
5-8-58 \\
6-4-58 \\
5-13-58 \\
5-21-58 \\
5-27-58 \\
4-29-53 \\
5-5-53 \\
6-1-53 \\
6-4-53 \\
6-17-53\end{array}$ & $\begin{array}{r}2,060 \\
2,150 \\
2,730 \\
2,760 \\
4,000 \\
4,340 \\
4,830 \\
5,800 \\
6,040 \\
6,140 \\
6,490 \\
6,860 \\
8,160 \\
8,320 \\
8,680 \\
10,100 \\
1,540 \\
550 \\
2,570 \\
2,090 \\
1,340\end{array}$ & $\begin{array}{r}7.6 \\
8.0 \\
10.0 \\
10.3 \\
15.0 \\
16.3 \\
17.8 \\
21.5 \\
22.1 \\
22.6 \\
23.9 \\
25.4 \\
30.0 \\
30.7 \\
32.1 \\
37.0 \\
5.7 \\
2.1 \\
9.5 \\
7.7 \\
5.0\end{array}$ & $\begin{array}{l}2.49 \\
2.89 \\
3.07 \\
2.22 \\
1.96 \\
2.31 \\
1.81 \\
1.86 \\
2.12 \\
2.12 \\
2.22 \\
2.27 \\
1.64 \\
1.78 \\
2.21 \\
1.73 \\
2.19 \\
3.07 \\
2.74 \\
2.74 \\
2.75\end{array}$ & $\begin{array}{l}2.69 \\
2.56 \\
2.47 \\
2.76 \\
2.96 \\
2.67 \\
3.49 \\
3.43 \\
3.40 \\
3.79 \\
3.63 \\
3.68 \\
4.34 \\
4.46 \\
4.11 \\
4.80 \\
2.15 \\
1.25 \\
2.66 \\
2.48 \\
2.14\end{array}$ & $\begin{array}{l}270 \\
270 \\
272 \\
269 \\
267 \\
266 \\
272 \\
270 \\
273 \\
272 \\
272 \\
270 \\
272 \\
271 \\
270 \\
273 \\
270 \\
265 \\
270 \\
270 \\
268\end{array}$ & $\begin{array}{l}2.64 \\
2.51 \\
2.43 \\
2.70 \\
2.90 \\
2.62 \\
3.40 \\
3.35 \\
3.32 \\
3.69 \\
3.54 \\
3.58 \\
4.21 \\
4.32 \\
3.98 \\
4.64 \\
2.12 \\
1.24 \\
2.61 \\
2.44 \\
2.11\end{array}$ & $\begin{array}{l}2.84 \\
3.11 \\
4.06 \\
3.71 \\
5.06 \\
6.10 \\
5.09 \\
6.27 \\
6.50 \\
5.96 \\
6.57 \\
6.91 \\
6.92 \\
6.88 \\
7.82 \\
7.71 \\
2.65 \\
1.66 \\
3.58 \\
3.12 \\
2.34\end{array}$ & $\begin{array}{r}2,490 \\
2,010 \\
3,320 \\
1,040 \\
5,980 \\
2,080 \\
1,690 \\
3,480 \\
5,410 \\
1,990 \\
3,160 \\
4,420 \\
2,580 \\
4,740 \\
3,400 \\
3,040 \\
2,450 \\
545 \\
2,530 \\
1,600 \\
1,050\end{array}$ \\
\hline
\end{tabular}

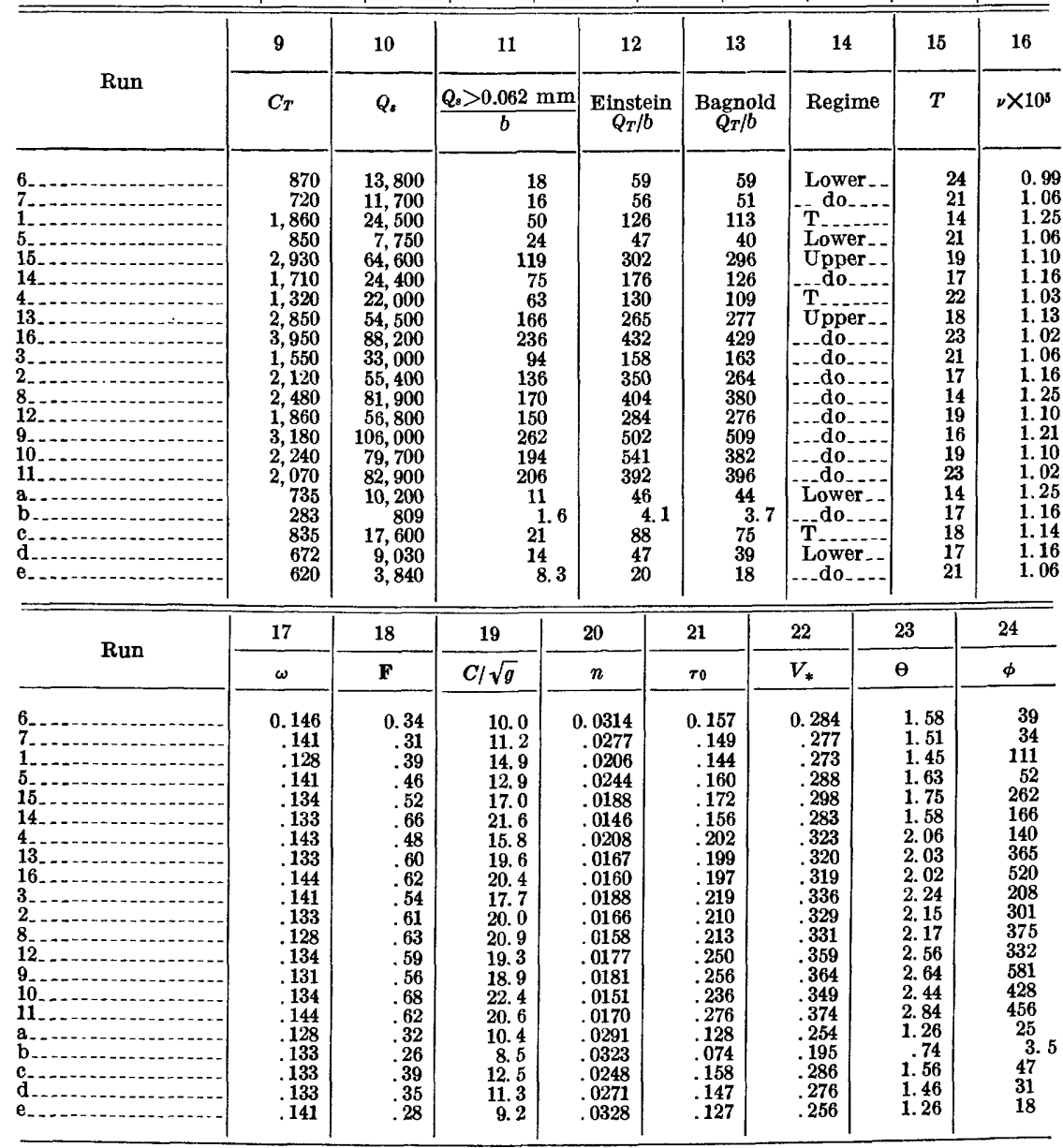


FLUVIAL CHARACTERISTICS AND HYDRAULIC VARIABLES F63

TABLE 11.-Basic data and computed parameters for the Rio Grande near Bernalillo, sections A, B, C, D, E

$\left[\left[S\right.\right.$, see column $\left.25 ; d=0.00098,0.30 \mathrm{~mm} ;\left(1+\frac{B_{b}}{B_{s}}\right)=1.46\right]$

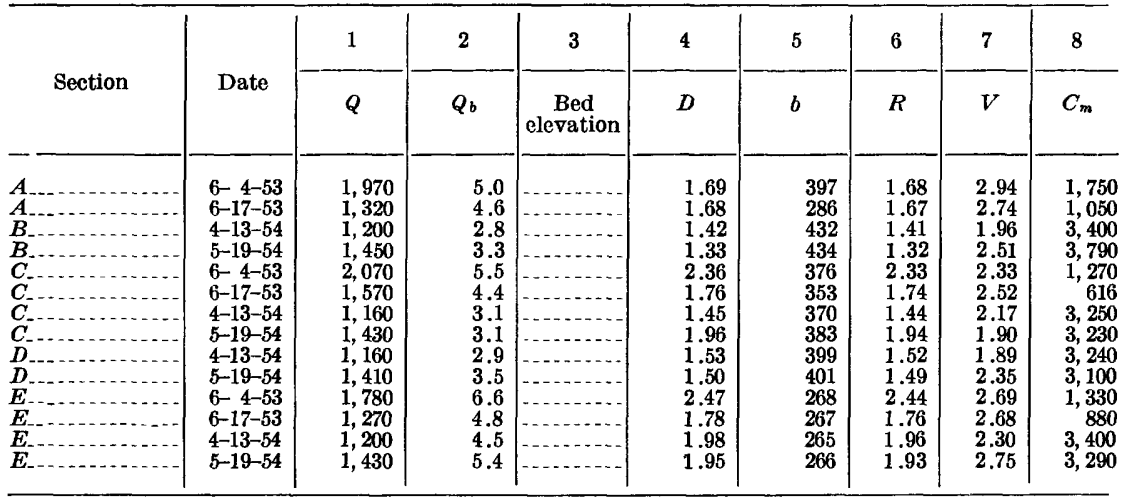

\begin{tabular}{|c|c|c|c|c|c|c|c|c|c|}
\hline \multirow{2}{*}{ Section } & 9 & 10 & 11 & 12 & 13 & 14 & 15 & 16 & 17 \\
\hline & $C T$ & $Q_{s}$ & $\frac{Q_{s}>0.062 \mathrm{~mm}}{b}$ & $\begin{array}{c}\text { Einstein } \\
Q_{\boldsymbol{r}} / b\end{array}$ & $\begin{array}{c}\text { Bagnold } \\
Q_{\boldsymbol{r}} / b\end{array}$ & Regime & $T$ & $\nu \times 10^{5}$ & $\omega$ \\
\hline $\begin{array}{l}A \\
A \\
B \\
B \\
C \\
C \\
C \\
C\end{array}$ & $\begin{array}{l}892 \\
682 \\
442 \\
834 \\
444 \\
203 \\
520 \\
711 \\
389 \\
620 \\
692 \\
370 \\
544 \\
559\end{array}$ & $\begin{array}{r}9,290 \\
3,740 \\
11,020 \\
14,800 \\
7,100 \\
2,610 \\
10,200 \\
12,500 \\
10,100 \\
11,800 \\
6,410 \\
3,030 \\
11,000 \\
12,700\end{array}$ & $\begin{array}{r}11.9 \\
8.5 \\
3.3 \\
7.5 \\
6.6 \\
2.4 \\
4.4 \\
7.2 \\
3.0 \\
5.9 \\
12.4 \\
4.8 \\
6.7 \\
8.1\end{array}$ & $\begin{array}{l}35 \\
19 \\
28 \\
42 \\
25 \\
13 \\
32 \\
35 \\
28 \\
35 \\
33 \\
18 \\
47 \\
56\end{array}$ & $\begin{array}{l}28 \\
17 \\
28 \\
36 \\
22 \\
8.5 \\
30 \\
36 \\
26 \\
32 \\
30 \\
14 \\
45 \\
52\end{array}$ & 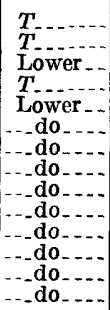 & $\begin{array}{l}19 \\
24 \\
17 \\
20 \\
22 \\
24 \\
17 \\
23 \\
17 \\
23 \\
21 \\
23 \\
17 \\
21\end{array}$ & $\begin{array}{l}1.10 \\
.99 \\
1.16 \\
1.09 \\
1.03 \\
.99 \\
1.16 \\
1.02 \\
1.16 \\
1.02 \\
1.06 \\
1.02 \\
1.16 \\
1.06\end{array}$ & $\begin{array}{r}0.134 \\
.146 \\
.133 \\
.134 \\
.143 \\
.146 \\
.133 \\
.144 \\
.133 \\
.144 \\
.141 \\
.144 \\
.133 \\
.141\end{array}$ \\
\hline
\end{tabular}

\begin{tabular}{|c|c|c|c|c|c|c|c|c|}
\hline \multirow{2}{*}{ Section } & 18 & 19 & 20 & 21 & 22 & 23 & 24 & 25 \\
\hline & $\mathbf{F}$ & $C / \sqrt{g}$ & $n$ & $\tau_{0}$ & $V_{*}$ & $\boldsymbol{\theta}$ & $\phi$ & $S$ \\
\hline 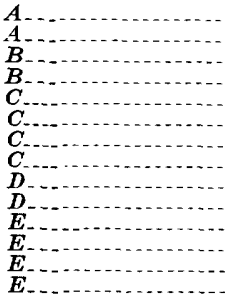 & $\begin{array}{r}0.40 \\
.37 \\
.29 \\
.38 \\
.27 \\
.33 \\
.32 \\
.24 \\
.27 \\
.34 \\
.30 \\
.35 \\
.29 \\
.35\end{array}$ & $\begin{array}{r}13.0 \\
12.1 \\
9.4 \\
12.5 \\
10.1 \\
12.7 \\
12.0 \\
9.0 \\
10.2 \\
12.8 \\
11.4 \\
13.3 \\
10.9 \\
13.1\end{array}$ & $\begin{array}{l}0.0222 \\
.0238 \\
.0297 \\
.0223 \\
.0305 \\
.0232 \\
.0237 \\
.0331 \\
.0282 \\
.0224 \\
.0273 \\
.0220 \\
.0276 \\
.0228\end{array}$ & $\begin{array}{l}0.100 \\
.100 \\
.084 \\
.079 \\
.106 \\
.079 \\
.065 \\
.088 \\
.069 \\
.068 \\
.111 \\
.080 \\
.089 \\
.088\end{array}$ & $\begin{array}{l}0.227 \\
.226 \\
.208 \\
.201 \\
.231 \\
.199 \\
.181 \\
.210 \\
.186 \\
.184 \\
.236 \\
.201 \\
.211 \\
.210\end{array}$ & $\begin{array}{r}1.00 \\
.99 \\
.84 \\
.78 \\
1.39 \\
1.03 \\
.86 \\
1.15 \\
.90 \\
.88 \\
1.45 \\
1.05 \\
1.17 \\
1.15\end{array}$ & $\begin{array}{r}26.5 \\
18.7 \\
7.4 \\
16.4 \\
14.5 \\
5.3 \\
10.0 \\
15.7 \\
6.7 \\
12.9 \\
27.2 \\
10.6 \\
14.6 \\
18.0\end{array}$ & $\begin{array}{r}0.00095 \\
0.00095 \\
0.00095 \\
0.00095 \\
.00072 \\
.00072 \\
.00072 \\
.00072 \\
.00072 \\
.00072 \\
.00072 \\
.00072 \\
.00072 \\
.00072\end{array}$ \\
\hline
\end{tabular}


TABLE 12.-Basic data and computed parameters for the Rio Grande near Bernalillo, section $\mathrm{F}$

$\left[\mathrm{S}=0.00095 \mathrm{ft}\right.$ per ft; $\left.d=0.00098 \mathrm{ft}, 0.30 \mathrm{~m} ;\left(1+\frac{B_{b}}{B_{\mathrm{z}}}\right)=1.46\right]$

\begin{tabular}{|c|c|c|c|c|c|c|c|c|}
\hline \multirow{2}{*}{ Run } & \multirow{2}{*}{ Date } & 1 & 2 & 3 & 4 & 6 & 7 & 8 \\
\hline & & 0 & $Q / b$ & $\underset{\text { elevation }}{\text { Bed }}$ & $D$ & $\boldsymbol{R}$ & $\boldsymbol{V}$ & $C_{m}$ \\
\hline $\begin{array}{l}7 \\
5 \\
1 \\
14 \\
4 \\
15 \\
13- \\
16 \\
3 \\
2 \\
8 \\
12 \\
12 \\
9 \\
10 \\
11\end{array}$ & $\begin{array}{l}7-24-52 \\
6-2-53 \\
6-26-52 \\
4-25-52 \\
6-13-58 \\
6-20-52 \\
6-18-58 \\
6-10-58 \\
6-25-58 \\
6-17-52 \\
5-12-52 \\
5-8-58 \\
6-4-58 \\
5-13-58 \\
5-21-58 \\
5-27-58\end{array}$ & $\begin{array}{l}2,030 \\
2,400 \\
2,850 \\
2,910 \\
4,380 \\
4,720 \\
4,730 \\
5,440 \\
5,960 \\
6,100 \\
6,390 \\
6,730 \\
7,790 \\
8,310 \\
8,700 \\
9,970\end{array}$ & $\begin{array}{r}3.5 \\
3.7 \\
7.7 \\
4.5 \\
8.8 \\
13.5 \\
9.1 \\
10.5 \\
11.2 \\
12.5 \\
11.2 \\
12.1 \\
15.3 \\
15.4 \\
13.5 \\
15.7\end{array}$ & \begin{tabular}{l}
$-\cdot-\cdot-$ \\
\hdashline..-- \\
\hdashline 3.59 \\
-3.12 \\
3.87 \\
3.61 \\
\hdashline-1. \\
4.05 \\
3.28 \\
3.85 \\
4.51 \\
4.26
\end{tabular} & $\begin{array}{l}1.58 \\
1.37 \\
2.41 \\
1.18 \\
1.91 \\
2.45 \\
2.28 \\
2.13 \\
2.09 \\
2.18 \\
2.07 \\
2.15 \\
2.72 \\
2.55 \\
2.19 \\
2.64\end{array}$ & $\begin{array}{l}1.58 \\
1.36 \\
2.38 \\
1.18 \\
1.90 \\
2.42 \\
2.26 \\
2.11 \\
2.07 \\
2.16 \\
2.06 \\
2.13 \\
2.69 \\
2.53 \\
2.18 \\
2.62\end{array}$ & $\begin{array}{l}2.20 \\
2.71 \\
3.20 \\
3.86 \\
4.60 \\
5.50 \\
4.01 \\
4.91 \\
5.36 \\
5.73 \\
5.42 \\
5.61 \\
5.64 \\
6.02 \\
6.17 \\
5.93\end{array}$ & $\begin{array}{l}1,740 \\
1,900 \\
852 \\
2,820 \\
1,990 \\
1,460 \\
5,420 \\
2,070 \\
2,800 \\
1,500 \\
2,690 \\
4,700 \\
2,500 \\
4,220 \\
3,350 \\
3,060\end{array}$ \\
\hline \multirow{2}{*}{ Run } & 9 & 10 & 11 & 12 & 13 & 14 & 15 & 16 \\
\hline & $C_{T}$ & $Q_{s}$ & $\frac{Q_{s}>0.062 \mathrm{~mm}}{b}$ & $\underset{Q_{\pi} / b}{\text { Einstein }}$ & $\begin{array}{c}\text { Bagnold } \\
Q r / b\end{array}$ & Regime & $T$ & $\nu \times 10^{5}$ \\
\hline 10 & $\begin{array}{r}574 \\
494 \\
630 \\
1,550 \\
1,670 \\
1,140 \\
3,250 \\
1,450 \\
1,260 \\
1,120 \\
1,530 \\
2,680 \\
1,750 \\
2,570 \\
2,140 \\
2,020\end{array}$ & $\begin{array}{r}9,540 \\
12,300 \\
6,560 \\
22,200 \\
23,500 \\
18,600 \\
69,200 \\
30,500 \\
45,100 \\
24,700 \\
46,400 \\
85,400 \\
52,600 \\
94,700 \\
78,700 \\
82,400\end{array}$ & & $\begin{array}{r}5 \\
5 \\
13 \\
19 \\
40 \\
41 \\
80 \\
41 \\
38 \\
38 \\
46 \\
87 \\
72 \\
107 \\
78 \\
85\end{array}$ & $\begin{array}{l}21 \\
26 \\
28 \\
51 \\
17 \\
95\end{array}$ & 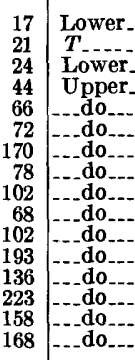 & $\begin{array}{l}27 \\
21 \\
21 \\
18 \\
19 \\
23 \\
22 \\
21 \\
25 \\
23 \\
18 \\
16 \\
22 \\
17 \\
20 \\
20\end{array}$ & $\begin{array}{l}0.93 \\
1.06 \\
1.06 \\
1.14 \\
1.11 \\
1.02 \\
1.04 \\
1.06 \\
.96 \\
1.02 \\
1.14 \\
1.20 \\
1.04 \\
1.16 \\
1.09 \\
1.09\end{array}$ \\
\hline \multirow{2}{*}{ Run } & 17 & 18 & 19 & 20 & 21 & 22 & 23 & 24 \\
\hline & $\omega$ & F & $C / \sqrt{g}$ & $n$ & $\tau_{0}$ & $V_{*}$ & $\theta$ & $\phi$ \\
\hline 0 & $\begin{array}{r}0.149 \\
.141 \\
.141 \\
.133 \\
.134 \\
.144 \\
.143 \\
.141 \\
.148 \\
.144 \\
.133 \\
.131 \\
.143 \\
.133 \\
.134 \\
.134\end{array}$ & $\begin{array}{l}0.31 \\
.41 \\
.36 \\
.63 \\
.59 \\
.62 \\
.47 \\
.59 \\
.66 \\
.68 \\
.66 \\
.67 \\
.60 \\
.66 \\
.73 \\
.64\end{array}$ & $\begin{array}{l}10.0 \\
13.3 \\
11.8 \\
17.6 \\
19.0 \\
20.2 \\
15.2 \\
19.3 \\
21.3 \\
22.2 \\
21.5 \\
22.0 \\
19.7 \\
21.6 \\
23.8 \\
21.0\end{array}$ & $\begin{array}{l}0.0284 \\
.0210 \\
.0260 \\
.0134 \\
.0154 \\
.0153 \\
.0199 \\
.0155 \\
.0141 \\
.0135 \\
.0138 \\
.0137 \\
.0159 \\
.0143 \\
.0126 \\
.0148\end{array}$ & $\begin{array}{l}0.094 \\
.081 \\
.143 \\
.070 \\
.113 \\
.145 \\
.135 \\
.126 \\
.124 \\
.129 \\
.123 \\
.128 \\
.162 \\
.151 \\
.130 \\
.157\end{array}$ & $\begin{array}{l}0.220 \\
.204 \\
.270 \\
.191 \\
.241 \\
.272 \\
.263 \\
.254 \\
.252 \\
.258 \\
.252 \\
.255 \\
.287 \\
.279 \\
.259 \\
.283\end{array}$ & $\begin{array}{l}0.93 \\
.81 \\
1.42 \\
.70 \\
1.12 \\
1.44 \\
1.35 \\
1.25 \\
1.28 \\
1.22 \\
1.27 \\
1.60 \\
1.50 \\
1.29 \\
1.55\end{array}$ & $\begin{array}{r}21 \\
25 \\
25 \\
50 \\
73 \\
82 \\
246 \\
77 \\
84 \\
29 \\
59 \\
250 \\
177 \\
289 \\
153 \\
157\end{array}$ \\
\hline
\end{tabular}


FLUVIAL CHARACTERISTICS AND HYDRAULIC VARIABLES F65

TABLE 13.-Basic data and computed parameters for the Rio Grande near Bernalillo, section A-Q-runoff from tributary inflow

$\left[S=0.00095 \mathrm{ft}\right.$ per $\left.\mathrm{ft} ; \mathrm{d}=0.00098 \mathrm{ft}, 0.30 \mathrm{~mm} ;\left(1+\frac{B_{b}}{B_{s}}\right)=1.46\right]$

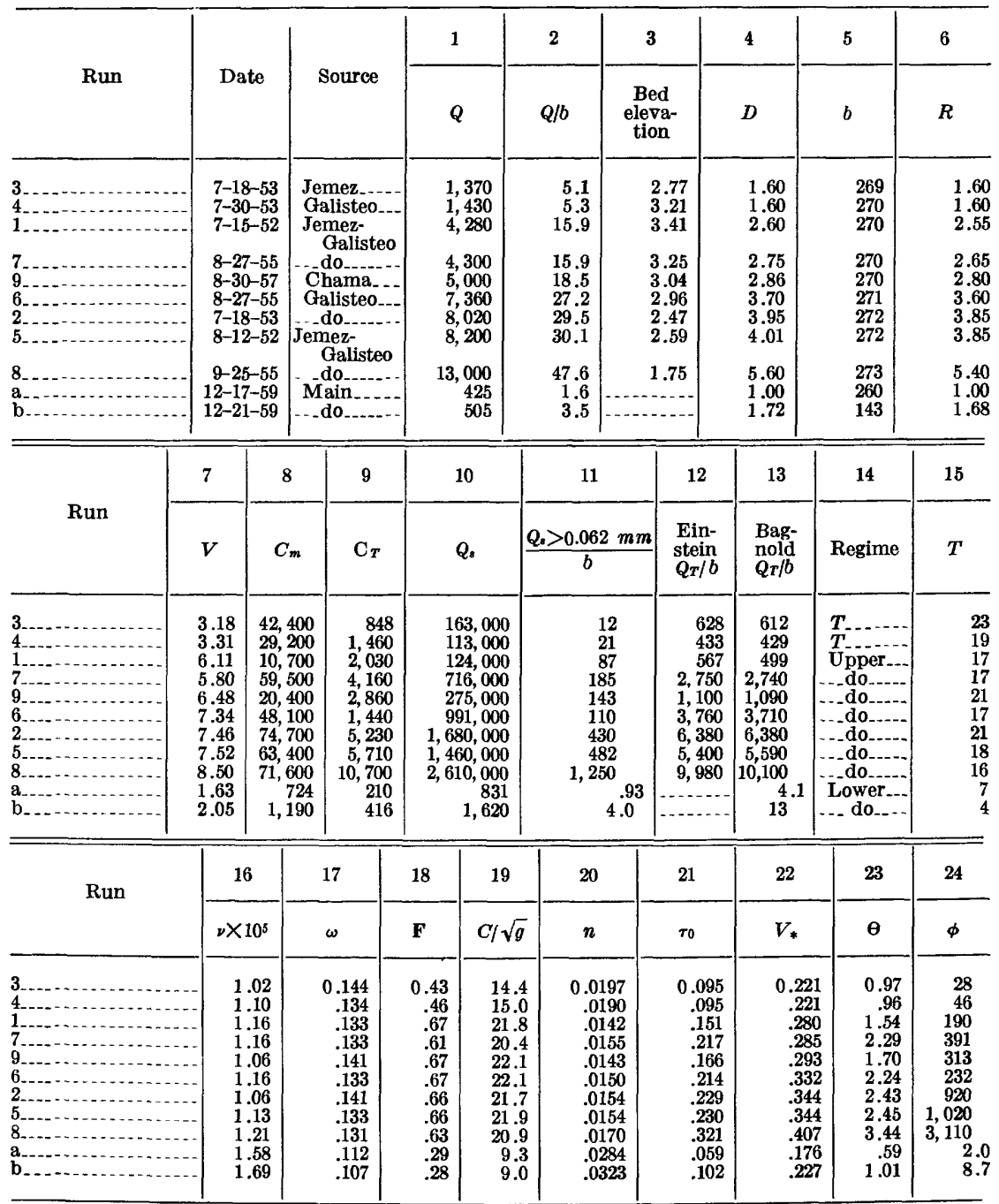




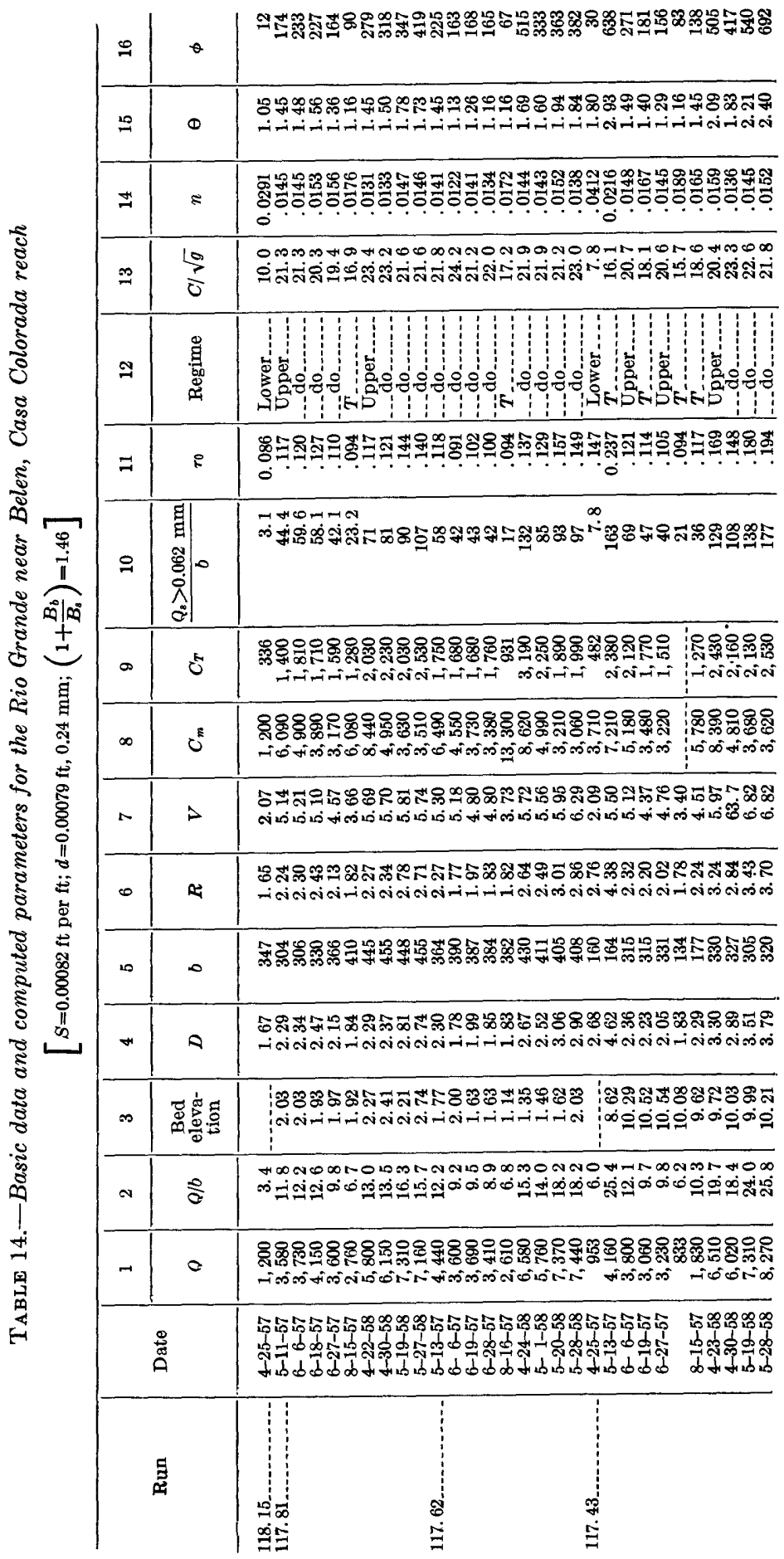




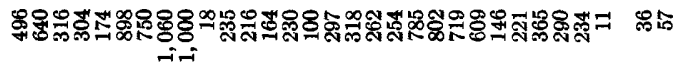

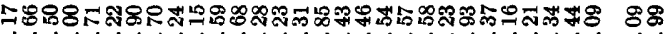

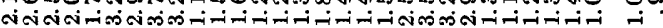

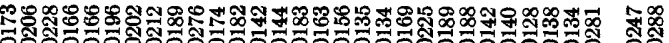

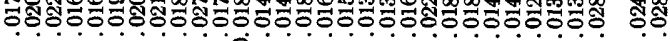

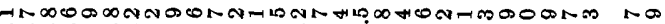

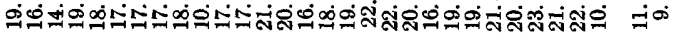

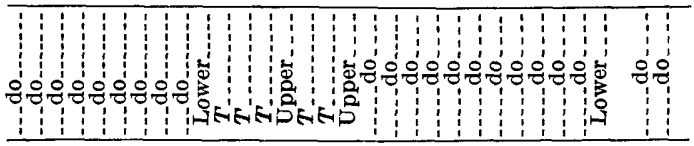

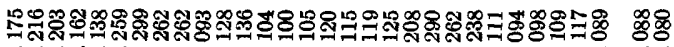
.....

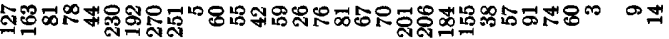

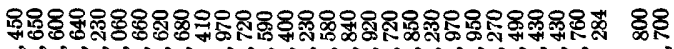

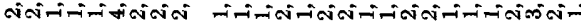

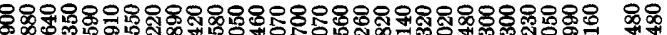

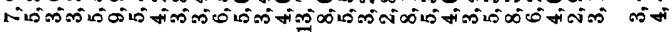

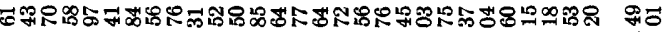

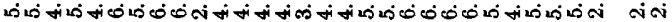

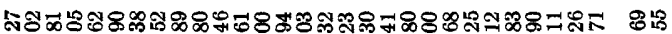

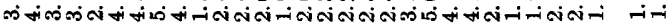

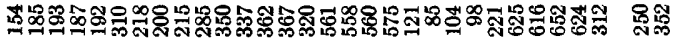

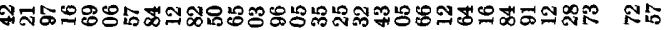

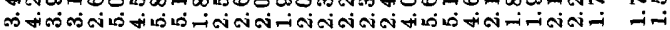

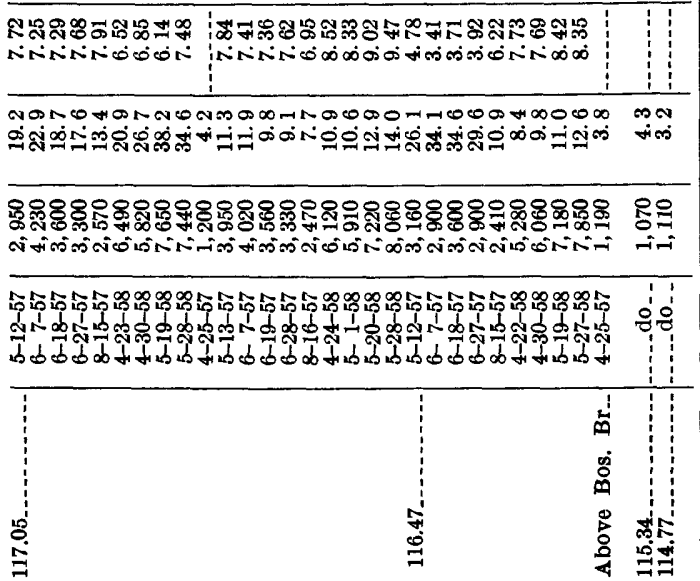




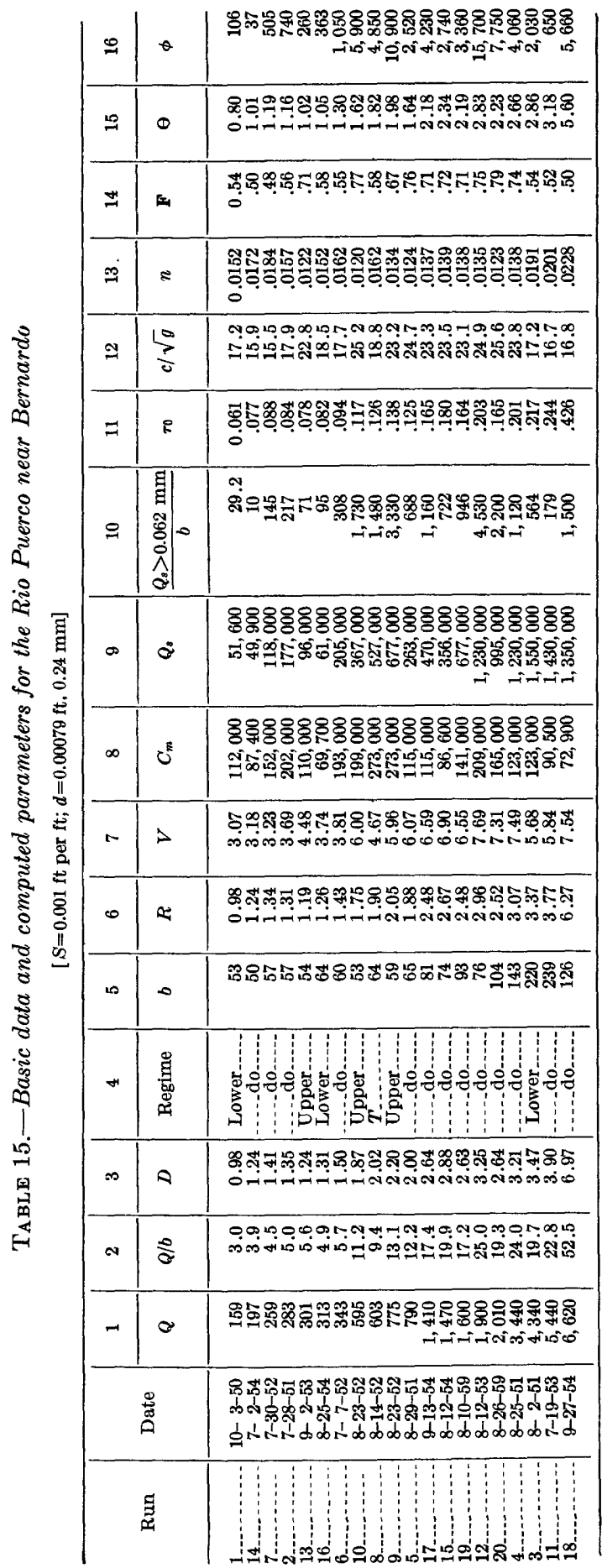


FLUVIAL CHARACTERISTICS AND HYDRAULIC VARIABLES F69

TABLE 16.-Basic data and computed parameters for the Rio Grande near Socorro reach

$\left[S=0.00075 \mathrm{ft}\right.$ per ft; $\left.d=0.00059 \mathrm{ft}, 0.18 \mathrm{~mm} ;\left(1+\frac{B_{b}}{B_{s}}\right)=1.38\right]$

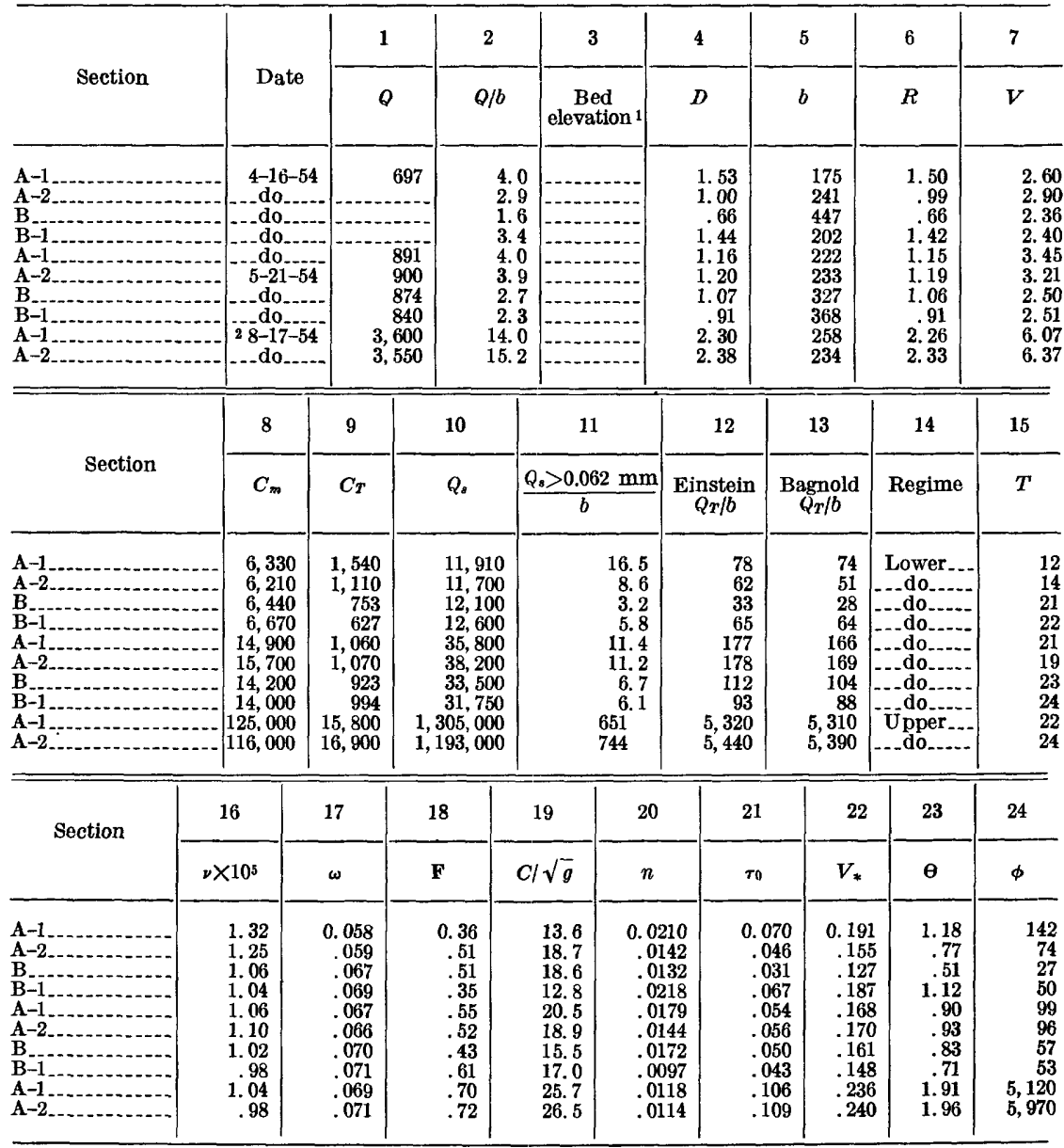

1 Not available.

1 Runs on Aug. 17, 1954, are Rio Puerco flow. 
TABLE 17.-Basic data and computed parameters for the Rio Grande at San Antonio

$\left[S=0.00055 \mathrm{ft}\right.$ per ft; $\left.d=0.00066 \mathrm{ft}, 0.20 \mathrm{~mm} ;\left(1+\frac{B_{b}}{\bar{B}_{s}}\right)=1.39\right]$

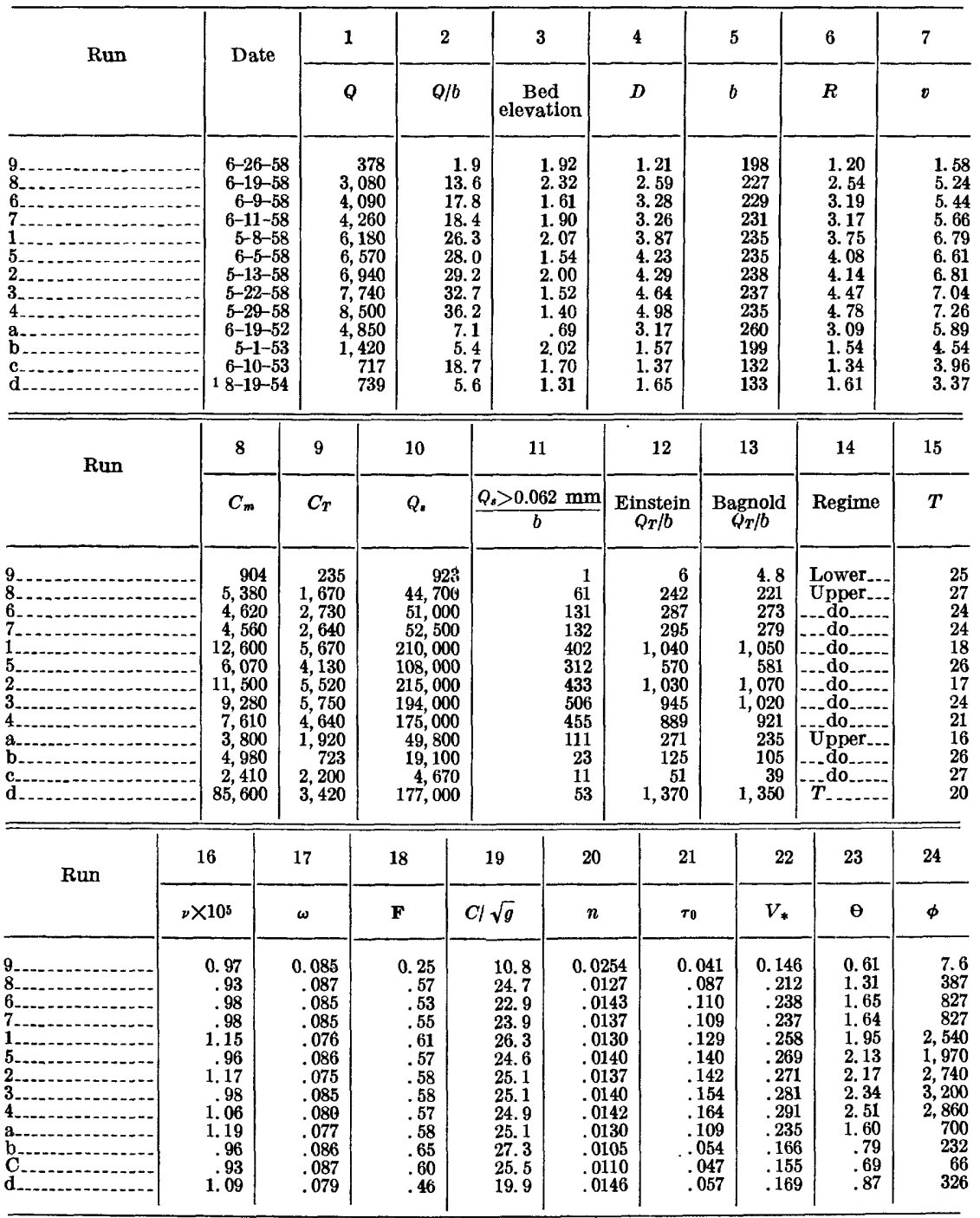

1 Run on Aug. 19, 1954, is Rio Puerco flow. 
FLUVIAL CHARACTERISTICS AND HYDRAULIC VARIABLES F71

TABLE 18.-Basic data and computed parameters for the Rio Grande Floodway at San Marcial

$\left[S=0.00041 \mathrm{ft}\right.$ per ft; $\left.d=0.00046 \mathrm{ft}, 0.14 \mathrm{~mm} ;\left(1+\frac{B_{b}}{B_{s}}\right)=1.36\right]$

\begin{tabular}{|c|c|c|c|c|c|c|c|c|}
\hline \multirow{2}{*}{ Run } & \multirow{2}{*}{ Date } & 1 & 2 & 3 & 4 & 5 & 6 & 7 \\
\hline & & $Q$ & $Q / b$ & $\begin{array}{c}\text { Bed } \\
\text { elevation }\end{array}$ & $D$ & $b$ & $R$ & $V$ \\
\hline $\begin{array}{l}9 \\
8 \\
6 \\
7 \\
1 \\
2 \\
5\end{array}$ & $\begin{array}{l}6-27-58 \\
6-20-58 \\
6-10-58 \\
6-12-58 \\
5-8-58 \\
5-12-58 \\
6-6-58 \\
5-22-58 \\
5-28-58\end{array}$ & $\begin{array}{l}1,990 \\
3,810 \\
4,230 \\
4,570 \\
6,170 \\
6,420 \\
6,870 \\
7,710 \\
8,680\end{array}$ & $\begin{array}{l}10.9 \\
20.3 \\
22.7 \\
24.2 \\
32.0 \\
33.3 \\
35.6 \\
40.4 \\
44.1\end{array}$ & $\begin{array}{r}9.69 \\
10.29 \\
9.18 \\
9,59 \\
10.00 \\
10.40 \\
9.24 \\
9.29 \\
9.04\end{array}$ & $\begin{array}{l}\text { 2. } 73 \\
\text { 3. } 62 \\
4.07 \\
4.06 \\
\text { 4. } 97 \\
5.03 \\
5.39 \\
6.23 \\
6.75\end{array}$ & $\begin{array}{l}183 \\
188 \\
186 \\
189 \\
193 \\
193 \\
193 \\
191 \\
197\end{array}$ & $\begin{array}{l}2.65 \\
\text { 3. } 48 \\
\text { 3. } 90 \\
\text { 3. } 89 \\
\text { 4. } 73 \\
\text { 4. } 78 \\
\text { 5. } 10 \\
\text { 5. } 85 \\
6.32\end{array}$ & $\begin{array}{l}3.99 \\
5.60 \\
5.59 \\
5.95 \\
6.43 \\
6.62 \\
6.61 \\
6.48 \\
6.53\end{array}$ \\
\hline
\end{tabular}

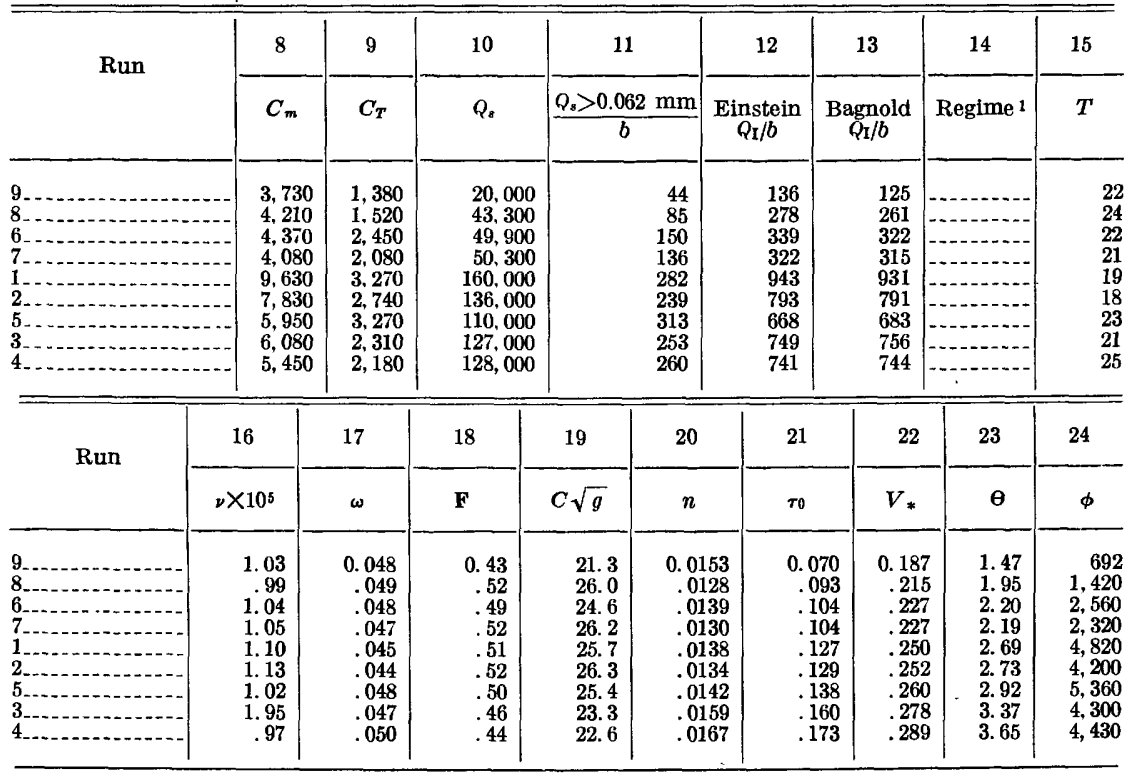

1 Not known. 


\section{LITERATURE CITED}

Bagnold, R. A., 1955, Some flume experiments on large grains but little denser than the transporting fluid, and their implications: Proc. Inst. Civil Engineers, excerpt pt. 3, p. 174-205.

___ 1956, The flow of cohesionless grains in fluids: Royal Soc. London Philos. Trans. ser. A, v. 249, p. 235-297.

- 1960, Sediment discharge and stream power-a preliminary announcement: U.S. Geol. Survey Circ. 421, 23 p.

Brooks, N. H., 1958, Mechanics of streams with movable beds of fine sands: Am. Soc. Civil Engineers Trans., v. 123, p. 526-594.

Colby, B. R., 1957, Relationship of unmeasured sediment discharge to mean velocity: Am. Geophys. Union Trans., v. 38, no. 5, p. 708-717.

Colby, B. R., and Hembree, C. H., 1955, Computations of total sediment discharge, Niobrara River near Cody, Nebraska: U.S. Geol. Survey Water-Supply Paper 1357, 187 p.

Dawdy, D. R., 1960, Depth-discharge relations: U.S. Geol. Survey Water-Supply Paper 1498b, $16 \mathrm{p}$.

Einstein, H. A., 1950, The bed-load function for sediment transportation in open channel flows: U.S. Dept. Agriculture Tech. Bull. 1026, 71 p.

Einstein, H. A., and Chien, Ning, 1958, Discussion of Brooks, 1958: Am. Soc. Civil Engineers Trans., v. 123, p. 553-562.

Federal Inter-Agency River Basin Committee, 1940, Field practice and equipment used in sampling suspended sediment, a study of methods used in measurement and analysis of sediment loads in streams: Rept. 1, $175 \mathrm{p}$.

Federal Inter-Agency River Basin Committee, 1952, The design of improved types of suspended sediment samplers, a study of methods used in measurement and analysis of sediment loads in streams: Rept. 6, $103 \mathrm{p}$.

Garde, R. J., 1959, Total sediment transport in alluvial channels: Ph. D Dissertation, Colorado State Univ., Ft. Collins, Colo.

Gilbert, G. K., 1914, Transportation of debris by running water: U.S. Geol. Survey Prof. Paper 86.

Haushild, W. L., 1960, influence of fine sediment on resistance to flow and sediment transport in alluvial channels: M.S. thesis, Colorado State Univ., Ft. Collins, Colo.

Lane, E. W., and Borland, W. M., 1954, River-bed scour during floods: Am. Soc. Civil Engineers Trans., v. 119, p. 1069-1089.

Leopold, L. B., and Maddock, T., Jr., 1953, The hydraulic geometry of stream channels and some physiographic implications: U.S. Geol. Survey Prof. Paper $252,57 \mathrm{p}$.

Leopold, L. B. and Wolman, M. G., 1957, River channel patterns-braided, meandering and straight: U.S. Geol. Survey Prof. Paper 282-B, 85 p.

Richardson, E. V., 1960, Sediment transport in alluvial channels "Examination of Bagnold's hypothesis": M.S. thesis Colorado State Univ., Ft. Collins, Colo.

Rouse, Hunter, 1946, Elementary mechanics of fluids: New York, John Wiley \& Sons, $376 \mathrm{p}$.

Simons, D. B., Richardson, E. V., and Albertson, M. L., 1961: Flume studies using medium sand $(0.45 \mathrm{~mm})$ : U.S. Geol. Survey Water-Supply Paper 1498-A. 


\section{N D E X}

[Where several page numbers appear, major references are in italic]

\begin{tabular}{|c|c|}
\hline $\mathbf{P g}$ & Page \\
\hline ntidune bed configuration & Manning's $n_{-}$ \\
\hline nold equation. & th.... \\
\hline agnold method & city \\
\hline Bagnold plot. & Median diameter, $d$. \\
\hline Bagnold theory & Median diameter of bed material \\
\hline Bagnold's total-transport and shear functions. & Modified Einstein and Bagnold, comparison \\
\hline 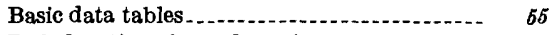 & between \\
\hline each station.... & Modified Einstein method ...... \\
\hline nges & Jikuradse's relative roughness parameter..... \\
\hline (n. & (n) \\
\hline $12,27,28,29$ & $1 \ldots$ \\
\hline 27,28 & ments.............. \\
\hline $8,36,50$ & - \\
\hline 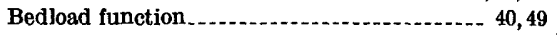 & regime.-. \\
\hline 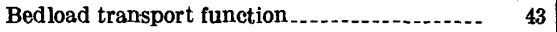 & rt. . \\
\hline - n & 8,19 \\
\hline (n) & (n) \\
\hline (n) & imating \\
\hline $3,14,28,29,34,49,54$ & 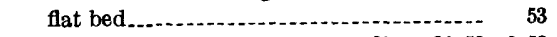 \\
\hline - & $13,19,28,29,36,50,52,53$ \\
\hline 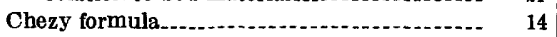 & bed \\
\hline (n) & standing wave.............. \\
\hline Computed total load. & upper $\ldots \ldots . .13,16,19,21,27,28,29,36,37,50,52$ \\
\hline
\end{tabular}

Conclusions and summary .......................

Critical shear.

Critical stress.

Data observed for stations

Definition of terms.

Depth-discharge relations

Depth-discharge relations at individual

Reynolds number effect. .................... 27

Roughness, other factors influencing......... 27 relative summary of other factors influencing ... $\quad 29$ Sand-bed channel . ............. 8, 13, 22, 27, 42, 53, 54 stations..

Depth-roughness ratio.

14 29,54

Description of reaches

Dune regime.

Einstein method.

Einstein transport function

Energy gradients for Casa Colorada reach, average.......................... 12, 35, 54

Energy slope

Fine-material load

Flow regime

Fluid shear

Froude number.

Geographic location.

Hydraulic measurements, other

Hydraulic radius.

Hydraulic radius-velocity relation

Hydraulic variables measurement

Keulegan velocity equation

Laboratory studies.

Manning's formula reach 
Page

Page

Standing wave.

Total-sediment discharge

$\mathrm{F} 8,32,40,42$

Stream velocity

Total-sediment loads.

$3,36,45,51,54$

Suspended load.

$8,40,48$

Total-sediment movement.

31

suspended-load function

Total-sediment transport .................. 36, 40,44

Suspended-load transport function ............

Suspended-sand load

size distribution

40

Total shear force

Suspended-sediment concentration ............

, Total transport function ..................... $\quad 49$

Transport function ........................ 43

Transport-shear relation

Suspended-sediment discharge

$8,9,31$

Suspended-sediment load.

Unmeasured-sediment discharge ............... 8

Suspended-sediment transport.

36,44

Tangential stress, characteristic applied

Upper-fiow regimes......................... 3

Total load

Upper-regime curves. ..................... 40

computations.......................................

3 Velocity of flow.

data.

equation

Water-surface slopes for Casa Colorada

reach.

12,54

function.

49 Width-depth ratio.

29,54

O 